Universidad de Lima

Facultad de Derecho

Carrera de Derecho

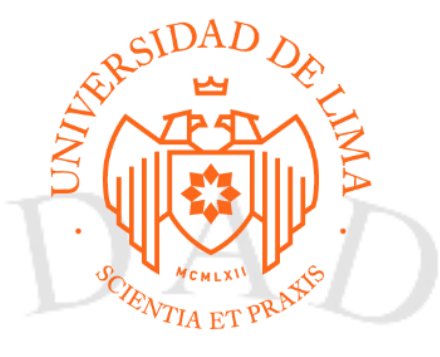

\title{
EL PROCESO DE FORMALIZACIÓN MINERA INTEGRAL EN EL PERÚ Y LA VULNERACIÓN DE LOS DERECHOS DE LOS CONCESIONARIOS MINEROS
}

Tesis para optar el Título Profesional de Abogado

\author{
Carmen Clemencia Granados Posso \\ Código 20110541
}

Asesor

Hernán Martín Torres Álvarez

Lima - Perú

Junio de 2019 


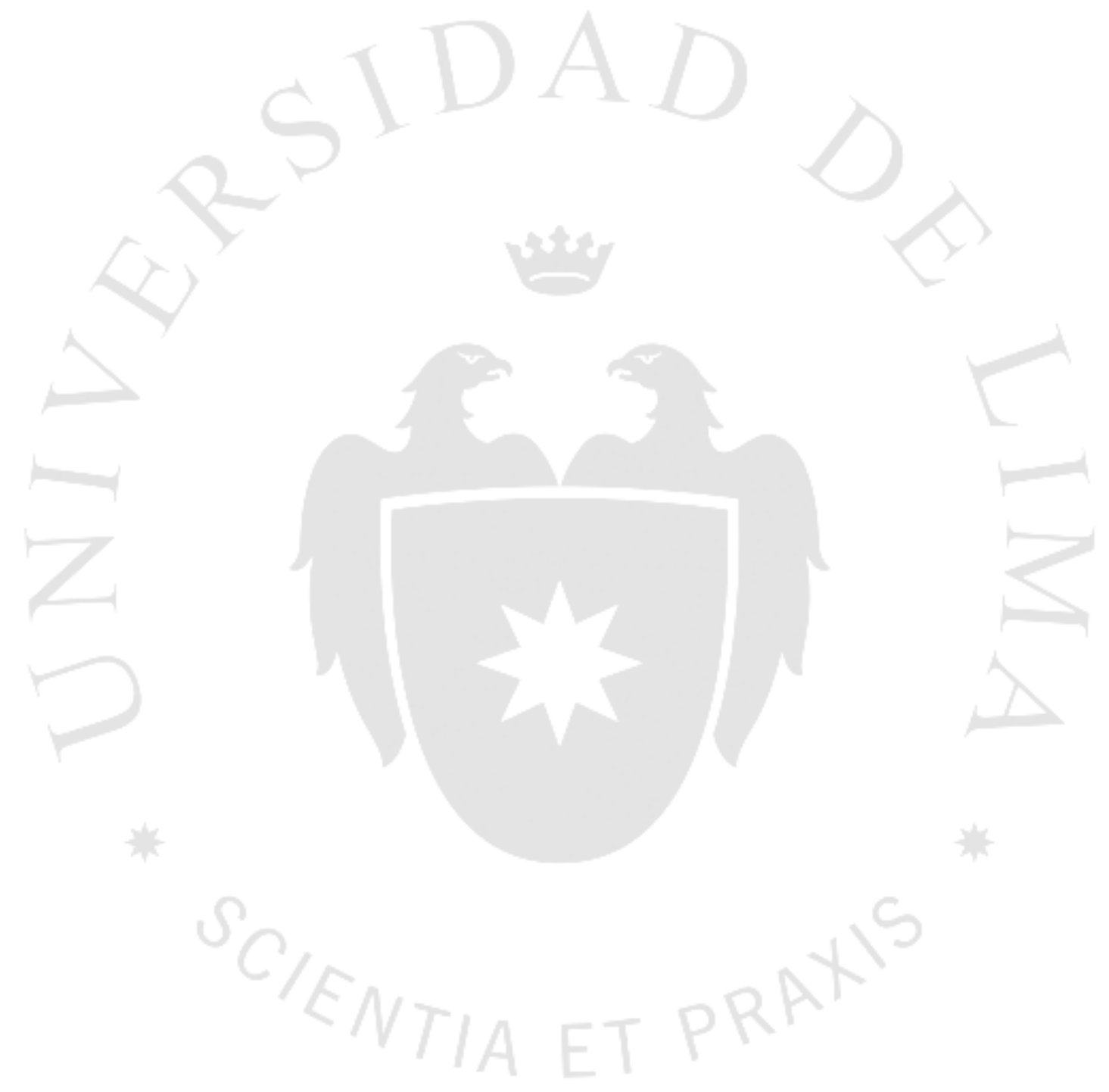




\section{EL PROCESO DE FORMALIZACIÓN}

\section{MINERA INTEGRAL EN EL PERÚ Y LA}

VULNERACIÓN DE LOS DERECHOS DE LOS

CONCESIONARIOS MINEROS 
A mis padres, por su inagotable apoyo en todos los aspectos de mi vida.

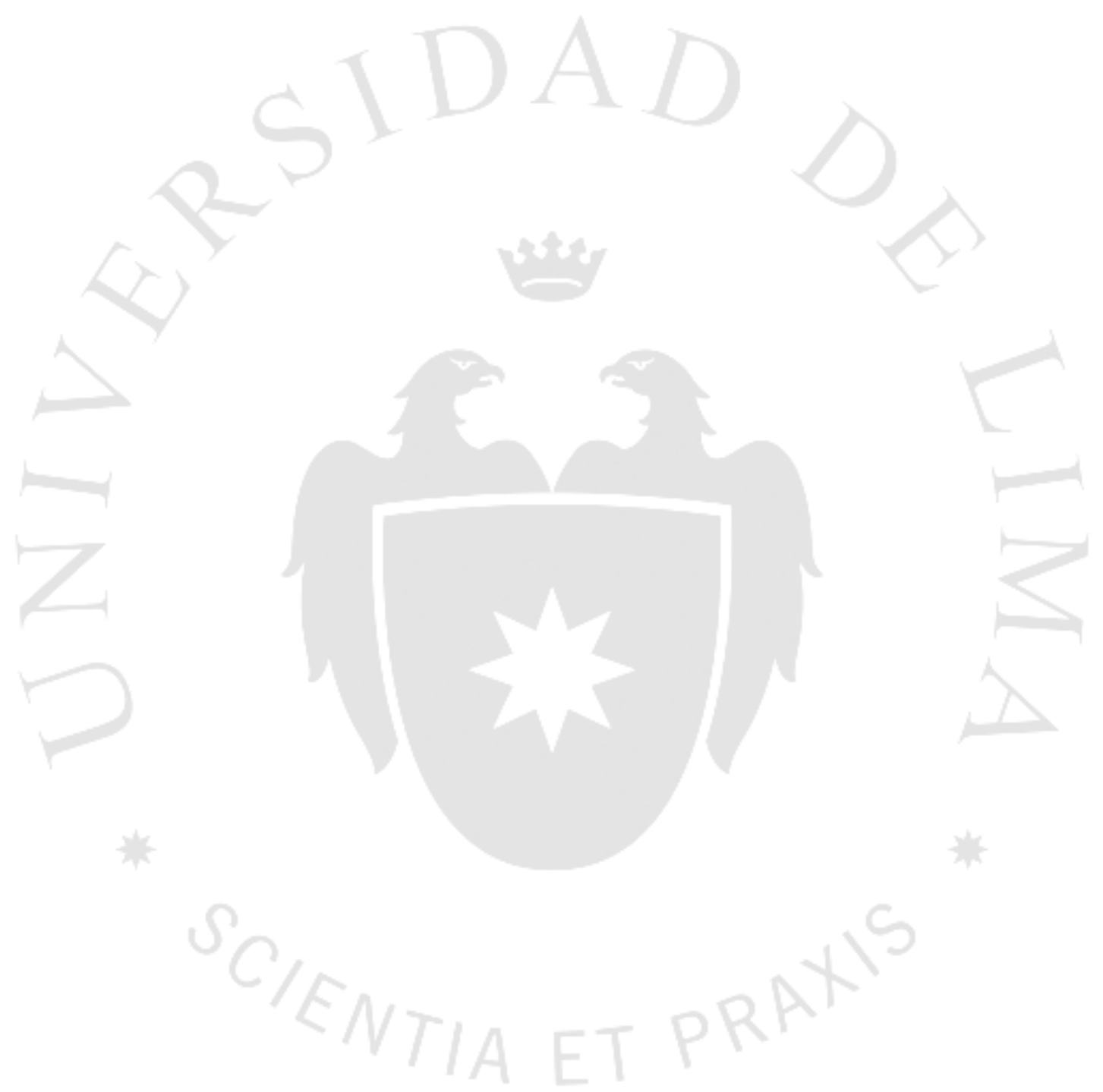




\section{TABLA DE CONTENIDO}

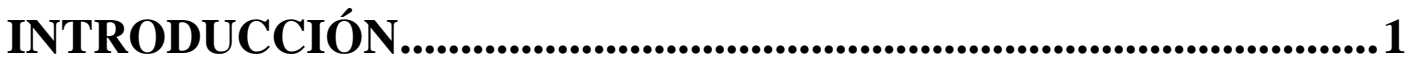

CAPÍTULO I: LA MINERÍA EN LA CONSTITUCIÓN POLÍTICA, LOS RECURSOS NATURALES Y LAS ACTIVIDADES MINERAS 5

1.1 La minería en la Constitución Política del Perú de 1993 ..........5

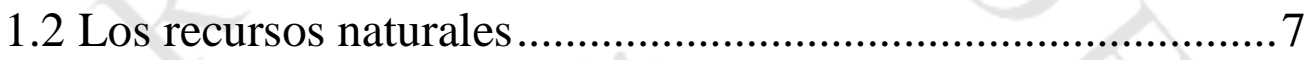

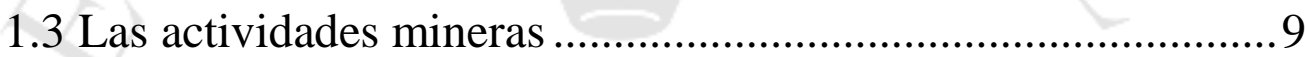

CAPÍTULO II: LA CONCESIÓN MINERA.......................................14

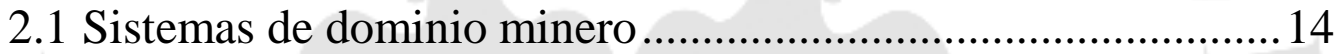

2.1.1Sistema adoptado por el Derecho Peruano ..............................16

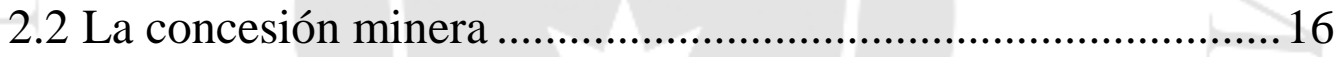

2.3 Escalas de producción en la minería...........................................21

2.4 Derechos de los concesionarios mineros ................................25

2.5 Obligaciones de los concesionarios mineros ….........................26

CAPÍTULO III: LICENCIAS, PERMISOS Y AUTORIZACIONES PARA EL INICIO DE ACTIVIDADES DE EXPLORACIÓN Y EXPLOTACIÓN

3.1 Autorización para el inicio/reinicio de las actividades de exploración y explotación 31

3.2 Acreditación de propiedad o autorización de uso del terreno superficial 34

3.3 Instrumento de Gestión Ambiental 35 
3.4 Derecho de uso de agua 40

3.5 Certificación de Inexistencia de Restos Arqueológicos .41

\section{CAPÍtUlo IV: PROCESO DE FORMALIZACIÓN MINERA INTEGRAL 44}

4.1 Productor minero artesanal y pequeño productor minero .........44

4.2 Minería ilegal y minería informal

4.3 Antecedentes del Proceso de Formalización Minera Integral ..52

4.4 Pasos del Proceso de Formalización Minera Integral 56

4.4.1 Aprobación del Instrumento de Gestión Ambiental y Fiscalización para la Formalización de Actividades de Pequeña Minería y Minería Artesanal o del Instrumento de Gestión Ambiental Correctivo. .64

4.4.2Acreditación de propiedad o autorización de uso del terreno superficial .69

4.4.3Acreditación de titularidad, contrato de cesión o contrato de explotación respecto de la concesión minera .71

4.4.4Autorización de inicio o reinicio de actividades mineras de explotación y/o beneficio de minerales, y/o título de concesión de beneficio 73

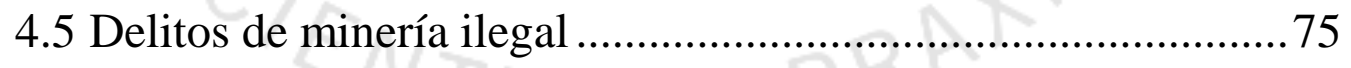

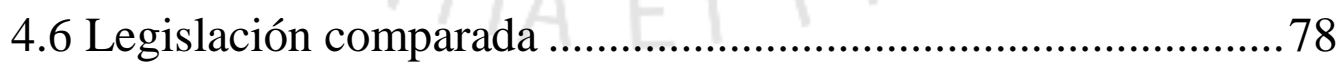

\section{CAPÍTULO V: LA VULNERACIÓN DE LOS DERECHOS DE LOS CONCESIONARIOS MINEROS. .89}

5.1 Análisis de cómo se desarrolla actividad minera en el régimen general en comparación con el Proceso de Formalización Minera Integral 89 
5.2 Análisis sobre el Proceso de Formalización Minera Integral y la vulneración que permite sobre los derechos de los concesionarios mineros. .95

5.3 Análisis sobre la facultad otorgada a los mineros informales para desarrollar actividad minera de explotación 105

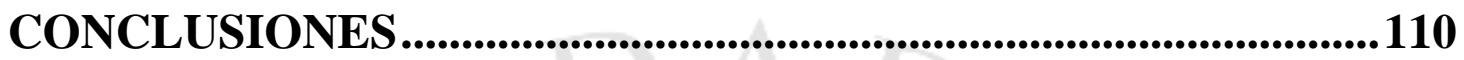

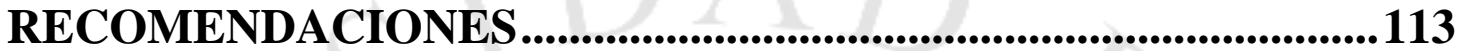

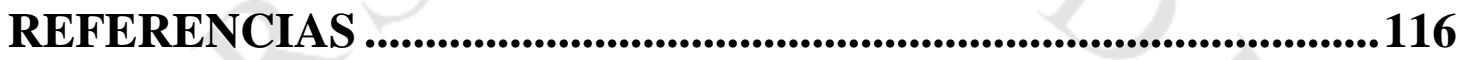

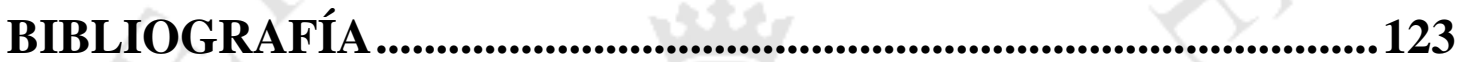




\section{ÍNDICE DE TABLAS}

Tabla 3.1 Categorización de los proyectos de acuerdo al riesgo ambiental .37

Tabla 3.2 Instrumentos de Gestión Ambiental en el régimen general.....................40

Tabla 4.1 Derechos y obligaciones mineras ........................................................ 44

Tabla 5.1 Requisitos para el ejercicio de actividad minera .................................93 


\section{ÍNDICE DE ANEXOS}

Anexo 1: Caso práctico. 126

Anexo 2: Auto Admisorio de la Acción de Amparo 136

Anexo 3: Propuesta normativa. 139

Anexo 4: El Otro Sendero... 141 


\section{ÍNDICE DE ABREVIATURAS}

TUO

Texto Único Ordenado

LGM Ley General de Minería

UTM $\quad \square$ Universal Transversal Mercator

DAC Declaración Anual Consolidada

ANA $\quad \square \quad$ Autoridad Nacional del Agua

MINEM Ministerio de Energía y Minas

PFMI Proceso de Formalización Minera Integral

REINFO Registro Integral de Formalización Minera

RUC Registro Único de Contribuyentes

CIRA Certificado de Inexistencia de Restos Arqueológicos

SEIA Sistema Nacional de Evaluación del Impacto Ambiental

EIA Estudio de Impacto Ambiental

SENACE Servicio Nacional de Certificación Ambiental para las Inversiones Sostenibles

IGA Instrumento de Gestión Ambiental

IGAC Instrumento de Gestión Ambiental Correctivo

IGAFOM Instrumento de Gestión Ambiental para la Formalización de Actividades de Pequeña Minería y Minería Artesanal

D.L. Decreto Legislativo

D.S. Decreto Supremo

RNDC Registro Nacional de Declaraciones de Compromisos

SINEFA Sistema Nacional de Evaluación y Fiscalización Ambiental

DCERH La Dirección de Calidad y Evaluación de los Recursos Hídricos

FEMA Fiscalías Especializadas en Materia Ambiental

DIREJMA Dirección Ejecutiva de Protección del Medio Ambiente de la Policía Nacional del Perú

SUNAT La Superintendencia Nacional de Aduanas y de Administración Tributaria

PROSIC Procedimiento Simplificado para el Otorgamiento del Certificado de Inexistencia de Restos Arqueológicos 


\section{INTRODUCCIÓN}

El Proceso de Formalización Minera Integral fue creado por el Estado Peruano para combatir la informalidad en la minería, la formalización de la minería artesanal y la pequeña minería busca mejorar las condiciones laborales, de salud y seguridad minera, impulsar el uso sostenible de los recursos minerales, controlar los impactos al medio ambiente, crear accesos a nuevos mercados y promover el desarrollo de las comunidades rurales que se encuentran en las áreas de influencia de la actividad minera.

Además, la formalización minera también es una medida empleada por el Estado para luchar contra la minería ilegal, actividad que afecta significativamente de manera negativa al medio ambiente, los derechos adquiridos por los concesionarios mineros, los derechos fundamentales de las personas que se encuentran en las zonas de influencia como a la integridad física y psíquica, el trabajo libre, la propiedad, la paz, gozar de un ambiente equilibrado, la libertad y la salud, debido a la práctica de las actividades de la trata de personas, el trabajo infantil e informal y la explotación sexual; además, la minería ilegal afecta la recaudación tributaria del Estado, lo cual afecta el desarrollo económico del país.

Se debe tener en cuenta que antes que el Proceso de Formalización Minera Integral entrara en vigencia en el año 2016 mediante el Decreto Legislativo $N^{\circ} 1293$, existieron otros procesos distintos pero con la misma finalidad de formalizar la minería ilegal, el primero fue el proceso de formalización del D.L. № 1105.

Las inscripciones de los mineros informales en el REINFO dan inicio al Proceso de Formalización Minera Integral, para formar parte deben desarrollar actividad minera de explotación como pequeños productores o productores artesanales. Una vez iniciado el proceso, los mineros informales deben cumplir con acreditar los requisitos señalados en el artículo 3 del D.L. № 1336 para culminarlo de manera satisfactoria, de lograrlo, la 
Dirección Regional de Energía competente emite la autorización de inicio o reinicio de actividades mineras, y declara a la persona natural o persona jurídica un minero formal.

El problema radica en que algunos mineros informales utilizan el Proceso de Formalización Minera Integral como una vía para realizar actividad minera de explotación sin haber acreditado, entre otros requisitos legales, un contrato de cesión o explotación minera con los titulares mineros del área dónde extraen minerales; sobre todo en los casos donde son conscientes de que no hay probabilidades reales de que puedan culminar satisfactoriamente dicho proceso de formalización, por lo que aprovechan la vigencia del mismo para explotar y comercializar recursos minerales que no son de su propiedad.

Ante eso, se planteó como pregunta principal: ¿De qué manera el Proceso de Formalización Minera Integral vulnera los derechos fundamentales de los titulares de las concesiones mineras frente a su mal uso por parte de los mineros informales?

Como respuesta a la anterior pregunta, se plantea la hipótesis de que el Proceso de Formalización Minera Integral vulnera de manera significativa los derechos fundamentales de los titulares de las concesiones mineras debido al mal uso por parte de los mineros informales; siendo el objetivo principal del presente trabajo de investigación determinar de qué manera ocurre esta afectación negativa.

Los objetivos secundarios son exponer los temas relacionados a la minería desde un marco general como la Constitución Política hasta las normas jurídicas sobre el proceso de formalización más específicas. Asimismo, se busca desarrollar el Proceso de Formalización Minera Integral para una mejor comprensión y análisis del mismo: sus antecedentes y evolución, la inscripción en el REINFO, los pasos y requisitos que se deben completar según la legislación vigente, los derechos y obligaciones que genera, como está regulada la participación de los titulares de las concesiones mineras, como se ven afectados y determinar si son necesarias modificaciones del modelo actual.

La presente investigación se justifica porque es conveniente estudiar el Proceso de Formalización Minera Integral debido a que impacta a un sector económicamente muy importante para el país como lo es el sector minero; ante lo cual, en caso de existir errores 
que permitan la vulneración de los derechos de los concesionarios mineros lo correcto es buscar una solución. Los agentes interesados con los resultados son los mineros ilegales e informales, los titulares de las concesiones mineras, el MINEM y las demás entidades del Estado relacionadas a las actividades mineras.

En el aspecto metodológico, el tipo de investigación de la presente tesis es cualitativo porque trabaja con un reducido números de casos, analiza el contexto, la estructura y describe el proceso de formalización actual. Además, el diseño de investigación es no experimental; el método de estudio a seguir es el deductivo, que parte desde los conceptos más generales del tema a tratar hasta los más particulares, en este caso, desde lo que indica la Constitución Política sobre los recursos naturales, hasta el D.L. $\mathrm{N}^{\mathrm{o}} 1336$ y sus normas complementarias.

El proceso de formalización minera es relativamente nuevo, se creó en el año 2012 por D.L. $\mathrm{N}^{\circ} 1105$, razón por la cual el número de trabajos de investigación, libros o publicaciones de artículos de revistas sobre el tema es muy reducido; ante eso, las fuentes utilizadas para la recolección de información son las normas jurídicas mineras, en especial las que regulan el Proceso de Formalización Minera Integral, los artículos de periódicos nacionales, los casos prácticos y las investigaciones realizadas por organizaciones ambientales.

El presente trabajo de investigación se estructura en cinco capítulos, el Capítulo I comprende los aspectos más generales, lo que señala la Constitución Política y las leyes sobre los recursos naturales y el uso sostenible de los mismos; además, cuáles son las diferentes actividades mineras, tanto las que requieren de una concesión minera como las que no.

El Capítulo II comprende los Sistemas de Dominio Mineros y el sistema adoptado por el Derecho Minero Peruano, todo lo referente a la concesión minera: qué es, cuales son sus características, los derechos y obligaciones que vienen con ella - reconocidos tanto por el TUO de la Ley General de Minería y el Reglamento de Procedimientos Mineros como por el Código Civil - además de los procedimientos para su tramitación y cuales son las autoridades competentes. 
El Capítulo III desarrolla las autorizaciones, licencias y permisos administrativos necesarios para realizar actividad minera - además de la concesión minera que es solo el título habilitante - cómo se tramitan y ante que entidades del Estado. Por ejemplo: el IGA, el Derecho de uso de agua, el CIRA, la Acreditación de Propiedad o Autorización de Uso del Terreno Superficial y Autorización para el inicio o reinicio de las Actividades de Exploración o Explotación.

El Capítulo IV comprende todo lo relacionado al Proceso de Formalización Minera Integral; como introducción al tema la acreditación de la condición de Productor Minero Artesanal o Pequeño Productor Minero, las definiciones y diferencias entre la minería ilegal y la minería informal; luego, los antecedentes de los procesos de formalización hasta los actuales pasos y requisitos vigentes para culminar dicho proceso, y por último los delitos de minería ilegal.

El Capítulo V analiza el Proceso de Formalización Minera Integral, como se desarrolla en comparación al régimen general, las condiciones que genera para que los mineros informales puedan vulnerar los derechos adquiridos por los concesionarios mineros durante la vigencia del proceso, los efectos generados por la simplificación y modificación de los requisitos; además de las facultades que otorga la inscripción en el REINFO y un análisis sobre la propiedad de los recursos minerales según la normativa vigente.

Por último, se desarrollan las conclusiones obtenidas del presente trabajo de investigación y ante ellas, se exponen las recomendaciones para las modificaciones necesarias al Proceso de Formalización Minera Integral. 


\section{CAPÍTULO I: LA MINERÍA EN LA CONSTITUCIÓN POLÍTICA, LOS RECURSOS NATURALES Y LAS ACTIVIDADES MINERAS}

\subsection{La minería en la Constitución Política del Perú de 1993}

La minería se encuentra regulada en la Constitución Política (1993) en el Artículo 66:

"Los recursos naturales, renovables y no renovables, son patrimonio de la Nación.

El Estado es soberano en su aprovechamiento. Por ley orgánica se fijan las condiciones de su utilización y de su otorgamiento a particulares. La concesión otorga a su titular un derecho real, sujeto a dicha norma legal"'.

Además, el artículo 67 de la Carta Magna señala que el "Estado determina la política nacional del ambiente y promueve el uso sostenible de sus recursos naturales”.

El concepto de Nación guarda relación con el territorio y la población Peruana, toma en cuenta los aspectos sociales y culturales, es por ello que la Constitución Política deja en claro que el correcto uso de los recursos naturales debe tener un impacto positivo en todos los peruanos y en sus futuras generaciones, razón por la cual es considerado patrimonio de la Nación.

Al determinar que el Estado es soberano indica que tiene la facultad de decidir bajo qué condiciones pueden aprovecharse los recursos naturales, así como administrarlos de la manera en que considere correcta. La concesión minera otorga un derecho real sobre el cual se posee una influencia directa e inmediata, además de la facultad de oponerle dicho derecho a terceros.

La Política Nacional del Ambiente la determina el Estado cumpliendo con lo pactado en el articulo 67 de la Constitución Política, se desarrolla mediante el pacto de objetivos y las acciones que deben realizar los Gobiernos Regionales y Locales, así como el Gobierno Nacional, para alcanzarlos. 
Uno de los objetivos principales de la Política Nacional del Ambiente es lograr el correcto aprovechamiento del patrimonio natural del Perú y promover su conservación respetando la equidad, la eficiencia y priorizando el bienestar social (Decreto Supremo No 012-2009-MINAM, 2009).

Continuando con la segunda parte del articulo 67 de la Constitución Política el Estado "promueve el uso sostenible de sus recursos naturales", lo cual se logra cuidando el impacto generado por la extracción y la explotación de dichos recursos. A su vez, debe completar las necesidades de la población sin comprometer a las siguientes generaciones, teniendo especial cuidado con los recursos naturales no renovables.

Además, dentro del Capítulo XIV de la Constitución Política (1993) que abarca la descentralización en el país, vuelve a aparecer la minería en el inciso 7) del artículo 192, señala que los Gobierno Regionales son los encargados de promover y ordenar las actividades mineras; así como también para otros sectores como agricultura, turismo, energía, entre otros.

La minería es una más de las diversas actividades que los gobiernos regionales están en obligación de promover en beneficio de toda su región, lo cual acelera el proceso de descentralización e impacta positivamente en todo el país.

Por último, la Constitución Política (1993) que regula la propiedad hace mención a la minería una vez más en el artículo 71, el cual impide a los extranjeros obtener o tener minas dentro de los cincuenta kilómetros de las fronteras, bajo responsabilidad de perder dicho derecho en caso de no cumplir con el mandato legal.

Dejaba como única excepción la necesidad pública que debía ser expresada mediante Decreto Supremo; dicho artículo fue creado dentro de un contexto social y político distinto al actual y era una manera de proteger la seguridad del país; sin embargo, dentro del presente mundo capitalista las inversiones extranjeras son una gran oportunidad de negocios. 


\subsection{Los recursos naturales}

La naturaleza está relacionada con el universo, el planeta Tierra, la atmósfera, los seres vivos que habitan en ella, los recursos naturales y la manera en que coexisten todos estos elementos. En su proceso de creación no ha intervenido ningún ser humano, es decir, toda su evolución se ha desarrollado de manera natural.

“Los recursos naturales son los bienes que se ubican en la naturaleza, de los cuales el género humano se vale para saciar sus necesidades, pero todavía en gran parte no han sido objeto de transformación por parte de él” (Andía Chávez, 2010, pág. 16).

El Perú cuenta con una inmensa cantidad de recursos naturales, además de destacar por la calidad de los mismos; asimismo, cuenta con valiosos minerales metálicos que lo sitúan como uno de los principales productores en todo el mundo (Ministerio de Agricultura y Riego, 2015).

La Ley $N^{\circ} 26821$ es la norma que siguiendo los lineamientos de la Constitución Política y las normas internacional ratificadas, regula todo lo concerniente al uso sostenible de los recursos naturales, incluyendo objetivos, restricciones y los procedimientos para el otorgamiento de los mismos a los privados.

El artículo 2 determina que su principal objetivo es el siguiente:

"La presente Ley Orgánica tiene como objetivo promover y regular el aprovechamiento sostenible de los recursos naturales, renovables y no renovables, estableciendo un marco adecuado para el fomento a la inversión, procurando un equilibrio dinámico entre el crecimiento económico, la conservación de los recursos naturales y del ambiente y el desarrollo integral de la persona humana" (Ley $\left.N^{\circ} 26821,1997\right)$.

El artículo anterior hace la distinción entre los recursos naturales renovables y los no renovables. Los primeros, son los recursos que de manera natural se pueden regenerar siempre y cuando no sean usados de manera excesiva, algunos ejemplos son el agua, el aire, la radiación solar y el viento. En cambio, los segundos son los que se encuentran en 
cantidades limitadas en el planeta, no pueden regenerarse de manera natural ni con ayuda de la intervención humana, algunos ejemplos son los minerales, el petróleo y el gas.

De manera más específica, los recursos naturales son todos los componentes que se encuentran en la naturaleza y que pueden ser utilizados por las personas de manera favorable y que poseen un valor monetario en el mercado. La Ley $\mathrm{N}^{\circ} 26821$ en su artículo 3 regula los tipos existentes de recursos naturales, siendo algunos de ellos los siguientes: agua, suelo, la diversidad biológica, los recursos genéticos, el aire, eólicos, solares, geotérmicos, la atmósfera y siendo de vital importancia para el desarrollo del presente trabajo de investigación: los minerales (Ley No 26821, 1997).

Existen dos momentos para determinar quién es el propietario de los recursos naturales, en primer lugar, cuándo se encuentran en su fuente y en segundo lugar, cuándo ya fueron extraídos. En el primer caso, los recursos naturales que se mantienen en su lugar de origen son Patrimonio de la Nación; en cambio, cuando son extraídos, sus frutos y productos pertenecen a los particulares a los cuales fueron concedidos.

Sobre los recursos minerales, el artículo II del Título Preliminar del TUO de la LGM, señala que:

"Todos los recursos minerales pertenecen al Estado, cuya propiedad es inalienable e imprescriptible.

El Estado evalúa y preserva los recursos naturales, debiendo para ello desarrollar un sistema de información básica para el fomento de la inversión; norma la actividad minera a nivel nacional y la fiscaliza de acuerdo con el principio básico de simplificación administrativa.

El aprovechamiento de los recursos minerales se realiza a través de la actividad empresarial del Estado y de los particulares, mediante el régimen de concesiones”.

El Estado promueve el uso sostenible de los recursos naturales a través de leyes especiales, de esta manera se abarcan los temas específicos que necesita cada recurso natural debido a sus características; además, apoya con la construcción de la infraestructura necesaria y el fomento de información. Todo lo anteriormente 
mencionado se debe desarrollar en perfecta sincronización con el interés común de la Nación y las leyes generales.

El uso de los recursos naturales debe realizarse de manera sostenible; para los renovables esto significa darle un uso racional teniendo en consideración la capacidad de renovación que posee cada recurso natural, con el debido cuidado de no sobrepasarla. En cambio, para los no renovables, el uso sostenible se consigue con una explotación limitada y minimizando los impactos no positivos en el medio ambiente.

El artículo 20 de la Ley $N^{o} 26821$ señala lo siguiente sobre la retribución económica:

Todo aprovechamiento de recursos naturales por parte de particulares da lugar a una retribución económica que se determina por criterios económicos, sociales y ambientales. Ya sea como contraprestación, derecho de otorgamiento o derecho de vigencia del título que contiene el derecho, establecidos por las leyes especiales (Ley No 26821, 1997).

\subsection{Las actividades mineras}

La actividades mineras abarcan más ámbitos de trabajo que solo la explotación minera, de manera correcta, dicha afirmación nos señala que las actividades mineras entran a desarrollarse desde antes del conocimiento certero de la existencia de minerales hasta después de su agotamiento. En el primer caso, con la actividad de cateo; y en el segundo supuesto, con la actividad de cierre.

Las actividades mineras se dividen en dos grupos: las actividades libres, es decir, las que no necesitan de una concesión minera para desarrollarse, y las que se ejecutan bajo el sistema de concesiones. Las que se encuentran en el primer grupo son: el cateo, la prospección y la comercialización. En cambio, las del segundo grupo son: la exploración, explotación, transporte minero, beneficio y labor general. Pueden realizarlas tanto personas naturales como jurídicas, así sean nacionales o no. 
Empezando con las actividades libres, el cateo tiene como finalidad la búsqueda de minerales mediante indicaciones físicas y químicas básicas. No requiere de una autorización por parte del Estado, razón por la cual es considerada una actividad libre.

La prospección de igual manera busca determinar áreas de posible mineralización mediante el uso de técnicas físicas y químicas pero implicando un estudio más profundo. Ambas actividades persiguen el mismo fin: el descubrimiento de minerales, la diferencia radica en la complejidad de los métodos aplicados al desarrollarse la búsqueda.

Ambas son actividades libres a lo largo de todo el territorio del Perú; sin embargo, el artículo 2 del TUO de la LGM les establece las siguientes limitaciones:

El cateo y la prospección son libres en todo el territorio nacional. Estas actividades no podrán efectuarse por terceros en áreas donde existan concesiones mineras, áreas de no admisión de denuncios y terrenos cercados o cultivados, salvo previo permiso escrito de su titular o propietario, según sea el caso.

Es prohibido el cateo y la prospección en zonas urbanas o de expansión urbana, en zonas reservadas para la defensa nacional, en zonas arqueológicas y sobre bienes de uso público; salvo autorización previa de la entidad competente. (Decreto Supremo Nº14-92-EM, 1992).

La última actividad minera libre es la comercialización, la cual puede ser definida como la venta de minerales y metales en los mercados tanto internos como externos. Al realizar cualquier compra de minerales se necesita de una diligencia alta para determinar el origen de los mismos, ya que el comprador está sujeto a la responsabilidad correspondiente en caso el mineral provenga de una fuente no legal.

Además, "la compra hecha a un concesionario otorga al comprador el privilegio de estar exento de la acción reivindicatoria respecto de los minerales que le fueron vendidos por el concesionario“" (Belaunde Moreyra, 2011, pág. 68), esto se explica gracias a que el artículo 4 del TUO de la LGM promueve la compra a personas autorizadas con la no reivindicación de los productos minerales. 
Sobre el valor monetario a pactar sobre los minerales, el artículo 28 determina lo siguiente:

Los precios de venta y/o tarifas por servicios de tratamiento y/o refinación de los productos minerales serán los correspondientes para cada producto, de acuerdo a cotizaciones internacionales representativas y dentro de las modalidades generales de las transacciones internacionales (Decreto Supremo No 014-92-EM, 1992).

Empezando con la concesión exploración, el artículo 8 del TUO de la LGM señala que la exploración es la actividad minera proclive a probar las extensiones, disposiciones, características mineralógicas, reservas y valores de los minerales.

Esta actividad entra en acción después de haberse concluido con las actividades de cateo y prospección, en otras palabras, es la continuación natural debido a que se explora en una zona con indicios claros de poseer minerales. "No se trata de descubrir un yacimiento, sino de evaluar un yacimiento ya descubierto“ (García Montufar \& Franciskovic Ingunza, 1999, pág. 5).

Como una de las primeras actividades mineras, la exploración tiene como objetivo evaluar y determinar si un yacimiento minero es susceptible de otorgar ganancias económicas en un futuro, porque si no se puede considerar un negocio rentable no se debería pasar al siguiente paso: la explotación minera.

La explotación es la acción de extraer los minerales que se encuentran en los yacimientos mineros. La concesión otorga a su titular el derecho de explotar los yacimientos mineros, los cuales una vez extraídos pasan a formar parte de su propiedad. Por ende, cuando los recursos minerales son explotados de manera ilegal, estos siguen perteneciendo al Estado Peruano.

No se pueden ignorar las consecuencias ambientales de la explotación minera, (Andía Chávez, 2010) señala que:

Los procesos de extracción mineral generan grandes cantidades de desechos, emanaciones de polvos, que se convierten en un alto potencial contaminante. Que 
afectan los cursos de agua y se crea potenciales impactos deletéreos sobre la flora fauna circundante y de la biodiversidad en general.

La actividad minera de explotación es altamente contaminante, es por ello que para ejércela es indispensable contar con el IGA que corresponda, además de cumplir con las demás obligaciones ambientales, bajo responsabilidad de ser fiscalizados y sancionados.

Continuando con las actividades mineras ejercidas bajo el sistema de concesiones, “La Labor general es toda actividad minera que presta servicios auxiliares, tales como ventilación, desagüe, izaje o extracción a dos o más concesiones de distintos concesionarios“, conforme señala el artículo 19 del TUO de la LGM.

En el último supuesto, "No podrá hablarse de superposición, porque la concesión de labor general es de distinta naturaleza. Estos servicios auxiliares no afectan a las concesiones de diferentes naturalezas ubicadas en el área de influencia, muy por el contrario, las benefician“ (Baldeón Ríos, 2016, págs. 192-193).

Los minerales que han sido extraídos a la superficie no se encuentran en estado puro, sino que están mezclados con materiales estériles o rocas tal y como se encuentran en los yacimientos mineros. "La labor minera de separación del mineral económicamente explotable de los desmontes, se le denomina beneficio“" (Baldeón Ríos, 2016, pág. 193). Esta labor se realiza mediante procesos físicos y químicos, es importante recalcar que la concesión de beneficio no convierte el mineral en una sustancia nueva, simplemente cumple con la función de purificarlo.

La última actividad minera que necesita de una concesión minera es el transporte minero, el artículo veintidós del TUO de la LGM determina que es todo sistema que se utiliza para el transporte masivo constante de productos minerales, por métodos no tradicionales. Podrán ser estos fajas transportadoras; tuberías o cable carriles.

(García Montufar \& Franciskovic Ingunza, 1999) determinan cuales son las actividades que necesitan de una concesión de transporte para poder operar: 
La actividad de transporte minero requiere solicitar una concesión de transporte minero si concurren las siguientes circunstancias: 1) Que el transporte o acarreo de minerales se haga de un centro minero a un puerto o a una planta de beneficio, o a una refinería. 2) Que el acarreo de minerales sea masivo y continuo. 3) Que para el acarreo de minerales se empleen fajas transportadoras, tuberías o cables carriles (pág. 26). 


\section{CAPÍTULO II: LA CONCESIÓN MINERA}

\subsection{Sistemas de dominio minero}

¿Quién es el propietario de los recursos naturales? La respuesta varía dependiendo que cual es el sistema de dominio adoptado en un determinado país. Los sistemas de dominio minero se dividen principalmente en dos grupos: los sistemas que no alejan el dominio originario del derivado, los cuales le atribuyen la propiedad como un todo; y los sistemas que mantienen separado el dominio originario del derivado y consideran a aquel como de nadie. En el primer grupo se encuentran el sistema de accesión, el sistema dominalista y el sistema socialista. En cambio, forman parte del segundo grupo el sistema de ocupación y el sistema res nullius (Baldeón Ríos, 2016, pág. 211).

Empezando por el sistema de accesión o también conocido como fundiario, se considera que todos los recursos naturales que se mantienen en el suelo o subsuelo, debido al principio de accesión, pertenecen de igual manera al propietario del terreno superficial.

Dentro de las facultades que posee el propietario del terreno superficial están las siguientes:

"Podrá directamente ejecutar o negociar con terceros la explotación o no de los minerales según las reglas civiles de la propiedad y el mercado. Dicho de otro modo, consolida y reconoce en un solo titular (el del terreno) todos los derechos, sobre la base del principio general del Derecho que dispone que lo accesorio sigue la suerte de lo principal” (Salazar Niño, 2015, pág. 364).

El sistema dominalista reconoce que los recursos naturales que se encuentran en el subsuelo son un patrimonio distinto del suelo o la superficie, y que se encuentran bajo el dominio del Estado. Estos yacimientos pueden ser otorgados a los particulares mediante el régimen de concesiones. 
Como señala (Salazar Niño, 2015), el Estado no puede hacer lo que desee con el dominio que posee sobre los recursos naturales:

"Los límites a esta soberanía del Estado son las normas jurídicas que dispone para el otorgamiento y la correcta gestión de los recursos naturales, que a su vez actúan como un marco de garantía para los privados que ingresan al sistema de aprovechamiento de los recursos mediante las concesiones" (pág. 367).

En el sistema socialista el dominio originario de los yacimientos pertenece al Estado y se separa la superficie del recurso mineral (García Montufar \& Franciskovic Ingunza, 1999, pág. 44). La diferencia del sistema socialista con el sistema dominalista, radica en que el primero rechaza la posibilidad de la intervención privada, solo el estado cuenta con la facultad para beneficiarse del uso de los recursos naturales.

No debe confundirse el presente sistema de dominio con la nacionalización, el cual es un acto estatal, (García Montufar \& Franciskovic Ingunza, 1999) lo explican de la siguiente manera:

"La nacionalización se define como el acto estatal, derivado de la competencia del legislador, que sustrae a la iniciativa o propiedad privada, bienes, empresas o una actividad, medios de producción o de cambio para asignarlos al Estado u organismos creados por él apoyado en razones de utilidad pública o de interés nacional” (pág. 44).

Entrando al segundo grupo, el sistema de la ocupación considera a las minas como cosa de nadie, por lo cual consigna el dominio de la mina al primer ocupante de la misma, de esta manera, será su descubridor quien tendrá derecho a explotarlo mediante el trabajo minero (Cucho Mendoza, 1999, pág. 8).

Se le entrega el dominio de las minas a aquel que las descubre y trabaja, y ello no implica entonces el establecimiento de una concesión minera alguna ni transferencia de propiedad por parte del estado (Gamarra Barrantes, 2009, pág. 51).

Por último, en el sistema res nullius las minas no pertenecen a nadie y el Estado le concede los derechos sobre los yacimientos mineros a las personas que concentran las 
mejores condiciones para efectuar la explotación más adecuada para la colectividad (Lira Ovalle, 1998, pág. 39).

\subsubsection{Sistema adoptado por el Derecho Peruano}

Luego de exponer los sistemas de dominio que existen cabe señalar que la legislación Peruana adopta el sistema Dominalista, lo cual está regulado en el artículo 66 de la Constitución Política (1993):

"Los recursos naturales, renovables y no renovables, son patrimonio de la Nación.

El Estado es soberano en su aprovechamiento. Por ley orgánica se fijan las condiciones de su utilización y de su otorgamiento a particulares. La concesión otorga a su titular un derecho real, sujeto a dicha norma legal".

Como se citó en (Baldeón Ríos, 2016), el discurso pronunciado por el Doctor Arturo Osores nos dice lo siguiente:

Las normas constitucionales hacen suyo el sistema del dominio eminente de los recursos minerales que corresponden a la nación, personificada por el Estado Peruano, y el otorgamiento a los particulares para su aprovechamiento sostenible es a través de un acto administrativo: la concesión minera, que otorga a su titular el dominio útil de la sustancia mineral concedida (pág. 222).

En el Perú los recursos naturales, dentro de los cuales están incluidos los recursos minerales, son propiedad de la Nación. El Estado en imagen de este y para el beneficio de todos los peruanos, permite mediante la concesión minera que se le otorguen derechos a los privados, regulando las condiciones y obligaciones a través de leyes orgánicas.

\subsection{La concesión minera}

La concesión minera es un acto administrativo, unilateral y reglado, por el cual el Estado constituye a favor de los privados la facultad de realizar actividades mineras y, como derecho, otorga un derecho real (Baldeón Ríos, 2016, pág. 239). Este acto lo realiza el Estado en uso de la soberanía que posee sobre los recursos naturales, en este caso específicamente sobre los minerales, en busca de su correcto aprovechamiento. 
De la manera más simple, se puede afirmar lo siguiente de la concesión minera (Belaunde Moreyra, 2011):

"Cuando hablamos de acto jurídico administrativo nos referimos a una manifestación de voluntad de un ente público que crea, extingue o modifica derechos a favor de los particulares pero también, en ciertas circunstancias, a favor del propio Estado o de organismos vinculados al Estado" (pág. 55).

La concesión minera cuenta con características distintas en comparación a otros actos administrativos, como la licencia, la autorización y el permiso.

"La licencia es el acto administrativo por medio del cual se crea un derecho a favor de quien se otorga; se transfiere el ejercicio de determinadas actividades que en principio estuvieron reservadas a la administración a la esfera privada" (Forno Castro, 2009, pág. 53). La licencia es intuito personae, es intransferible salvo anuencia de la autoridad; en cambio, la concesión minera no se otorga en atención a la persona, es objeto de transferencia por acto inter vivos o mortis causa; además, la licencia faculta el ejercicio de una actividad privada, mientras que la concesión minera faculta el ejercicio de un actividad privada sobre los minerales de dominio eminente del Estado (Baldeón Ríos, 2016, pág. 266).

Continuando con los actos administrativos, como señala Bermejo Vera:

La autorización consiste en la remoción de límites para el ejercicio de derechos de particulares; es decir, algunos derechos subjetivos necesitan para ser ejercidos en plenitud, el permiso de la administración pública correspondiente quien antes de otorgarlo, comprueba que el derecho preexistente se va a ejercitar de manera adecuada, como se citó en (Forno Castro, 2009, pág. 53).

Por tanto, con "la autorización el derecho preexistente tiene como fuente una norma jurídica atributiva que se potencializa, se habilita y delimita con dicho acto administrativo; en cambio, en la concesión minera no existe un derecho preexistente por potencializar o delimitar” (Baldeón Ríos, 2016, pág. 265).

El permiso es un acto administrativo por el cual se faculta a una persona el ejercicio de un derecho, que en un inicio se encontraba impedido por las leyes (Forno 
Castro, 2009, pág. 53). El permiso es una excepción respecto de una prohibición; en cambio, la concesión minera constituye un nuevo derecho para el privado, el cual está sujeto a la aprobación de la administración y al cumplimiento de requisitos legales, bajo responsabilidad de caer en caducidad por el incumplimiento de estas condiciones (Baldeón Ríos, 2016, pág. 263).

La concesión minera cuenta con determinadas características que la hacen única y la distinguen de los actos administrativos mencionados anteriormente. Como primera característica, es un acto legal, debido a que las leyes especiales fijan las condiciones para su utilización, la posición que asume el Estado y la manera en que se otorgan derechos a los particulares.

Como otra característica, la concesión minera es un acto formal, así lo señala (Baldeón Ríos, 2016) de la siguiente manera:

"Las reglas son las formalidades del acto, en el sentido de que están concebidas como garantía del ciudadano y que deben ser aplicadas e interpretadas. No se trata, pues de meras cuestiones de forma, sino de formalidades que deben ser cumplidas en resguardo de la legalidad" (pág. 242).

A su vez, una de las características más compleja es que la concesión minera es un derecho real; esto se encuentra regulado en el artículo 10 del (Decreto Supremo $N^{\circ}$ 014-92-EM, 1992):

"La concesión minera otorga a su titular un derecho real, consistente en la suma de los atributos que esta Ley reconoce al concesionario. Las concesiones son irrevocables, en tanto el titular cumpla las obligaciones que esta ley exige para mantener su vigencia".

El artículo 4 de la Ley $\mathrm{N}^{\circ} 26821$ determina que los "los frutos y productos de los recursos naturales" que se adquieren de acuerdo a lo que establecen las leyes especiales "son del dominio de los titulares de los derechos concedidos sobre ellos".

Para comprender mejor el artículo anterior, veamos las definiciones que nos ofrece el Código Civil, en el artículo 890 regula los frutos como "los provechos 
renovables que produce un bien, sin que se altere ni disminuya su sustancia", lo propio hace con los productos en el artículo 894, al señalar que son "los provechos no renovables que se extraen de un bien".

Ambos artículos mencionados anteriormente le atribuyen una característica más a la concesión minera, siendo esta su calidad de irrevocable. La segunda parte del artículo 10 del TUO de la Ley General de Minera señala que "las concesiones son irrevocables, en tanto el titular cumpla las obligaciones que esta ley exige para mantener su vigencia".

El artículo 9 del TUO de la Ley General de Minería regula lo siguiente:

La concesión minera otorga a su titular el derecho a la exploración y explotación de los recursos minerales concedidos, que se encuentren dentro de un sólido de profundidad indefinida, referidos a coordenadas Universal Transversal Mercator (UTM). La concesión minera es un inmueble distinto y separado del predio donde se encuentre ubicada.

Las partes integrantes y accesorias de la concesión minera siguen su condición de inmueble aunque se ubiquen fuera de su perímetro, salvo que por contrato se pacte la diferenciación de las accesorias. Son partes integrantes de la concesión minera, las labores ejecutadas tendentes al aprovechamiento de tales sustancias. Son partes accesorias, todos los bienes de propiedad del concesionario que estén aplicados de modo permanente al fin económico de la concesión (Decreto Supremo No 014-92-EM, 1992).

Del presente artículo podemos sacar que en una concesión para la explotación de minerales no se determina un límite en cuanto a la profundidad necesaria para conseguirlos, además que la superficie cuenta con una unidad básica de medida.

Como indica el artículo 11 del TUO de Minería: "La unidad básica de medida superficial de la concesión minera es una figura geométrica, delimitada por coordenadas UTM, con una extensión de 100 hectáreas, según el Sistema de Cuadrículas que oficializará el Ministerio de Energía y Minas". El mismo artículo determina que las concesiones son concedidas en tamaño de 100 a 1,000 hectáreas, con la excepción del 
dominio marítimo, donde podrán ser de hasta 10,000 hectáreas (Decreto Supremo No 014-92-EM, 1992).

De regreso al segundo párrafo del artículo 9 del D.S. Nº 014-92-EM que reconoce a la concesión minera como un bien inmueble, específicamente señala que "es un inmueble distinto y separado del predio donde se encuentre ubicada".

De igual manera, el artículo 885 del D.L. No 295 determina los bienes que son considerados inmuebles, en el inciso 3 señala a "las minas, canteras y depósitos de hidrocarburos", y en el inciso 8 a las "concesiones mineras obtenidas por particulares".

El artículo 9 del D.S. No 014-92-EM, hace referencia a las partes accesorias e integrantes de la concesión, determina que las primeras son aquellos bienes "propiedad del concesionario que estén aplicados de modo permanente al fin económico de la concesión".

En base a la noción de bienes accesorios, el artículo 888 señala lo siguiente:

Son accesorios los bienes que, sin perder su individualidad, están permanentemente afectados a un fin económico u ornamental con respecto a otro bien. La afectación sólo puede realizarla el propietario del bien principal o quien tenga derecho a disponer de él, respetándose los derechos adquiridos por terceros (Decreto Legislativo No 295, 1984).

Sobre las partes integrantes, el artículo 887 del Código Civil señala que son las partes que no pueden ser separadas sin "destruir, deteriorar o alterar el bien". De manera más específica, son: "Las labores ejecutadas tendentes al aprovechamiento de tales sustancias" como señala la parte final del artículo 9 del (Decreto Supremo No 014-92EM, 1992).

El TUO de la LGM reconoce cinco tipos de concesiones mineras: "las actividades de exploración, explotación, beneficio, labor general y transporte minero son ejecutadas por personas naturales y jurídicas nacionales o extranjeras, a través del sistema de concesiones" como afirma en el artículo 7. 
Las definiciones y los artículos que regulan dichas concesiones mineras se pueden encontrar en el Capítulo I dentro del subcapítulo "Las Actividades Mineras".

El Instituto Geológico, Minero y Metalúrgico cuenta con la autoridad para el otorgamiento de la concesión de exploración y explotación, y desde el año 2007, los Gobiernos Regionales la poseen sobre la pequeña minería y la minería artesanal (Baldeón Ríos, 2016, pág. 261). El Diario Oficial "El Peruano" publica una vez al mes la lista de las concesiones mineras que fueron otorgadas a los particulares durante el transcurso del mes anterior a la publicación.

Para la concesión de beneficio, el solicitante debe presentar una solicitud a través del formulario electrónico del portal web del MINEM, a la DGM o Gobierno Regional como señala el artículo 35 del D.S. N ${ }^{\circ}$ 018-92-EM, además de incluir también todos los requisitos que menciona el artículo.

La entidad competente para solicitar una concesión de labor general es la DGM, dentro de los diez días hábiles posteriores notifica a los concesionarios mineros solicitantes para que realicen una Junta de Concesionarios, consentida la ejecución de la obra, la entidad competente otorga el título de la concesión y transcribe la resolución al Registro Público de Minería, según el artículo 41 del (Decreto Supremo Nº 018-92-EM, 1992).

Sobre la concesión de transporte minero, el interesado deberá presentar una solicitud con todos los requisitos del artículo 42 ante la DGA, quién de haberse acreditado los requisitos: "Emitirá la resolución que aprueba el proyecto de la concesión de transporte minero, autoriza la construcción del sistema de transporte, otorga la concesión de transporte y autoriza su funcionamiento" (Decreto Supremo No 018-92-EM, 1992).

\subsection{Escalas de producción en la minería}

El artículo III del Título Preliminar del TUO de la LGM regula que "el Estado protege y promueve la pequeña minería y la minería artesanal, así como la mediana minería, y promueve la gran minería”. 
Empezando por la pequeña minería, esta se caracteriza porque su explotación se desarrolla de manera subterránea, con empleo de mano de obra y carencia de una infraestructura desarrollada; suelen localizarse en zonas andinas alejadas de los centros de fundiciones y puertos (Baldeón Ríos, 2016, pág. 130).

El TUO de la LGM no define a la pequeña minería pero señala que los sujetos que participan en dicha industria minera son los pequeños productores mineros, en el artículo 91 regula quienes deben ser considerados como tales:

Son pequeños productores mineros los que:

1. En forma personal o como conjunto de personas naturales, o personas jurídicas conformadas por personas naturales o cooperativas mineras o centrales de cooperativas mineras se dedican habitualmente a la explotación y/o beneficio directo de minerales; $y$

2. Posean, por cualquier título, hasta dos mil $(2,000)$ hectáreas, entre denuncios, petitorios y concesiones mineras; $\mathrm{y}$, además.

3. Posean, por cualquier título, una capacidad instalada de producción y/o beneficio no mayor de trescientas cincuenta (350) toneladas métricas por día. En el caso de los productores de minerales no metálicos y materiales de construcción, el límite máximo de la capacidad instalada de producción y/ o beneficio será de hasta un mil doscientas $(1,200)$ toneladas métricas por día.

En el caso de los yacimientos metálicos tipo placer, el límite máximo de la capacidad instalada de producción y/o beneficio, será de tres mil $(3,000)$ metros cúbicos por día (Decreto Supremo No 014-92-EM).

En segundo lugar, el concepto de minería artesanal fue introducido en la Legislación Peruana de la siguiente manera:

"La minería artesanal es una actividad de subsistencia que se sustenta en la utilización intensiva de mano de obra que la convierte en una gran fuente de generación de empleo y de beneficios colaterales productivos en las áreas de influencia de sus operaciones, que generalmente son las más apartadas y deprimidas del país, constituyéndose en polos de desarrollo” (Ley No 27651, 2002). 
El minero artesanal es aquel que se dedica personalmente o como grupo de persona naturales o personas jurídicas, de manera habitual y como conducto de sustento, a la explotación de minerales, y que realiza sus actividades mediante procedimientos manuales o con el uso de equipos básicos (Torres, 2007, pág. 67).

La minería artesanal en las últimas décadas ha obtenido una mayor relevancia social y económica, debido a que en la mayoría de las zonas donde se desarrolla sus habitantes viven en ausencia de condiciones básicas de salud, educación y vivienda; y esta actividad les da la oportunidad de mejorar individualmente y como comunidad.

La segunda parte de artículo 91 del TUO de la LGM, indica quienes son los Productores Mineros Artesanales:

Son productores mineros artesanales los que:

1. En forma personal o como conjunto de personas naturales o personas jurídicas conformadas por personas naturales, o cooperativas mineras o centrales de cooperativas mineras se dedican habitualmente y como medio de sustento, a la explotación y/o beneficio directo de minerales, realizando sus actividades con métodos manuales y/o equipos básicos; $\mathrm{y}$

2. Posean, por cualquier título, hasta un mil $(1,000)$ hectáreas, entre denuncios, petitorios y concesiones mineras; o hayan suscrito acuerdos o contratos con los titulares mineros según lo establezca el reglamento de la presente ley; y, además; 3. Posean, por cualquier título, una capacidad instalada de producción y/o beneficio no mayor de veinticinco (25) toneladas métricas por día. En el caso de los productores de minerales no metálicos y de materiales de construcción, el límite máximo de la capacidad instalada de producción y/o beneficio será de hasta cien (100) toneladas métricas por día. En el caso de los yacimientos metálicos tipo placer, el límite máximo de capacidad instalada de producción y/o beneficio será de doscientos (200) metros cúbicos por día (Decreto Supremo Nº14-92-EM).

En tercer lugar, la mediana minería se encuentra dentro del llamado "régimen general" junto con la gran minería, los titulares de ambos deben tener más de 2,000 hectáreas en concesiones y contar con una suficiencia de producción mayor a 350 toneladas métricas por día. 
Samamé Boggio indica lo siguiente sobre la mediana minería:

Es la escala intermedia entre la pequeña y gran minería. Constituye el grado de optimización y avance de la pequeña minería. Se caracteriza porque la explotación minera es subterránea con vetas más amplias, relativa mecanización, operación casi integrada, se cuenta a veces con plantas de beneficio, déficit relativo a la energía, transporte y comunicaciones y los centros de producción están también alejados de los puertos y fundiciones, como se citó en (Baldeón Ríos, 2016, pág. 134).

Por último, la gran minería es la máxima optimalización de la industria minera, requiere de una mayor inversión de dinero, posee más hectáreas otorgadas en concesión, mayor número de trabajadores y una mayor capacidad productiva.

(Torres, 2007) indica lo siguiente sobre la minería a gran escala:

El proceso productivo en la minería a gran escala se compone en lo fundamental en cinco etapas: exploración, desarrollo y preparación, producción o explotación, concentración y; fundición y refinación. Su proceso productivo se encuentra altamente mecanizado, logrando explotar de esa manera grandes yacimientos (pág. 18).

Los aportes de la gran minería en la vida económica y social de cualquier país se efectiviza de diversas maneras: compras en el mercado nacional, creación de puestos de trabajo, atracción del capital extranjero, generación de recursos fiscales y contribución al desarrollo social (Torres, 2007, pág. 50).

En cuando a las entidades competentes para recibir los petitorios de concesión minera, el artículo 12 del Reglamento de Procedimientos Mineros regula lo siguiente:

Los administrados que cuenten con constancia vigente de Pequeños Productores Mineros y Productores Mineros Artesanales, deben presentar sus petitorios de concesión minera ante el Gobierno Regional competente. 
Los administrados sujetos al régimen general, deben presentar sus petitorios de concesión minera ante cualquiera de las mesas de partes del Instituto Geológico, Minero y Metalúrgico - INGEMMET (Decreto Supremo No 018-92-EM, 1992).

\subsection{Derechos de los concesionarios mineros}

Desde el momento que el estado peruano le otorga a un particular una concesión minera, luego de acreditar todos los requisitos que la ley exige, este adquiere derechos y también obligaciones. Empezando por los derechos, el Título Quinto del TUO de la LGM regula los derechos comunes que poseen los titulares de las concesiones mineras, el artículo 37 regula lo siguiente:

Los titulares gozan de estos atributos:

1. En las concesiones que se otorguen en terrenos eriazos, al uso minero gratuito de la superficie correspondiente a la concesión, para el fin económico de la misma.

2. A solicitar a la autoridad minera el derecho de uso minero gratuito para el mismo fin, sobre terrenos eriazos ubicados fuera de la concesión.

3. A solicitar autorización para establecer servidumbres en terrenos de terceros que sean necesarios para la racional utilización de la concesión, previa indemnización justipreciada si fuere el caso.

4. A solicitar autorización para establecer uso minero o servidumbres sobre los terrenos superficiales de otras concesiones.

5. A construir en las concesiones vecinas, las labores que sean necesarias al acceso, ventilación y desagüe de su propias concesiones, transporte de los minerales y seguridad de los trabajadores.

6. A ejecutar en terreno franco las labores que tengan los mismos objetos señalados en el inciso anterior.

7. A solicitar la expropiación, previa indemnización justipreciada, de los inmuebles destinados a otro fin económico, si el área fuera necesaria para la racional utilización de la concesión y se acreditase la mayor importancia de la industria minera sobre la actividad afectada.

8. A usar las aguas que sean necesarias para el servicio doméstico del personal de trabajadores y para las operaciones de la concesión, de conformidad con las disposiciones legales sobre la materia.

9. A aprovechar las sustancias minerales contenidas en las aguas que alumbren con sus labores. 
10. A inspeccionar las labores de concesiones mineras vecinas o colindantes, cuando sospeche internación o cuando tema inundación, derrumbe o incendio, por el mal estado de las labores de los vecinos o colindantes, por el desarrollo de los trabajos que se efectúen en éstos.

11. A contratar la ejecución de los trabajos de exploración, desarrollo, explotación y beneficio, con empresas especializadas inscritas en la Dirección General de Minería (Decreto Supremo No 014-92-EM, 1992).

\subsection{Obligaciones de los concesionarios mineros}

Además de los derechos antes mencionados, los titulares de las concesiones mineras deben obedecer ciertos mandatos que emanan de las leyes especiales, en orden de mantener vigente dichas concesiones mineras. El cumplimiento de estas obligaciones son de carácter obligatorio, tanto por parte del Estado como por parte de los privados.

Como señala (Belaunde Moreyra, 2011) de manera general se pueden clasificar las obligaciones de la siguiente manera:

Las obligaciones legales del concesionario frente a la autoridad minera por el ejercicio de la industria, pueden ser clasificados en dos grandes categorías: a) aquellas vinculadas con la vigencia de la concesión, cuyo incumplimiento determina que se produzca una causal de extinción; y b) aquellas otras obligaciones legales que no están vinculadas directamente con la vigencia de la concesión, pero cuyo incumplimiento puede generar sanciones de otra índole, tales como multas, restitución de lo indebidamente extraído, indemnización por daños y perjuicios; suspensión de labores mineras en los casos de daño o peligro para otros concesionarios o terceros (pág. 103).

Algunas de las obligaciones que se mencionarán a continuación consisten en el abono del derecho de vigencia, la producción mínima, y en el caso en que estos no se puedan completar, el pago de penalidades. A su vez, algunas obligaciones se aplican a un determinado tipo de concesión, así como existen otras de carácter más general.

Empezando, "El derecho de vigencia es una retribución económica que realiza el solicitante al Estado por el derecho de otorgamiento de la concesión minera, distinto al 
derecho de tramitación", luego de que la solicitud es aprobada, el pago se realiza a favor del estado por "el derecho al aprovechamiento de los recursos naturales" (Baldeón Ríos, 2016, pág. 307).

El TUO de la LGM regula en el artículo 39:

"A partir del año en que se hubiere formulado el petitorio, el concesionario minero estará obligado al pago del Derecho de Vigencia. El Derecho de Vigencia es de US\$ 3,00 o su equivalente en moneda nacional por año y por hectárea solicitada u otorgada.

Para los pequeños productores mineros, el Derecho de Vigencia es de US\$ $1.00 \mathrm{o}$ su equivalente en moneda nacional por año y por hectárea solicitada u otorgada. Para los productores mineros artesanales el Derecho de Vigencia es de US\$ 0.50 o su equivalente en moneda nacional por año y por hectárea solicitada u otorgada. El Derecho de Vigencia correspondiente al año en que se formule el petitorio de la concesión minera, deberá abonarse y acreditarse con motivo de la formulación del petitorio. El Derecho de Vigencia correspondiente al segundo año, computado a partir del 1 de enero del año siguiente a aquel en que se hubiere formulado el petitorio de la concesión minera, deberá abonarse hasta el 30 de junio del segundo año. Igual regla se aplicará para los años siguientes”.

(Decreto Supremo No 014-92-EM, 1992).

No realizar el pago del derecho de vigencia o la penalidad oportunamente durante dos años consecutivos o no consecutivos ocasiona la caducidad; si no se realiza el abono de un año se puede regularizar con el pago y acreditación del año corriente y se imputa al año anterior que se venció y no se pagó, como señala el artículo 59 del (Decreto Supremo No 014-92-EM, 1992).

Pasando a la siguiente obligación, el artículo 38 del TUO de la Ley General de Minería regula la inversión y producción mínima exigida por ley:

La producción no podrá ser inferior al equivalente a una UIT por año y por hectárea otorgada, tratándose de sustancias metálicas y del equivalente al 10\% de la UIT por año y por hectárea otorgada, tratándose de sustancias no metálicas. En el caso de pequeños productores mineros la producción no podrá ser inferior al 
equivalente a $10 \%$ de la UIT por año y por hectárea otorgada en caso de sustancias metálicas y de 5\% de la UIT por año y por hectárea en el caso de la minería no metálica. Para el caso de productores mineros artesanales la producción no podrá ser inferior al 5\% de la UIT por año y por hectárea otorgada sea cual fuere la sustancia. La producción deberá obtenerse no más tarde del vencimiento del décimo año, computado a partir del año siguiente en que se hubiera otorgado el título de concesión. La producción deberá acreditarse con liquidación de venta.

Es importante hacer hincapié en que la concesión minera obliga a que se trabaje sobre ella, esto en razón que los minerales se consideran Patrimonio de la Nación y se deben generar beneficios económicos con su explotación. Esto se vería afectado si se permitiera la inactividad, ya que la concesión minera podría haber sido otorgada a otro particular que si estuviera en condiciones de cumplir con las obligaciones.

No en todos los casos los concesionarios mineros cumplen de manera oportuna o correcta con la obligación que exige la inversión o producción mínima. "El pago de penalidad por falta de producción o inversión mínima, es una obligación alternativa para mantener amparado el derecho minero" (Pothier R. , 1978).

La penalidad equivale al pago del "10\% de la producción mínima anual exigible por año y por hectárea", "hasta que cumpla con la producción o inversión mínima anual”, como señala el artículo 40 del (Decreto Supremo No 014-92-EM, 1992). Se debe realizar desde el undécimo año, aunque la caducidad solo se declarará en caso el concesionario minero continúe sin cumplir con la obligación de inversión y producción mínima hasta el termino del décimo quinto año.

Esa es la regla general, pero el artículo 41 determina la siguiente excepción: no se declarará la caducidad si dicho incumplimiento "se debe a caso fortuito o fuerza mayor o por algún hecho no imputable al titular de actividad minera debidamente sustentado y aprobado por la autoridad competente". A su vez, se le otorgará un "plazo máximo de cinco años no prorrogables" para regularizar sus actividades (Decreto Supremo No 01492-EM, 1992). 
(Belaunde Moreyra, 2011) expone un ejemplo que ayuda a la compresión del artículo antes mencionado:

Un titular de 10 concesiones mineras en lugar de trabajarlas simultáneamente, podrá trabajar una o varias de ellas, siempre que se alcance el valor de la producción/venta mínima por el total de las diez. Se cumplirá con la obligación e inversión mínima correspondiente a las diez concesiones, sin que necesariamente en todas se haya efectuado la inversión mínima, o todas estén siendo trabajadas con la producción mínima señalada por ley (pág. 114).

Otra obligación de suma importancia como indica el artículo 48 es que los titulares lleven a cabo sus labores: "De acuerdo con sistemas, métodos y técnicas que tiendan al mejor desarrollo de la actividad y con sujeción a las normas de seguridad e higiene y saneamiento ambiental aplicables a la industria minera" (Decreto Supremo No 014-92EM, 1992).

Asimismo, se regulan las siguientes obligaciones: a facilitar la entrada a las autoridades mineras para que fiscalicen; a admitir a los universitarios de las carreras de Ingeniería de Minas, Metalúrgica, Geológica, Industrial y Química en trabajos; cubiertas dichas especialidades, con alumnos de otras carreras; y a entregar de manera anual una DAC.

El artículo 52 determina que: "La persona que extraiga sustancias minerales sin derecho alguno, devolverá al Estado los minerales indebidamente extraídos, o sus valores, sin deducir costo alguno y sin perjuicio de la acción judicial a que hubiere lugar" (Decreto Supremo No 014-92-EM, 1992).

En caso de un procedimiento administrativo de extracción ilícita de sustancias minerales sin derecho alguno, la Dirección General de Minería iniciará las investigaciones, cubicación y valorización del mineral extraído, y dispondrá la sanción que corresponda: devolución de los minerales sin deducir costos o pago de su valor comercial y la inmediata paralización de la actividad ilícita (Baldeón Ríos, 2016, pág. 328). 


\section{CAPÍTULO III: LICENCIAS, PERMISOS Y AUTORIZACIONES PARA EL INICIO DE ACTIVIDADES DE EXPLORACIÓN Y EXPLOTACIÓN}

El título habilitante, la concesión minera, no es lo único que necesitan los titulares de las concesiones mineras para realizar actividad minera, la cual es una actividad compleja que abarca ámbitos mineros, ambientales, sociales, civiles, así como el uso de otros recursos naturales. Debido a ello, en el presente capítulo se desarrollará cuales son las autorizaciones, licencias y permisos que se necesitan según la vigente legislación para poder realizar actividad minera de manera legal, la manera en qué se tramitan y ante qué entidades del Estado.

El artículo 23 regula los requisitos que debe acreditar el titular de la concesión minera para poder ejecutar actividades mineras de exploración y explotación, son los siguientes:

“a) Gestionar la aprobación del Instituto Nacional de Cultura de las declaraciones, autorizaciones o certificados que son necesarios.

b) Contar con la certificación ambiental emitida por la autoridad ambiental competente.

c) Obtener el permiso para la utilización de tierras mediante acuerdo previo con

el propietario del terreno superficial o la culminación del procedimiento de servidumbre administrativa.

d) Obtener las demás licencias, permisos y autorizaciones que son requeridos en la legislación vigente, de acuerdo con la naturaleza y localización de las actividades que va a desarrollar.

Esta precisión deberá constar en el título de la concesión minera”.

(Decreto Supremo No 018-92-EM, 1992) 
Asimismo, el artículo 23 del D.S. N 018-92-EM indica que el "título de la concesión minera deberá contener la misma información exigida por el numeral 1) del artículo 17 del presente Reglamento".

Dicho artículo 17 del (Decreto Supremo Nº18-92-EM, 1992) señala que se debe presentar la siguiente información:

a) Los nombres, apellidos, nacionalidad, estado civil, domicilio, número del Documento Nacional de Identidad o Carné de Extranjería, Registro Único de Contribuyente-R.U.C. activo y el correo electrónico del peticionario, así como los nombres, apellidos, número del Documento Nacional de Identidad o Carné de Extranjería y nacionalidad del cónyuge, de ser el caso. Si el petitorio fuere formulado por una persona jurídica, se señalarán los datos de su inscripción en los Registros Públicos, así como los datos generales de su representante legal, incluyendo su correo electrónico.

b) Nombre del petitorio.

c) Distrito, provincia o región donde se encuentra ubicado el petitorio.

d) Clase de concesión, según se trate de sustancias metálicas o no metálicas

e) Identificación de la cuadrícula o de la poligonal cerrada del conjunto de cuadrículas solicitadas, con coordenadas UTM.

f) Extensión superficial del área solicitada, expresada en hectáreas;

g) Identificación de la cuadrícula o conjunto de cuadrículas colindantes.

h) Nombres, apellidos y domicilio del propietario del terreno superficial donde se ubique la concesión minera solicitada.

i) Compromiso Previo en forma de Declaración Jurada del peticionario ${ }^{1}$.

\subsection{Autorización para el inicio/reinicio de las actividades de exploración y explotación}

El artículo 75 del Reglamento de Procedimientos Mineros determina como obtener la autorización que permita al concesionario minero realizar actividad minera de exploración:

\footnotetext{
${ }^{1}$ Inciso incluído por el artículo 1 del D.S. N 042-2003-EM, el compromiso previo incluye un enfoque de desarrollo sostenible responsable, respetando los acuerdos sociales, el fomento del empleo local, la contribución al desarrollo económico local o regional y el respeto por la cultura local.
} 
75.1 El solicitante de una autorización de actividades de exploración debe presentar una solicitud a través del formulario electrónico vía extranet del portal web del Ministerio de Energía y Minas, a la Dirección General de Minería o Gobierno Regional con los requisitos exigidos en los incisos a) y c) del numeral 1) del Artículo 17 del presente Reglamento .

75.2 La autorización de actividades de exploración es de aprobación automática o de evaluación previa, según corresponda.

75.3 Autorización de actividades de exploración de aprobación automática:

a) Nombre y código de concesión(es) minera(s).

b) Número de la Resolución que aprueba el instrumento de gestión ambiental.

c) Programa de trabajo y programa de seguridad.

d) CIRA o PMA.

e) Declaración Jurada del titular de actividad minera donde se indique que es propietario del predio o que está autorizado por el (los) propietarios del 100\% de las acciones y derechos del predio donde se realizará la actividad de exploración. f) Documento emitido por la Dirección General de Minería o el Ministerio de Cultura, que acredite que el ámbito geográfico de la actividad de exploración no se encuentra dentro de los alcances de la Ley $N^{\circ} 29785$.

La Dirección General de Minería emite una constancia de aprobación automática en el plazo máximo de cinco días hábiles.

75.4 La autorización de las actividades de exploración está sujeta a un procedimiento de evaluación previa, en caso se compruebe que el ámbito geográfico de la actividad de exploración a ejecutarse se encuentra dentro de los alcances de la Ley $N^{\circ} 29785$ y su reglamento aprobado con Decreto Supremo No 001-2012-MC.

El titular de la actividad minera presenta conjuntamente con su solicitud los requisitos señalados en los incisos a), b), c) y e) del numeral 75.3 del presente artículo.

La Dirección General de Minería o Gobierno Regional correspondiente autoriza el inicio de la actividad de exploración, previa presentación del CIRA o PMA. El plazo del procedimiento de evaluación previa no es mayor de quince días hábiles y se sujeta al silencio negativo (Decreto Supremo No 018-92-EM, 1992). 
Como se observa en el anterior artículo la autorización de actividades de exploración puede ser de aprobación automática o de evaluación previa, según sea el caso. Nos encontramos en el segundo escenario cuando la actividad de exploración va a ejecutarse en un territorio dentro del alcance de la Ley $\mathrm{N}^{\circ} 29785$, que reconoce el convenio 169 de la Organización Internacional del Trabajo (OIT), y su reglamento, el D.S. No 001-2012-MC.

Sobre la autorización de las actividades de explotación, el procedimiento para conseguirlo se regula en el artículo 76, cuyo texto es el siguiente:

76.1 El solicitante de una autorización de actividades de explotación (incluye aprobación del plan de minado y botaderos) que no se encuentre en el supuesto regulado en el numeral 76.6 del presente reglamento, debe presentar una solicitud a través del formulario electrónico vía extranet del portal web del Ministerio de Energía y Minas, a la Dirección General de Minería o Gobierno Regional con los mismos requisitos exigidos en los incisos a) y c) del numeral 1) del Artículo 17 del presente Reglamento. Asimismo, debe acompañar los siguientes documentos:

a) Nombre y código de concesión minera o UEA.

b) Número de la Resolución que aprueba el instrumento de gestión ambiental

c) Información técnica de acuerdo a los parámetros establecidos en el Anexo I.

d) Documento que acredite que el solicitante es propietario o que está autorizado por el(los) propietario(s) del 100\% de las acciones y derechos del predio.

e) Copia del CIRA o PMA.

f) Autorización de la autoridad competente, en caso de que el proyecto a ejecutarse afecte carreteras u otro derecho de vía. En caso de no afectación el titular de la actividad minera debe presentar una declaración jurada.

76.2 El titular de actividad minera debe solicitar la modificación de la autorización de explotación, ante la Dirección General de Minería o Gobierno Regional.

(i) Para cambio del método de explotación superficial a subterráneo o viceversa.

(ii) Ampliación del límite final de la explotación del tajo o nuevas bocaminas, siempre y cuando se requiera la acreditación de uso de terreno superficial adicional a los autorizados y que no se encuentre dentro de los supuestos de ITM. 
(iii) Construcción de un nuevo depósito de desmonte o su recrecimiento que no se encuentre dentro de los supuestos de ITM.

Las modificaciones no contempladas anteriormente son aprobadas por la Gerencia General del titular de actividad minera o el órgano que haga sus veces dentro de la Unidad Minera o Unidad de Producción.

76.4 La Dirección General de Minería o Gobierno Regional autoriza las actividades de explotación o su modificación dentro de los treinta días hábiles siguientes a la fecha de presentación de la solicitud (Decreto Supremo Nº 018-92EM).

Los documentos presentados por los concesionarios mineros para la gestión de sus trámites se encuentran en condiciones de ser luego verificados por la DGM o el Gobierno Regional competente, conforme dispone el artículo 35 del (Decreto Supremo $\left.\mathrm{N}^{\circ} 018-92-\mathrm{EM}\right)$.

\subsection{Acreditación de propiedad o autorización de uso del terreno superficial}

La concesión minera es un bien inmueble distinto del predio dónde se ubica, lo que permite la implementación de mecanismos como el uso minero o habilita la transferencia de la concesión sin que haya necesidad de configurar un derecho nuevo sobre el predio (Gamarra Barrantes, 2009, pág. 59).

El Código Civil en el artículo 954 regula la extensión del derecho de propiedad, cuyo texto es el siguiente:

La propiedad del predio se extiende al subsuelo y al sobresuelo, comprendidos dentro de los planos verticales del perímetro superficial y hasta donde sea útil al propietario el ejercicio de su derecho.

La propiedad del subsuelo no comprende los recursos naturales, los yacimientos y restos arqueológicos, ni otros bienes regidos por leyes especiales.

Dicho artículo se encuentra en concordancia con el artículo 66 de la Constitución Política (1993) que señala que "los recursos naturales, renovables y no renovables, son patrimonio de la Nación” y que "el Estado es soberano en su aprovechamiento". 
Los documentos que se deben presentar para acreditar el mencionado requisito por parte del propietario o los propietarios del mismo, son los indicados en el artículo 35 del Reglamento de Procedimientos Mineros. Si bien este artículo está dirigido a los solicitantes de una concesión de beneficio, ordena y aclara el marco jurídico al cual seguir.

(Galiano Gallardo, Tesis para optar el grado de Magíster en Derecho de la Empresa con mención en Gestión Empresarial, 2016) resume el porqué la servidumbre minera ya no se aplica:

La servidumbre minera ha caído en desuso porque se debe seguir un procedimiento previo que determine la falta de acuerdo sobre el uso del terreno superficial, y si en el procedimiento de servidumbre minera se determina que se enerva el derecho de propiedad, es decir, que perjudica el resto del predio sirviente de tal modo que lo haga inútil o lo afecte de manera sustantiva respecto de los fines para los cuales estaba siendo usado o estuviese destinado, la solicitud será denegada.

\subsection{Instrumento de Gestión Ambiental}

Los IGA son los instrumentos dirigidos a la correcta aplicación de la política ambiental, en respeto de los principios que establece la Ley General del Ambiente y las demás normas jurídicas que la complementan y reglamentan, según el artículo 16 de la (Ley $\mathrm{N}^{\circ}$ 28611, 2005).

Los Instrumentos de Gestión Ambiental pueden planificar, prevenir, controlar, corregir o fiscalizar las actividades con impactos ambientales, entre otras funciones; además, se entiende que lo constituyen todos los sistemas ambientales a nivel nacional, sectorial o local, y el Estado debe velar porque se apliquen de manera complementaria, según el artículo 17 (Ley Nº 28611, 2005).

La Ley del SEIA creó el Sistema Nacional de Evaluación del Impacto Ambiental, el artículo 1 señala: 
La presente Ley tiene por finalidad:

a) La creación del Sistema Nacional de Evaluación del Impacto Ambiental (SEIA), como un sistema único y coordinado de identificación, prevención, supervisión, control y corrección anticipada de los impactos ambientales negativos derivados de las acciones humanas expresadas por medio del proyecto de inversión.

b) El establecimiento de un proceso uniforme que comprenda los requerimientos, etapas, y alcances de las evaluaciones del impacto ambiental de proyectos de inversión.

c) El establecimiento de los mecanismos que aseguren la participación ciudadana en el proceso de evaluación de impacto ambiental (Ley Nº 27446, 2001).

Antes de que la autoridad ambiental competente emita una decisión respecto de la viabilidad de un proyecto, debe evaluar los criterios y procedimientos establecidos, luego los resultados son utilizados para aprobar o no el EIA, dicho proceso adopta el nombre de Evaluación de Impacto Ambiental, como señala el 4 del (Decreto Supremo $N^{\circ}$ 040-2014-EM, 2014).

(Foy Valencia, 2013) opina lo siguiente sobre la EIA:

"Es un procedimiento jurídico-administrativo de recolección de información, análisis y predicción, destinado a anticipar, corregir y prevenir los posibles efectos directos e indirectos que la ejecución de una determinada obra o proyecto causa sobre el medio ambiente, permitiendo así que la administración adopte medidas adecuadas para su protección” (pág. 131).

En general, las etapas que comprenden los procedimientos para la obtención de una certificación ambiental son las siguientes y en este orden: presentar la solicitud, la acción es clasificada, se evalúa el instrumento presentado, se emite la resolución y se continúa con el respectivo seguimiento, así lo aclara el artículo 6 de la (Ley No 27446, 2001).

Los Instrumentos de Gestión Ambiental, según corresponda, deben incluir: el detalle de la propuesta, la identificación y características de los impactos ambientales negativos, la maniobra de manejo ambiental, la participación ciudadana, los planes de 
seguimiento, una valoración económica, además de lo que determine la autoridad que tiene la competencia, según señala el artículo 10 de la Ley del SEIA.

Tabla 3.1

Categorías de los proyectos de acuerdo al impacto ambiental

\begin{tabular}{|c|c|}
\hline $\begin{array}{l}\text { Categoría I } \\
\text { Declaración de Impacto Ambiental } \\
\text { (DIA) }\end{array}$ & $\begin{array}{l}\text { Incluye los proyectos cuya ejecución no origina } \\
\text { impactos ambientales negativos significativos. }\end{array}$ \\
\hline $\begin{array}{l}\text { Categoría II } \\
\text { Estudio de Impacto Ambiental Semidetallado } \\
\text { (EIA-sd) }\end{array}$ & $\begin{array}{l}\text { Abarca los proyectos cuya realización puede } \\
\text { generar impactos ambientales moderados y cuyos } \\
\text { efectos negativos pueden ser suprimidos o } \\
\text { minimizados mediante la toma de medidas fáciles } \\
\text { de aplicar. }\end{array}$ \\
\hline $\begin{array}{l}\text { Categoría III } \\
\text { Estudio de Impacto Ambiental Detallado } \\
\text { (EIA-d ) }\end{array}$ & $\begin{array}{l}\text { Abarca los proyectos cuyas características y } \\
\text { localización, pueden generar impactos ambientales } \\
\text { negativos significativos, cuantitativa o } \\
\text { cualitativamente, requiriendo un análisis profundo } \\
\text { para revisar sus impactos y proponer la estrategia } \\
\text { de manejo ambiental correspondiente. }\end{array}$ \\
\hline
\end{tabular}

Fuente: Artículo 4 de la Ley N² 27446. Elaboración Propia.

A través del (Decreto Supremo No 040-2014-EM), se aprobó el Reglamento de protección y gestión ambiental para las actividades mineras aplicables a la mediana y a la gran minería. El artículo 3 menciona que dicho reglamento se aplica supletoriamente a las demás actividades mineras; sin embargo, no se pueden incluir las actividades de la pequeña minería y la minería artesanal debido a que cuentan con sus propias leyes, las cuales se van a desarrollar más adelante.

Los proyectos mineros que contengan actividades de explotación y/o beneficio deberán ser incluidos en la Categoría III $^{2}$. Las actividades de labor general, transporte o almacenamiento de minerales, podrán ser clasificados en la Categoría II o III, siempre dentro del marco de la Ley del SEIA, como señala el artículo 25 (Decreto Supremo No 040-2014-EM, 2014).

\footnotetext{
${ }^{2}$ El artículo 38 del D.S Nº 019-2009-MINAM, señala que los proyectos que impliquen desplazamientos o reubicación de personas, deberán ser incluidos de manera obligatoria en la Categoría III.
} 
Con la Ley N 29968 se creó el SENACE, el cual es el Servicio Nacional de Certificación Ambiental para las Inversiones Sostenibles, una institución adscrita al Ministerio del Ambiente.

El SENACE es la entidad del Estado competente para evaluar y aprobar los EIA detallados (Categoría III) regulados en la Ley del SEIA es decir, sobre los proyectos que producen impactos negativos significativos en el medio ambiente.

Hasta el momento el SENACE viene completando la transferencia de funciones de los sectores de minería, energía, transporte y agricultura, siendo este último el más actual; además, piensa completar la agenda de transferencia de funciones de los sectores al SENACE establecido en el Decreto Supremo N 006-2015-MINAM, el cual incluye los sectores vivienda y construcción, pesca, salud, comunicaciones, entre otros. La idea es que en un futuro dicha institución se encargue de evaluar y aprobar todos los EIA detallados, abarcar de esa manera todos los sectores y unificando requisitos $\mathrm{y}$ procedimientos bajo la supervisión de profesionales especializados.

Respecto a los EIA semidetallados (EIA-sd), que se encuentran dentro de la clasificación de la Categoría II, la autoridad competente es el sector correspondiente de acuerdo al proyecto a realizarse. Se Incluyen los proyectos que son capaces de generar impactos ambientales no positivos en un nivel moderado.

Pueden ser clasificados como categoría II las actividades de labor general, transporte o almacenamiento; la explotación de los pequeños productores y los productores artesanales; y los proyectos de exploración minera de la mediana o gran minería. En todos los casos, dependerá de que se encuentren dentro de los límites de dicha categoría, caso contrario, deberán subir o bajar una.

Para la elaboración o modificación de un EIA detallado como semidetallado se deben cumplir con las siguientes obligaciones: levantamiento de información de campo, la línea base, el reconocimiento y análisis de los efectos, y la elaboración del plan de participación ciudadana, según se resume la información del artículo 29 (Decreto Supremo No 040-2014-EM, 2014). 
Sobre la Declaración de Impacto Ambiental (Categoría I), la cual incluye los proyectos que no generan impactos negativos en el medio ambiente de carácter significativo, se encuentran sujetos a presentarlo para el inicio de las actividades de los pequeños productores y los mineros artesanales, de acuerdo al caso, para que puedan obtener la certificación ambiental a la que hace referencia la Ley del SEIA, según indica el artículo 15 (Ley Nº 27651, 2002).

El (Decreto Supremo No 040-2014-EM, 2014) en el artículo 10 señala lo siguiente:

Los Gobiernos Regionales, a través de sus órganos establecidos, son competentes para conducir el proceso de categorización, revisión y aprobación de los estudios ambientales, en el marco del Sistema Nacional de Evaluación de Impacto Ambiental. Asimismo, fiscalizan y sancionan las actividades de minería informal e ilegal en el marco de sus competencias y conducen el proceso de formalización minera.

Además, las actividades de exploración minera de la gran o mediana minería que no generen impactos ambientales negativos significativos pueden ser catalogados en la Categoría I o II.

La autoridad encargada de la evaluación y aprobación de los Instrumentos de Gestión Ambiental para la exploración minera es la DGAAM; la OEFA se encomienda a la fiscalización y sanción ambiental; y el SENACE es la entidad facultada para clasificar los proyectos de exploración minera, como indica el artículo 4 del D.S. No 042 - 2017EM.

La presente norma jurídica introdujo la Ficha Técnica Ambiental (FTA), que es: "El Instrumento de Gestión Ambiental complementario al SEIA para los proyectos de exploración minera que por su ubicación y/o características se prevé la generación de impactos ambientales negativos no significativos", según indica el artículo 41 del D.S. No 042-2017-EM. 
Tabla 3.2

Instrumentos de Gestión Ambiental en el régimen general

\begin{tabular}{c|c|c|c|c|c}
\hline Actividad Minera & Exploración & Explotación & Beneficio & Transporte & Labor General \\
\hline $\begin{array}{c}\text { Instrumento de } \\
\text { Gestión } \\
\text { Ambiental }\end{array}$ & $\begin{array}{c}\text { FTA, DIA o } \\
\text { EIA-sd }\end{array}$ & EIA-d & EIA-d & EIA-sd o EIA-d & $\begin{array}{c}\text { EIA-sd o EIA- } \\
\mathrm{d} \mathrm{d}\end{array}$ \\
\hline $\begin{array}{c}\text { Autoridad } \\
\text { Competente }\end{array}$ & DGAAM & SENACE & SENACE & $\begin{array}{c}\text { Sector o } \\
\text { SENACE }\end{array}$ & $\begin{array}{c}\text { Sector o } \\
\text { SENACE }\end{array}$ \\
\hline
\end{tabular}

Fuente: Decreto Supremo Nº 042-2017-EM, Ley No 27446. Elaboración propia.

\subsection{Derecho de uso de agua}

El agua es un componente esencial para los ecosistemas y la vida humana, fue considerada como un medio de vida para las especies animales y vegetales; sin embargo, su uso se ha incorporado a actividades cada vez más exigentes, como la minería, con los consiguientes abusos y excesos (Andía Chávez, 2010, págs. 17-18).

"El agua es un recurso natural renovable, indispensable para la vida, vulnerable y estratégico para el desarrollo sostenible, el mantenimiento de los sistemas y ciclos naturales que la sustentan, y la seguridad de la Nación”, de acuerdo al artículo 1 (Ley No 29338, 2009).

El agua es un recurso natural que constituye un patrimonio de la Nación, por ende, su uso y administración debe beneficiar a todos los peruanos en afinidad con el bien común y con el debido cuidado por el medio ambiente. No existe propiedad privada sobre este recurso.

El artículo 35 determina el orden de prelación que se señala a continuación:

"La Ley reconoce las siguientes clases de uso de agua:

1. Uso primario.

2. Uso poblacional.

3. Uso productivo. 
La prioridad para el otorgamiento y el ejercicio de los usos anteriormente señalados sigue el orden en que han sido enunciados" (Ley No 29338, 2009).

Como señala la Ley de Recursos Hídricos, el uso primario del agua reside en el empleo directo de la fuente natural, con la finalidad de cumplir con las necesidades primarias como el consumo, la elaboración de alimentos, el aseo personal y para ceremonias culturales o religiosas (artículo 36); por otro lado, el uso poblacional “consiste en la captación del agua de una fuente o red pública, debidamente tratada, con el fin de satisfacer las necesidades humanas básicas" (artículo 39); y el uso productivo que "consiste en la utilización de la misma en procesos de producción o previos a los mismos" (artículo 42), tanto el uso poblacional como el productivo son derechos emitidos por la Autoridad Nacional ${ }^{3}$ a través de una resolución administrativa (Ley No 29338, 2009).

El artículo 43 de la Ley de Recursos Hídricos reconoce en su inciso 6) a la minería como un tipo de uso productivo del agua, siendo algunos otros el uso agrario, pesquero, industrial, medicinal o energético. La actividad minera no se puede desarrollar sin el uso del agua, razón por la cual se debe priorizar un uso racional y sostenible, evitando de esa manera generar un daño irreversible.

Existen distintas clases de derechos de uso de agua: la licencia, el permiso y la autorización. El Estado peruano posee el cargo de garantizar el correcto cumplimiento de estos derechos de uso que son concedidos a los particulares.

\subsection{Certificación de Inexistencia de Restos Arqueológicos}

El artículo II de la Ley General del Patrimonio Cultural de la Nación señala lo que debemos entender por Patrimonio Cultural:

Toda manifestación del ser humano - material o no - que por su relevancia y valor paleontológico, arqueológico, arquitectónico, histórico, artístico, militar, social, antropológico, tradicional, religioso, etnológico, científico, tecnológico o

${ }^{3}$ La Ley No 29338, señala en el artículo 4 que la Autoridad Nacional se entiende como Autoridad Nacional del Agua (ANA)". 
intelectual, sea expresamente declarado como tal o sobre el que exista la presunción legal de serlo. Dichos bienes tienen la condición de propiedad pública o privada con las limitaciones que establece la presente Ley (Ley No 28296, 2004).

Los restos arqueológicos parte del patrimonio cultural de la nación, por ende, las normas jurídicas buscan su protección y conservación; toda actividad que para su desarrollo necesita previamente la remoción del terreno superficial se encuentra obligada a contar con un CIRA.

El CIRA lo emite el Ministerio de Cultura, y mediante él se corrobora que en la zona dónde se va desenvolver el proyecto minero no se ubican restos arqueológicos (Galiano Gallardo, 2016).

El Reglamento de Intervenciones Arqueológicas en su artículo 55 determina los requisitos para solicitar satisfactoriamente el CIRA:

a) Formulario de solicitud dirigida a la Dirección de Certificaciones o a la Dirección Desconcentrada de Cultura, según el ámbito de sus competencias.

b) Presentación del expediente técnico del área materia de solicitud, en dos (2) ejemplares, conformado por:

i) Plano de ubicación del proyecto de inversión.

ii) Plano del ámbito de intervención del proyecto.

iii) Memoria descriptiva del terreno (área a certificar) con el respectivo cuadro de datos técnicos (Decreto Supremo No 003-2014-MC, 2014).

Sobre el procedimiento que se debe seguir para la obtención del CIRA se puede señalar lo siguiente:

- Si el expediente fuera observado se le otorgará al administrado un plazo no mayor a diez días hábiles para la subsanación correspondiente.

- Sin la subsanación, el expediente deberá ser declarado en abandono.

- La Dirección de Certificaciones o la Dirección Desconcentrada de Cultura emitirá el CIRA en un plazo máximo de veinte días hábiles.

(Decreto Supremo No 003-2014-MC, 2014). 
Luego de emitirse el CIRA, el titular del proyecto debe ejecutar el Plan de Monitoreo Arqueológico, el cual es necesario para prevenir y disminuir los impactos no positivos que genera la ejecución de un proyecto a los bienes que son Patrimonios Culturales, como indica el artículo 59 del Decreto Supremo Nº 003-2014-MC.

Adelantándonos al proceso de formalización minera, el D.S. Nº 003-2013-MC aprobó el PROSIC, un certificado más simple de obtener que el CIRA, pero exclusivamente dirigido a los mineros informales que se encuentran dentro del REINFO.

Los requisitos para la obtención del CIRA según el PROSIC, que se utilizan en los procesos de formalización minera, son distintos a los señalados por el Reglamento de Intervenciones Arqueológicas.

El artículo 5 del D.S. No 003-2013-MC determina los siguientes requisitos:

La solicitud dirigida al Director de Arqueología o Director Regional según corresponda, una copia simple de la resolución de aprobación del instrumento de gestión ambiental correctivo, el comprobante de pago y la presentación del expediente técnico del área materia de solicitud, conformado por una copia del plano perimétrico y un ejemplar de la memoria descriptiva del terreno firmado por un ingeniero y/o arquitecto. 


\section{CAPÍTULO IV: PROCESO DE FORMALIZACIÓN MINERA INTEGRAL}

\subsection{Productor minero artesanal y pequeño productor minero}

El artículo III del TUO de la LGM regula que "El Estado protege y promueve la pequeña minería y la minería artesanal, así como la mediana minería, y promueve la gran minería”.

La minería artesanal es una labor de subsistencia, a diferencia de la pequeña minería que se encuentra más desarrollada con capacidad de producción pero en pequeña escala. Ambas condiciones de los titulares de las concesiones mineras son las únicas permitidas para lograr la inscripción en el REINFO, los beneficios que ofrece dicho proceso no están disponibles para los concesionarios mineros del régimen general, en un claro intento del Estado de proteger a la pequeña y la minería artesanal.

Las diferencias de derechos y obligaciones que existen en las distintas escalas de producción se pueden apreciar en el siguiente cuadro:

Tabla 4.1

\begin{tabular}{|c|c|c|c|}
\hline Concepto & Minería Artesanal & Pequeña Minería & Régimen General \\
\hline $\begin{array}{l}\text { Denuncios, petitorios y } \\
\text { concesiones mineras }\end{array}$ & Hasta 1,000 hectáreas & Hasta 2,000 hectáreas & Más de 2,000 hectáreas \\
\hline $\begin{array}{l}\text { Capacidad de } \\
\text { producción }\end{array}$ & Hasta 25 TM/día & Hasta 350 TM/día & Más de 350 TM/día \\
\hline $\begin{array}{l}\text { Producción mínima } \\
\text { anual }\end{array}$ & 5\% UIT año/hectárea & $\begin{array}{c}\text { 10\% UIT año/hectárea } \\
\text { (metálico) / 5\% UIT } \\
\text { año/hectárea (no } \\
\text { metálico) }\end{array}$ & $\begin{array}{l}1 \text { UIT año/hectárea } \\
\text { (metálico) / 10\% } \\
\text { UIT/hectárea (no } \\
\text { metálico) }\end{array}$ \\
\hline Derecho de vigencia & US\$ 0.50 año/hectárea & US\$ 1,00 año/hectárea & US\$ 3,00 año/hectárea \\
\hline $\begin{array}{l}\text { Instrumentos de gestión } \\
\text { ambiental }\end{array}$ & DIA o EIA-sd & DIA o EIA-sd & DIA, EIA-sd o EIA-d \\
\hline
\end{tabular}

Fuente: los artículos 38, 39 y 91 del TUO de la Ley General de Minería y el artículo 4 de la Ley No 27446. Elaboración propia.

La parte final del artículo 91 del TUO de la LGM indica que tanto la condición de Pequeño Productor Minero como la de Productor Minero Artesanal "se acreditará ante la Dirección General de Minería mediante declaración jurada bienal”. 
El artículo 91 señala que los Productores Mineros Artesanales son aquellos que: En forma personal o como conjunto de personas naturales o personas jurídicas conformadas por personas naturales, o cooperativas mineras o centrales de cooperativas mineras se dedican habitualmente y como medio de sustento, a la explotación y/o beneficio directo de minerales, realizando sus actividades con métodos manuales y/o equipos básicos (Decreto Supremo Nº14-92-EM, 1992).

La Ley $\mathrm{N}^{\mathrm{O}} 27651$ complementa en su artículo 2 la definición de la minería artesanal agregando que "es una actividad de subsistencia" que utiliza la mano de obra como una fuente para generar empleo y que genera beneficios colaterales en las zonas donde se desarrolla, siendo estas zonas las más apartadas y deprimidas del país.

El artículo 12 del Reglamento de la ley de formalización de la pequeña minería y la minería artesanal, nos menciona los siguientes requisitos:

Para acreditar la condición de Productor Minero Artesanal, los solicitantes deberán presentar la Constancia de Pago de Derecho de Trámite y una Declaración Jurada Bienal, cuyo formulario será aprobado por la Dirección General de Minería, conteniendo lo siguiente:

a. Nombre completo de la persona natural o jurídica y su representante legal en este último caso; domicilio, teléfono.

b. Número de documento de identidad.

c. En el caso de personas jurídicas, debe consignarse los datos de inscripción en los Registros Públicos y los datos de identificación del representante legal.

d. Tratándose de personas naturales, declaración de dedicarse a la actividad minera artesanal como medio de sustento. En el caso de personas jurídicas, que son medio de sustento para los socios que la integran.

e. Provincia o provincias colindantes dentro de las que realiza sus actividades artesanales.

f. Acreditación de la titularidad de todos sus derechos mineros.

g. En el caso de acuerdo o contrato de explotación: identificación de los derechos mineros de terceros, indicando su nombre, código único, extensión y datos de inscripción. 
h. Resolución de autorización de inicio de actividades de exploración o explotación, emitida por la autoridad competente (Decreto Supremo No 0132002-EM, 2002).

Para renovar la condición de Productor Minero Artesanal, se deberá presentar la adecuada constancia de pago por el trámite y la declaración jurada bienal; una vez se verifique que se completaron todas las obligaciones legales mencionadas, se emitirá la constancia que lo acredita, como señala el artículo 15. La perdida de dicha condición se encuentra en el artículo 17 (Decreto Supremo No 013-2002-EM, 2002).

Pasando a continuación a la pequeña minería, el artículo 2 la define así:

La pequeña minería es la actividad minera ejercida a pequeña escala, dentro de los límites de extensión y capacidad instalada de producción y/o beneficio establecidos por el artículo 91 de la Ley General de Minería. La presente ley brinda a la pequeña minería un régimen promocional con el fin de fortalecer su desarrollo a nivel nacional, con el consiguiente empleo de mano de obra local y mejora de las condiciones de vida de las poblaciones aledañas (Ley $\mathrm{N}^{\mathrm{o}} 27651$, 2002).

A su vez, el artículo 91 del TUO de la Ley General de Minería señala que son pequeños productores aquellos que "en forma personal o como conjunto de personas naturales, o personas jurídicas conformadas por personas naturales o cooperativas mineras o centrales de cooperativas mineras se dedican habitualmente a la explotación y/o beneficio directo de minerales".

El artículo 5 del Reglamento de Ley $\mathrm{N}^{\circ} 27651$, determina los siguientes requisitos: Para acreditar la condición de Pequeño Productor Minero, el solicitante deberá presentar la correspondiente Constancia de Pago del Derecho de Trámite y una Declaración Jurada Bienal, cuyo formulario será aprobado por la Dirección General de Minería, conteniendo como mínimo lo siguiente:

a. Nombre completo de la persona natural o jurídica y su representante legal en este último caso; domicilio; teléfono y correo electrónico.

b. Número de documento de identidad. 
c. En el caso de personas jurídicas, debe consignarse los datos de inscripción en los Registros Públicos y los datos de identificación de su representante legal; así como los correspondientes al otorgamiento de facultades.

d. Acreditación de la titularidad de todos sus derechos mineros conforme a las reglas establecidas en el Artículo 6 del presente Reglamento.

e. Resolución de autorización de inicio de actividades de exploración o explotación, emitida por la autoridad competente (Decreto Supremo No 013-2002EM, 2002).

La Dirección General de Minería emite la constancia que acredita la condición de Pequeño Productor Minero después de verificar que se cumplan con los requisitos que determina el artículo 91 del TUO de la LGM, dicha constancia tiene una vigencia de dos años (Decreto Supremo No 013-2002-EM, 2002).

Por último, de manera excepcional dentro del marco del Proceso de Formalización Minera Integral, se puede acreditar lo siguiente:

Excepcionalmente, y por única vez, la acreditación de la condición de pequeño productor minero o productor minero artesanal puede ser otorgada por el Ministerio de Energía y Minas al titular de la concesión minera que: (i) acredite contar con un Instrumento de Gestión Ambiental Correctivo (IGAC) o con un Instrumento de Gestión Ambiental para la Formalización de Actividades de Pequeña Minería y Minería Artesanal en curso (IGAFOM) debidamente aprobado por la autoridad competente; o, (ii) acredite haber suscrito contrato de cesión o explotación con el o los minero (s) que se encuentre (n) en el Registro Integral de Formalización, por un plazo no menor a tres (03) años (Decreto Legislativo $\mathrm{N}^{\circ}$ 1336, 2017).

\subsection{Minería ilegal y minería informal}

El proceso de formalización fue creado por el Estado Peruano para formalizar la actividad minera y para luchar contra la minería ilegal, debido a que las actividades mineras que no respetan la legislación vigente afectan significativamente de manera negativa ámbitos vitales para el desarrollo del país. 
Los impactos sociales y ambientales que genera la minería ilegal son los siguientes: la destrucción de bosques y de tierras agrícolas, la contaminación del agua, la evasión de impuestos, afecta el turismo, debilita la influencia de los Gobiernos Regionales y Locales y vulnera los derechos fundamentales de las personas implicadas en la actividad y de las zonas cercanas; estos derechos son a la integridad física y psíquica, trabajo libre, propiedad, paz, un ambiente equilibrado, libertad y salud; las prácticas más comunes son la trata de personas que conllevan a la explotación laboral y la explotación sexual.

Como indican (Torres \& Velarde, 2013) desde al año 2012 el Gobierno ha promulgado diversas normas jurídicas para luchar contra la minería ilegal, enfocados en los siguientes cuatro componentes:

"El primer componente está dirigido a fortalecer los procesos de interdicción de la minería ilegal. El segundo componente, dirigido a fortalecer la fiscalización ambiental. El tercer componente, está enfocado en los aspectos penales y de la pérdida de dominio. Por último, el cuarto componente está enfocado en regular un proceso que permita formalizar las actividades de minería ilegal, y así dar oportunidades a los mineros ilegales para realizar actividades conforme a la ley" (pág. 426).

Para una mayor comprensión de cómo funciona el Proceso de Formalización Minera Integral, primero de deben tener en claro los conceptos de minería informal y minería ilegal, así como cuales son sus diferencias.

El artículo 2 del D.L. N ${ }^{\circ} 1105$ define a la minería ilegal así:

Actividad minera ejercida por persona, natural o jurídica, o grupo de personas organizadas para ejercer dicha actividad, usando equipo y maquinaria que no corresponde a las características de la actividad minera que desarrolla (Pequeño Productor Minero o Productor Minero Artesanal) o sin cumplir con las exigencias de las normas de carácter administrativo, técnico, social y medioambiental que rigen dichas actividades, o que se realiza en zonas en las que esté prohibido su ejercicio. 
Sin perjuicio de lo anterior, toda actividad minera ejercida en zonas en las que esté prohibido el ejercicio de actividad minera, se considera ilegal.

Esta definición sustituye la definición de minería ilegal contenida en el artículo 3 del Decreto Legislativo No 1100.

Además, el mismo artículo 2 en el inciso b) define la minería informal de la siguiente manera:

Actividad minera que es realizada usando equipo y maquinaria que no corresponde a las características de la actividad minera que desarrolla (Pequeño Productor Minero o Productor Minero Artesanal) o sin cumplir con las exigencias de las normas de carácter administrativo, técnico, social y medioambiental que rigen dichas actividades, en zonas no prohibidas para la actividad minera y por persona, natural o jurídica, o grupo de personas organizadas para ejercer dicha actividad que hayan iniciado un proceso de formalización conforme se establece en el presente dispositivo (Decreto Legislativo $N^{\circ}$ 1105, 2012).

Como indica el anterior artículo, la diferencia principal entre la minería ilegal y la minería informal radica en que en el primer caso la actividad minera se debe desarrollar en una zona en la que esté prohibido su ejercicio. En cuanto a lo demás son bastante parecidas por el uso de equipos y maquinarias que no les corresponden, y el incumplimiento de las exigencias legales.

La correcta manera de ejercer actividad minera se considera minería formal, el D.L. $N^{\circ} 1336$ define en su artículo 2 lo que se debe entender por minería formal, siendo esta la "actividad ejercida por persona, natural o jurídica, que cuenta con autorización de inicio o reinicio de actividades de exploración, explotación y/o beneficio de minerales y/o título de concesión de beneficio emitida por la autoridad competente".

Además, le otorgó una nueva definición a la minería informal dentro del marco del vigente del PFMI:

Actividad minera realizada en zonas no prohibidas por aquella persona, natural o jurídica, que se encuentre inscrita en el Registro Integral de Formalización Minera cumpliendo con las normas de carácter administrativo y además, con las 
condiciones previstas en el artículo 91 del Texto Único Ordenado de la Ley General de Minería, aprobado por el Decreto Supremo Nº14-92-EM.

(Decreto Legislativo No 1336, 2017).

Ante la minería ilegal y la minería informal, el Estado Peruano ha promulgado diversos Decretos Legislativos en orden de protegerse y actuar contra dichas actividades, los cuales se mencionan a continuación:

- D.L. $\mathrm{N}^{\circ} 1100$, regula la interdicción de la minería ilegal en toda la República.

- D.L. $\mathrm{N}^{\mathrm{o}}$ 1101, establece medidas para el fortalecimiento de la fiscalización ambiental como mecanismo de lucha contra la minería ilegal.

- D.L. N 1102 , incorpora al Código Penal los delitos de minería ilegal.

- D.L. $\mathrm{N}^{\mathrm{o}} 1103$, establece medidas de control y fiscalización en la distribución, transporte y comercialización de Insumos Químicos utilizados en la Minería Ilegal.

- D.L. $\mathrm{N}^{\mathrm{o}} 1105$, disposiciones para el proceso de formalización de las actividades de pequeña minería y minería artesanal.

- D.L. $N^{o} 1106$, lucha eficaz contra el lavado de activos y delitos relacionados a la minería ilegal.

- D.L. $\mathrm{N}^{\mathrm{o}}$ 1107, establece medidas de control y fiscalización en la distribución, transporte y comercialización de maquinarias y equipos utilizados en la minería ilegal.

- D.L. $\mathrm{N}^{\mathrm{o}} 1244$, fortalece lucha contra el crimen organizado y la tenencia ilegal de armas.

- D.L. No 1293 , declara de interés nacional la formalización de las actividades de la pequeña minería y minería artesanal.

- D.L. $\mathrm{N}^{\mathrm{o}}$ 1336, establece disposiciones para el Proceso de Formalización Minera Integral.

Como señalan (Ipenza \& Delgado, 2012):

En estos últimos años estos impactos han aumentado y a su vez se han hecho más evidentes, sobre todo en algunas partes del país, y esto debido, en parte, al alza sostenida del precio de los minerales. La Explotación a la que se han sometido 
estos recursos ha sido, en gran parte, desordenada, descontrolada e insostenible (pág. 61).

Un kilo de oro puede llegar a costar en el mercado negro treinta y cinco mil dólares, con lo cual la venta de minerales extraídos ilegalmente puede generar millones de dólares al año (Cruz, 2017); eso significa una ganancia directa y mayor de la que se podría conseguir con el desarrollo de otras actividades, sobre todo teniendo en cuenta que la minería ilegal se propaga comúnmente en las zonas alejadas y con poca presencia del Estado.

La grandes cantidades de dinero que produce la minería ilegal le otorga el poder que necesitan sus líderes para intimidar a las autoridades regionales y locales; como también a las comunidades que se localizan en sus zonas de dominio.

Este no es problema que afecte exclusivamente al Perú, Latinoamérica se caracteriza actualmente por los altos porcentajes de oro extraído mediante actos ilegales; en torno del $28 \%$ del oro extraído en Perú, del $30 \%$ en Bolivia, más del $70 \%$ en Ecuador, del $80 \%$ en Colombia y el $80 \%$ en Venezuela es extraído de manera ilegal (Global Initiative against Transnational Organized Crime, 2016, pág. 2).

La minería ilegal emplea a cientos de miles de trabajadores en toda Latinoamérica, muchos de los cuales son extremadamente vulnerables a la explotación laboral y a la trata de personas (Global Initiative against Transnational Organized Crime, 2016, pág. 2).

Además de los efectos nocivos que produce la minería ilegal en las personas, el medio ambiente es el principal afectado a causa de la alta contaminación que se genera por la explotación minera, el vertimiento de los desechos mineros y la deforestación llevada a cabo para el desarrollo de la actividad.

Entre octubre del 2012 y octubre del 2016, la minería ilegal de oro ocasionó la deforestación de 12.500 hectáreas en los bosques de la Amazonía sur del país, con mayor fuerza en Madre de Dios. El cálculo que realizó el proyecto MAAP - a cargo de la Asociación para la Conservación de la Cuenca Amazónica (ACCA) y la Amazon 
Conservation Association (ACA) - se basó en imágenes de satélite capturadas durante los últimos cuatro años (García Delgado, 2016, pág. párr.1).

La depredación en la Amazonía alcanzó en el 2017 una zona comparable a 200 mil estadios de fútbol (143 mil 425 hectáreas), de acuerdo al Proyecto de Monitoreo de Amazonía Andina (MAAP). De esa manera, tanto la explotación ilegal de oro como las actividades agropecuarias han provocado que esta deforestación se asiente, de manera especial, en los departamentos de Ucayali y Madre de Dios (Contreras, 2018, pág. párr.1).

\subsection{Antecedentes del Proceso de Formalización Minera Integral}

En esta sección del presente capítulo, se va a desarrollar la evolución, siguiendo una línea de tiempo, de la legislación peruana sobre los procesos de formalización minera, así como también cuales han sido las normas jurídicas promulgadas, hasta llegar al vigente Proceso de Formalización Minera Integral.

El primer intento de formalización de las actividades mineras en el país comenzó en el año 2002 con la Ley No 27651, Ley de Promoción y Formalización de la Pequeña Minería y Minería Artesanal y su Reglamento, el D.S. No 013-2002-EM (Dirección General de Formalización Minera, 2017, pág. 44).

Al ser la primera norma jurídica sobre el tema, su objetivo era introducir en las normas minera un marco que permitiera la formalización, promoción y desarrollo de los pequeños productores y los productores artesanales, como señala el artículo 1 (Ley $\mathrm{N}^{\mathbf{o}}$ 27651, 2002).

Además, introdujo que los Gobiernos Regionales mediante las Direcciones Regionales de Energía y Minas ayudaran al establecimiento del acuerdo o contrato de explotación entre el Productor Minero Artesanal y el concesionario minero, así como una tutela continua para ayudar a su correcto desarrollo, según el artículo 11 (Ley No 27651, 2002) 
Años más adelante, el dieciocho de febrero de 2012 se publicó el D.L. № 1100 , que reguló la interdicción de la minería ilegal en la República y estableció reglas suplementarias. En sus primeros capítulos abarcó las prohibiciones en el ámbito de la pequeña minería y la minería artesanal.

E1 Decreto Legislativo No 1100 en su artículo 1 declara que "el Estado promueve el ordenamiento y la formalización con inclusión social de la minería a pequeña escala"; a su vez, el numeral 9.2 del artículo 9 del mismo cuerpo legal señala que "el Estado promueve y participa en la formalización de la minería en pequeña escala".

También se estableció que "no se llevarán a cabo acciones de adecuación, promoción o formalización de actividades mineras que se realicen en áreas sujetas a procedimientos especiales tales como Parques Nacionales, Santuarios Nacionales, Santuarios Históricos u otras zonas reservadas" según la quinta disposición complementaria del D.L. $\mathrm{N}^{\circ} 1100$.

Meses después, el diecinueve de abril de 2012 se publicó el D.L. N 1105 , que tenía como finalidad constituir disposiciones que complementaran la formalización minera, tanto para la pequeña minería como para la minería artesanal.

El artículo 3 determina que es lo que se debe entender por dicho proceso:

"El Proceso de Formalización de la Actividad Minera de Pequeña Minería y Minería Artesanal, es aquél mediante el cual se establecen y administran los requisitos, plazos y procedimientos para que el sujeto de formalización pueda cumplir con la legislación vigente.

El sujeto de formalización a que se refiere el párrafo anterior puede ser una persona natural, una persona jurídica o un grupo de personas organizadas para ejercer dicha actividad" (Decreto Legislativo N 1105, 2012).

Para iniciar o continuar correctamente el proceso de formalización, los sujetos debían cumplir con los pasos establecidos en el artículo 4 del D.L. N ${ }^{\circ} 1105$, los cuales son los siguientes:

- Presentar la Declaración de Compromiso. 
- Acreditar la titularidad, contrato de cesión o contrato de explotación sobre la concesión minera.

- Acreditar la propiedad o autorización de uso del terreno superficial.

- La autorización de uso de aguas.

- La aprobación del Instrumento de Gestión Ambiental Correctivo.

- Autorización para el inicio o reinicio de las actividades mineras.

El D.S. N 003-2013-EM, que se publicó el seis de febrero de 2013, estableció requerimientos para la formalización minera en el plano nacional, como la admisión a trámite o la cancelación de la declaración de compromisos, además de medidas indispensables para no perder la condición de minero informal.

El veinticuatro de agosto de 2013 se publicó el D.S. Nº32-2013-EM, que fortaleció el proceso de formalización minera y otorgó facilidades en los plazos para los sujetos inscritos en el proceso de formalización, así como programas de asistencia técnica y mencionó la importancia de una posterior estrategia de saneamiento.

A través de la Resolución Suprema N 340-2013-PCM, se constituyó la Comisión que se encargó de proponer la Estrategia de Saneamiento de la Pequeña Minería y de la Minería Artesanal.

Lo mencionado en el párrafo anterior es el antecedente del D.S. No 029-2014PCM, el cual se difundió el diecinueve de abril de 2014 y aprobó la Estrategia de Saneamiento, el artículo 1 aprobó los ejes y objetivos estratégicos, los cuales son: la afirmación de la formalización, la fiscalización, la reparación de las áreas afectadas y la atención social.

El artículo 2 determinó lo siguiente sobre el Registro de Saneamiento:

Serán objeto del Registro de Saneamiento aquellos mineros informales que al 19 de abril de 2014 cuenten con estatus de vigente en el Registro Nacional de Declaración de Compromisos del Ministerio de Energía y Minas.

Mediante Resolución Ministerial del sector Energía y Minas se aprobará el Registro de Saneamiento a los ciento veinte (120) días de concluido el proceso de formalización, considerando a los mineros informales señalados en el párrafo 
precedente que cumplan con la inscripción en el Registro Único de Contribuyentes (Decreto Supremo Nº29-2014-PCM, 2014).

La única disposición complementaria del D.L. № 1293 prorrogó el vigor de la Estrategia de Saneamiento hasta el término del plazo de ciento veinte días hábiles computados desde el seis de febrero de 2017, plazo que se encuentra señalado en el artículo 4 de dicha norma jurídica.

Luego, el treinta de diciembre de 2016 se publicó el D.L. N 1293, que declaró de interés nacional la formalización de las actividades de la pequeña minería y minería artesanal; como señala en su artículo 1, tuvo por "objeto declarar de interés nacional la reestructuración del proceso de formalización de las actividades de la pequeña minería y minería artesanal, el mismo que se regula en el Decreto Legislativo $N^{\circ} 1105$ ”.

El D.L. N ${ }^{\circ} 1293$ en el artículo 3 creó “el proceso de formalización minera integral de la pequeña minería y minería artesanal, a cargo de las Direcciones y/o Gerencias Regionales de Energía y Minas" y determinó que para su ejecución se debería crear el "Registro Integral de Formalización Minera, a cargo de la Dirección General de Formalización Minera del Ministerio de Energía y Minas”, lo que ocurrió más adelante.

El artículo 4 menciona quienes son los sujetos que forman parte del REINFO:

1. Los sujetos que cuenten con inscripción vigente en el Registro de Saneamiento, a que se refiere el artículo 2 del Decreto Supremo No 029-2014-PCM .

2. Los sujetos que formen parte del Registro Nacional de Declaraciones de Compromisos, con inscripción vigente, y que acrediten su inscripción en el RUC. 3. Excepcionalmente, las personas naturales que se encuentren desarrollando actividades de pequeña minería o de minería artesanal de explotación, que cumplan con las condiciones establecidas en el artículo 91 del Texto Único Ordenado de la Ley General de Minería, aprobado por el Decreto Supremo N ${ }^{\circ}$ 014-92-EM, y que además realicen su actividad en una sola concesión minera, a 
título personal y que cuenten con inscripción en el Registro Único de Contribuyentes $^{4}$ (Decreto Legislativo No 1293,2016 ).

El mismo artículo 4 el párrafo 4.5 regula que los sujetos que desarrollan actividad minera en zonas permitidas sin formar parte del proceso de formalización minera del D.L. No 1105 o del PFMI, se les aplica las sanciones de carácter administrativo, civil o penal que correspondan (Decreto Legislativo $\mathrm{N}^{\circ} 1293,2016$ ).

Además, la cuarta disposición complementaria final del D.S. № 018-2017-EM determina que los sujetos que se encontraban afiliados al Registro Nacional de Declaraciones de Compromisos o al Registro de Saneamiento, y que no lograron inscribirse en el REINFO hasta agosto de 2017, no se hallan dentro de la competencia del PFMI.

“El Proceso de Formalización Minera Integral tiene una vigencia de treinta y seis (36) meses, contados a partir de la culminación del plazo de inscripción señalado en el párrafo 4.2 del artículo 4" del presente D.L. № 1293, según el artículo 6. El plazo de inscripción mencionado anteriormente abarcó desde el seis de febrero de 2017 hasta ciento veinte (120) días hábiles después, es decir, hasta el primero de agosto de 2017, la vigencia de los treinta y seis meses recién empezó a correr al culminar dicho plazo.

\subsection{Pasos del Proceso de Formalización Minera Integral}

El D.L. $\mathrm{N}^{\mathrm{o}}$ 1336, publicado el seis de enero de 2017, tiene por "objeto establecer disposiciones para el proceso de formalización a efectos de que éste sea coordinado, simplificado y aplicable en el ámbito del territorio nacional”, según su artículo 1. En otras palabras, esta y sus demás normas jurídicas complementarias son las que se deben tener en cuenta para culminar satisfactoriamente el PFMI en cuanto a pasos y requisitos a seguir.

\footnotetext{
${ }^{4}$ Dichas inscripciones se realizaron a partir del 6 de febrero de 2017 hasta el 1 de agosto de 2017, ante la SUNAT.
} 
El artículo 2 del D.L. № 1336 define por primera vez la minería formal y lo hace como la "actividad ejercida por persona, natural o jurídica, que cuenta con autorización de inicio o reinicio de actividades de exploración, explotación y/o beneficio de minerales y/o título de concesión de beneficio emitida por la autoridad competente".

El artículo 3 determina cuales son los requisitos obligatorios a seguir para culminar el proceso:

3.1 La formalización minera integral, puede ser iniciada o continuada, por el sujeto inscrito en el Registro Integral de Formalización Minera que realiza su actividad cumpliendo con lo siguiente:

1. Aprobación del IGAFOM o del IGAC.

2. Acreditación de Propiedad o Autorización de Uso del Terreno Superficial.

3. Acreditación de Titularidad, Contrato de Cesión o Contrato de Explotación respecto de la concesión minera.

3.2 No será exigible la presentación del CIRA siendo suficiente la presentación de una Declaración Jurada sujeta a fiscalización posterior por parte del Ministerio de Cultura.

3.3 La Dirección y/o Gerencia Regional de Energía y Minas emite la autorización de inicio o reinicio de actividades mineras de explotación y/o beneficio de minerales y/o título de concesión de beneficio, considerando el cumplimiento de los requisitos citados en el presente artículo.

3.4 Los requisitos a que se refiere el presente artículo, pueden ser tramitados o acreditados de manera simultánea (Decreto Legislativo No 1336, 2017).

Meses después, se publicó el primero de junio de 2017 el Decreto Supremo No 018-2017-EM, que estableció mandatos complementarios para que se simplifiquen requisitos y se adquieran incentivos económicos dentro del PFMI. Dicha norma se aplica a quiénes sean parte del REINFO, según su artículo 2.

El artículo 3 creó el REINFO, cuyo texto es el que se encuentra a continuación:

3.1 Créase el Registro Integral de Formalización Minera de aplicación a nivel nacional y en el ámbito del Proceso de Formalización Minera Integral de la 
pequeña minería y de la minería artesanal, a cargo de la Dirección General de Formalización Minera del Ministerio de Energía y Minas.

3.2 La inscripción en el Registro constituye el único acto por el cual se da inicio al Proceso de Formalización Minera Integral. Los mineros informales son identificados en el Registro Integral de Formalización Minera, a través de su número de inscripción en el Registro Único de Contribuyentes.

3.3 A partir del 2 de agosto de 2017, el Registro Integral de Formalización Minera se constituye como el único registro que comprende a los mineros informales acogidos al Proceso de Formalización Minera Integral. En tal sentido, el Registro Nacional de Declaraciones de Compromisos y el Registro de Saneamiento pierden su vigencia, incorporándose su información al Registro Integral de Formalización Minera, previo cumplimiento de la inscripción en el Registro Único de Contribuyentes en concordancia con el numeral 3.2 anterior.

(Decreto Supremo No 018-2017-EM, 2017).

El Proceso de Formalización Minera Integral se inicia con la inscripción en el REINFO por parte de un minero informal; de esa manera, los mineros con inscripción vigente deben respetar los compromisos asumidos y entregar los requisitos exigidos para culminar con el proceso, según señala el artículo 7 del D.S. № 018-2017-EM.

La inscripción en el REINFO se pudo realizar de diversas formas, para ello el artículo 5 identifica quiénes son los sujetos que pueden integrarlo:

5.1 Los mineros informales con inscripción vigente en el Registro Nacional de Declaraciones de Compromisos establecido en el Decreto Legislativo $N^{\circ} 1105$ que al 1 de agosto de 2017 cuenten con el Registro Único de Contribuyentes de la SUNAT, integrando el Registro de Saneamiento.

5.2 Los mineros informales que al 1 de agosto de 2017 cuenten con inscripción vigente en el Registro de Saneamiento establecido en el Decreto Supremo 0292014-PCM, los cuales se integran automáticamente al REINFO.

5.3 Las personas naturales que desarrollan únicamente actividad minera de explotación, siempre que se inscriban ante la SUNAT hasta el 1 de agosto de 2017, de acuerdo a lo señalado en la Resolución de Superintendencia No 013 2017-SUNAT. 
5.4 Los titulares de concesiones mineras en áreas declaradas como zonas de exclusión minera siempre que cuenten con concesión vigente otorgada antes del 19 de febrero de 2010 (Decreto Supremo No 018-2017-EM, 2017).

El numeral 5.3 del artículo 5 del D.S. No 018-2017-EM hace alusión a las personas naturales que lograrían la inscripción por primera vez en un proceso de formalización minera, pero para ello solo calificaron quienes desarrollaban de manera única "actividad minera de explotación de conformidad con el numeral 3 del párrafo 4.1 del artículo 4 del Decreto Legislativo No 1293 ".

Dicho numeral 3 del párrafo 4.1 del artículo 4 del (Decreto Legislativo No 1293 , 2016), establece lo siguiente:

“3. Excepcionalmente, las personas naturales que se encuentren desarrollando actividades de pequeña minería o de minería artesanal de explotación, que cumplan con las condiciones establecidas en el artículo 91 del Texto Único Ordenado de la Ley General de Minería , aprobado por el Decreto Supremo No 014-92-EM, y que además realicen su actividad en una sola concesión minera, a título personal y que cuenten con inscripción en el Registro Único de Contribuyentes".

El plazo para la inscripción de las personas naturales que realicen actividad minera de explotación de la pequeña o artesanal minería ante la SUNAT fue de ciento veinte días hábiles, que se contaron desde el seis de febrero de 2017 hasta el primero de agosto de 2017, según lo señalado el artículo 4 del D.L. Nº 1293.

El artículo 5 Decreto Supremo No 018-2017-EM señala que la inscripción en el REINFO para las personas naturales mencionadas anteriormente era posible "siempre que se inscriban ante la SUNAT hasta el 1 de agosto de 2017, de acuerdo a lo señalado en la Resolución de Superintendencia Nº13-2017-SUNAT".

La Resolución de Superintendencia N ${ }^{\circ}$ 013-2017-SUNAT estableció en el artículo 3 el procedimiento de presentación de información a seguir para la inscripción en el REINFO: 
1. Ingresar al portal de la SUNAT y con el Código de Usuario y Clave SOL acceder a SUNAT Operaciones en Línea.

2. Ubicar la opción "Mi RUC y otros registros" y dentro de ella la sub opción "Registro de datos para el Registro Integral de Formalización Minera".

3. Incluir la información que en ella se indique y grabar la referida información, siguiendo las indicaciones que muestra el sistema. Una vez grabada la información, no se pueden efectuar actualizaciones ni modificaciones ${ }^{5}$.

Además, las personas naturales que aparecen en el párrafo 5.3 del artículo 5 del D.S. N ${ }^{\circ}$ 018-2017-EM, para lograr la inscripción en el REINFO debieron declarar bajo juramento que cumplían con los requisitos especiales que establece el artículo 6 del mismo cuerpo legal, los cuales son los siguientes:

a. Realizar actividad minera de explotación, a título personal y en un solo derecho minero.

b. Contar con inscripción en el RUC.

c. Desarrollar actividad minera con una antigüedad no menor de 05 años.

d. No contar con Declaración de Compromisos cancelada como consecuencia de no encontrarse desarrollando actividad minera.

e. No encontrarse inhabilitado para desarrollar actividad minera, de acuerdo a la legislación minera vigente.

f. No contar con inscripción vigente en el Registro Nacional de Declaraciones de Compromisos o en el Registro de Saneamiento.

(Decreto Supremo No 018-2017-EM)

Los requisitos especiales a los que hace referencia el artículo anterior se debieron declarar bajo juramento de acuerdo al formato del anexo I de la Resolución Ministerial No 056-2017-MEM-DM, dicha resolución abarca los siguiente temas: los datos de las persona naturales, datos del derecho minero y datos del área dónde se extiende la actividad minera.

\footnotetext{
${ }^{5}$ El artículo 4 de la misma resolución de la Sunat, señala que la SUNAT emite una Constancia de recepción de datos para el Registro Integral de Formalización Minera que contiene el detalle de lo informado.
} 
El artículo 5 del D.L. No 1293 regula que "la información recibida por la SUNAT es remitida al Ministerio de Energía y Minas dentro de los quince (15) días hábiles posteriores a la culminación del plazo de inscripción en el Registro Integral de Formalización Minera".

Las consecuencias obtenidas por los mineros informales con la inscripción en el REINFO se hallan reguladas en el artículo 7 del D.S. Nº18-2017-EM: son considerados mineros informales que inician el Proceso de Formalización Minera Integral, deben desarrollar actividad según los compromisos asumidos, presentar los requisitos necesarios, brindar información y otorgar facilidades a las autoridades competentes.

El plazo de la SUNAT para recibir inscripciones para el REINFO Minera venció el dos de agosto del 2017; los sujetos que no forman parte del REINFO tienen que paralizar sus actividades mineras, y dependiendo del caso, formalizarlas. Además, si continúan "realizando actividad minera son pasibles de las medidas y/o sanciones de carácter administrativo, civil y/o penal que correspondan”, según indica el artículo 8 del D.S. No 018-2017-EM.

El REINFO lo administra de manera exclusiva la Dirección General de Formalización Minera del MINEM; además, también es la entidad facultada para verificar, fiscalizar y modificar los datos, según el artículo 4 del D.S. No 018-2017-EM. El artículo 9 del mismo cuerpo legal, agrega que de necesitarlo "puede requerir el apoyo de los Gobiernos Regionales, a través de sus Direcciones Regionales de Energía y Minas".

El artículo 16 del D.S. No 018-2017-EM establece los supuestos para que se modifique la información que contiene el REINFO: subsanación de error material en los datos personales o relacionado con el derecho minero, subsanación de oficio, modificación de declaración respecto del derecho minero, cambio de titularidad, cambio por acumulación minera, entre otros. 
El artículo 9 del Decreto Supremo No 018-2017-EM señala lo siguiente sobre la verificación y fiscalización, y cual es el plazo otorgado para ello:

9.1 La verificación efectuada por la Dirección General de Formalización Minera del MINEM es aquella que se realiza respecto de los requisitos señalados para la inscripción de las personas naturales que desarrollan únicamente actividad minera de explotación, de conformidad a lo establecido en el párrafo 5.3 del artículo 5 del presente Decreto Supremo.

9.2 La Dirección General de Formalización Minera del Ministerio de Energía y Minas efectúa la fiscalización sobre la información contenida en el REINFO.

9.4 La verificación referida en el párrafo 9.1 del presente artículo se realiza hasta el 31 de julio de 2018, mientras que la fiscalización señalada en el párrafo 9.2 del presente artículo se desarrolla durante la vigencia del Proceso de Formalización.

Si el resultado de la fiscalización determina que la información presentada carece de veracidad, se puede generar la exclusión del minero informal REINFO; así como por las demás causales reguladas por el artículo 13 del D.S. No 018-2017-EM, como no desarrollar actividad minera, incumplir con los requisitos de la legislación vigente, desistimiento expreso, desarrollar actividad minera en áreas no permitidas, incumplimiento de las obligaciones ambientales, de seguridad y salud ocupacional, entre otros.

Actualmente se puede consultar en la página web del MINEM (www.gob.pe/minem) ${ }^{6}$ a los mineros informales del proceso de formalización y que se encuentran en el REINFO.

En otro ámbito, el Decreto Legislativo $\mathrm{N}^{\circ} 1336$ creó los incentivos económicos en los ámbitos del derecho de vigencia y el pago de penalidades para incentivar a los titulares del régimen general a pactar con los mineros informales, de esta manera el Proceso de Formalización Minera Integral se vuelve más atractivo.

6 El link específico de la búsqueda en el REINFO es el siguiente: http://www.minem.gob.pe/_detalle.php?idSector=20\&idTitular=8049\&idMenu=sub8048\&idCateg=1442 
En el primer caso, el titular de la concesión minera del régimen general debe cancelar por derecho de vigencia como si fuera un pequeño productor por el plazo de tres años si suscribe un contrato de explotación o cesión minera por tres años con un minero informal inscrito en el REINFO; en el segundo caso, el titular no debe pagar penalidades por ese mismo plazo, según indican los artículos 19 y 20 del D.L. № 1336.

El artículo 22 del D.S. $N^{\circ}$ 018-2017-EM determina que se debe presentar ante el INGEMMET para obtener los beneficios económicos antes mencionados la inscripción en la SUNARP del contrato de explotación o de cesión minera entre el concesionario minero y el minero informal.

Otro punto importante del PFMI es la eliminación como requisito del CIRA, el Decreto Legislativo $N^{\circ} 1336$ señala en el párrafo 3.2 del artículo 3 que "no será exigible la presentación del Certificado de Inexistencia de Restos Arqueológicos, siendo suficiente la presentación de una Declaración Jurada sujeta a fiscalización posterior por parte del Ministerio de Cultura".

Lo mencionado anteriormente cambió lo regulado por el artículo 4 del D.L. $\mathrm{N}^{\mathrm{o}}$ 1105, que ordenó al Ministerio de Cultura que creara un procedimiento simplificado para el CIRA respecto de la zona donde se desarrollada el proyecto minero; lo cual ocurrió con el D.S. N 003-2013-MC, como se expone en el Capítulo III.

Adicionalmente, en los últimos meses se establecieron dos medidas nuevas aplicables al Proceso de Formalización Minera Integral, el primero publicado el veintinueve de junio de 2018, mediante el Decreto de Urgencia № 008-2018, amplió el plazo para cancelar el derecho de vigencia y la penalidad, en el artículo 1 regula lo siguiente:

Ampliar hasta el 30 de setiembre de 2018, la oportunidad de pago de las obligaciones contenidas en los artículos 39 y 40 del Texto Único Ordenado de la Ley General de Minería, aprobado por Decreto Supremo No 014-92-EM, correspondientes al año 2018 de aquellos titulares mineros que cumplen con los requisitos legales para ser considerados pequeño productor minero y productor 
minero artesanal según lo dispuesto en el artículo 91 del Texto Único Ordenado antes indicado.

En la introducción del mencionado Decreto de Urgencia, se explica que de acuerdo a las normas especiales del pequeño productor y el productor artesanal, al no pagar el Derecho de Vigencia pierden las concesiones mineras que hayan obtenido, lo cual perjudica el avance del Proceso de Formalización Minera Integral sobre dichos titulares, razón por la cual amplían el mencionado plazo. Una vez más, el estado priorizó la formalización minera sobre el respeto de las normas jurídicas mineras y sus obligaciones.

El segundo y más reciente, lo regula la Resolución Ministerial № 289-2018MEM/DM, difundida el veintisiete de julio de 2018, que autoriza que se emita un carné de identificación, en su artículo 1 indica lo siguiente:

Autorizar la emisión del Carné de Identificación del minero en vías de formalización con inscripción vigente en el REINFO, y en el ámbito del proceso de formalización minera integral de la pequeña minería y minería artesanal. La entrega del Carné de Identificación del minero en vías de formalización es efectuada en forma progresiva, priorizando las zonas donde exista una mayor densidad de inscripciones en el citado registro.

\subsubsection{Aprobación del Instrumento de Gestión Ambiental y Fiscalización para la Formalización de Actividades de Pequeña Minería y Minería Artesanal o del Instrumento de Gestión Ambiental Correctivo}

El Instrumento de Gestión Ambiental para la Formalización de Actividades de Pequeña Minería y Minería Artesanal (IGAFOM) y el Instrumento de Gestión Ambiental Correctivo (IGAC) son distintos Instrumentos de Gestión Ambiental.

El IGAC fue constituido en abril de 2012 por el D.L. N ${ }^{\circ} 1105$. En el mes de septiembre del mismo año, mediante D.S. N ${ }^{\circ}$ 004-2012-MINAM, se acogieron las disposiciones complementarias. 
Los objetivos del IGAC son aplicar la política y leyes ambientales en la formalización minera y establecer las obligaciones de los sujetos de formalización para la prevención, el control y la reparación de los impactos ambientales, dependiendo de cada caso, según regula el artículo 6 del D.S. Nº04-2012-MINAM.

Continuando con el segundo Instrumentos de Gestión Ambiental, el IGAFOM, se constituyó en enero de 2017 por el D.L. N ${ }^{\text {o }}$ 1336; su objetivo es la adecuación de las actividades de la artesanal y pequeña minería a las normas ambientales vigentes para reconocer, controlar, aplacar y prevenir los impactos negativos, según el artículo 3 del D.S. No 038-2017-EM.

El artículo 9 regula el trámite del IGAC:

9.1 El minero informal inscrito en el REINFO que tenga en trámite un Instrumento de Gestión Ambiental Correctivo establecido en el Decreto Supremo No 0042012-MINAM, puede desistirse del mismo y acogerse al instrumento ambiental establecido en la presente norma; o, en su defecto, culminar el referido trámite ante la autoridad correspondiente.

9.2 El IGAC o la Declaración de Impacto Ambiental debidamente aprobada por la autoridad competente, puede sustituir la exigencia de contar con el IGAFOM. 9.3 Lo dispuesto en el presente artículo sólo es aplicable a los mineros informales inscritos en el Registro Nacional de Declaraciones de Compromisos o en el Registro de Saneamiento, y que posteriormente se incorporan al REINFO. (Decreto Legislativo No 1336, 2017).

Para complementar el IGAFOM del Decreto Legislativo antes mencionado, en octubre del 2017 se publicó el D.S. N 038-2017-EM, Decreto Supremo que estableció Disposiciones Reglamentarias para el IGAFOM. Además, la autoridad competente para aprobar el IGAFOM es la Dirección Regional de Energía y Minas competente; en Lima Metropolitana, es la Dirección General de Asuntos Ambientales Mineros.

La primera Disposición Complementaria Transitoria del D.S. № 038-2017-EM, señala que "el minero informal puede sustituir la exigencia de contar con el IGAFOM en 
el marco del Proceso de Formalización Minera Integral, acreditando la aprobación del IGAC o de la Declaración de Impacto Ambiental, los cuales deben encontrarse vigentes”.

Los dos aspectos que tiene el IGAFOM son el correctivo y el preventivo, el artículo 7 del D.S. N ${ }^{\circ}$ 038-2017-EM señala la información que debe contener cada uno de estos aspectos:

7.3 El Aspecto Correctivo contiene como mínimo lo siguiente:

Información General de la actividad de explotación y/o beneficio desarrollada; actividad minera según el método de explotación y/o beneficio; descripción de la situación actual; plan de manejo ambiental; medidas de cierre y post cierre; cronograma de implementación de las medidas de manejo ambiental.

7.4 El Aspecto Preventivo contiene como mínimo lo siguiente:

Actividad minera según el método de explotación y/o beneficio; línea base; identificación y evaluación de impactos ambientales; plan de manejo ambiental; plan de monitoreo y control; medidas de cierre y post cierre; cronograma de implementación de las medidas de manejo ambiental y los anexos.

(Decreto Supremo No 038-2017-EM, 2017).

Las etapas del procedimiento de evaluación del IGAFOM son las siguientes y en este específico orden: presentación del formato del aspecto correctivo, presentación del formato del aspecto preventivo, evaluación y por último, el pronunciamiento de la autoridad, según el artículo 8 del D.S. Nº38-2017-EM.

El formato correspondiente al aspecto correctivo es presentado por el minero informal ante la autoridad competente; luego, sin exceder los tres meses posteriores se debe presentar el aspecto preventivo ${ }^{7}$, de no haberse culminado la implementación de medidas ambientales consideradas en el primero, se debe incorporar en el segundo. En ambos casos, la Unidad de Recepción Documental deja constancia de la presentación con el sello oficial de recepción en una copia de los formatos, luego lo remite a la Oficina de

\footnotetext{
${ }^{7}$ Para el artículo 14 del Decreto Supremo No 038 -2017-EM es causal de abandono del procedimiento para la evaluación del IGAFOM, el incumplimiento de la presentación del formato del aspecto preventivo dentro del plazo establecido.
} 
Ventanilla Única para su ingreso al Sistema de Ventanilla Única, según los artículo 9 y 10 del Decreto Supremo Nº38-2017-EM.

La evaluación del IGAFOM se realiza de la siguiente manera, como indica el artículo 11 del Decreto Supremo No 038-2017-EM:

1.La evaluación previa se realiza en un plazo máximo de treinta (30) días hábiles contados a partir del día siguiente de la recepción del formato del Aspecto Preventivo.

2.La autoridad ambiental evalúa el IGAFOM en un plazo de quince (15) días hábiles y de ser el caso, formular las observaciones.

3.El minero informal tiene un plazo de diez (10) días hábiles para subsanar las observaciones.

4.La autoridad competente emite el pronunciamiento que aprueba o desaprueba el IGAFOM en el plazo máximo de cinco (05) días hábiles.

El Decreto Supremo No 038-2017-EM establece en su artículo 12 las opiniones favorables que se necesitan para la aprobación del IGAFOM:

- Del Servicio Nacional de Áreas Naturales Protegidas por el Estado (SERNANP) respecto de las actividades mineras desarrolladas en zonas de amortiguamiento de Áreas Naturales Protegidas.

- Del ANA y SERFOR, respecto de las actividades mineras desarrolladas en concesiones mineras superpuestas a concesiones forestales.

Además, el mismo artículo 12 describe que en caso las entidades antes mencionadas adviertan observaciones, son trasladadas a la Dirección Regional de Energía y Minas para que el minero informal sea notificado y pueda subsanarlas; luego, "el SERNANP, la ANA y/o SERFOR, cuando corresponda, emiten la opinión en el plazo de diez (10) días hábiles después de recibida la subsanación efectuada por el/la minero/a informal" (Decreto Supremo No 038-2017-EM).

En enero de 2018, la ANA aprobó los formatos para el procedimiento de evaluación del "Instrumento de Gestión Ambiental para la Formalización de Actividades 
de Pequeña Minería y Minería Artesanal (IGAFOM)", mediante la Resolución Jefatural No 035-2018-ANA.

De regreso al IGAFOM, una vez que este fue evaluado, la autoridad competente emite el acto administrativo que aprueba o desaprueba dicho instrumento, como señala el artículo 13 no puede faltar la siguiente información:

13.1 Nombre completo de la persona natural o jurídica inscrita en el REINFO.

13.2 Número de RUC con el que se encuentra inscrito en el REINFO.

13.3 Descripción de la actividad minera.

13.4 Polígono del (las) área (s) precisada (s) en el IGAFOM, en sistema de coordenadas UTM DATUM WGS-84 y zona, incluyendo el nombre y código del derecho minero.

13.5 Cronograma de implementación de las medidas de manejo ambiental del Aspecto Correctivo.

13.6 Precisar que el acto administrativo se expide en el marco del Proceso de Formalización Minera Integral.

13.7 El acto administrativo debe estar debidamente motivado por un informe técnico legal (Decreto Supremo No 038-2017-EM, 2017).

Las medidas de cierre se encuentran establecidas en los dos aspectos del IGAFOM, tanto en el correctivo como en el preventivo, con el objetivo que el impacto generado por la actividad minera no genere una contaminación ambiental posterior o de afectación a la salud de las población, según el artículo 16 del D.S. Nº 038-2017-EM.

El artículo 17 del D.S. Nº38-2017-EM regula la fiscalización que se desarrolla sobre el IGAFOM por parte de la Entidad de Fiscalización Ambiental competente; además, la OEFA puede acompañar a las supervisiones de la EFA. A su vez, el artículo 8 del Decreto Legislativo $\mathrm{N}^{\circ}$ 1336, le otorga a OEFA la facultad de brindar "asistencia técnica a las autoridades ambientales regionales competentes en materia de fiscalización y supervisión ambiental aplicable a la pequeña minería y minería artesanal”.

Mediante Resolución Ministerial No 473-2017-MEM-DM, en noviembre de 2017, se aprobaron los formatos del aspecto correctivo y preventivo del IGAFOM, se 
incluyeron en modo de anexos y junto al catálogo de medidas ambientales, se encuentran publicados en el Portal Institucional del MINEM.

El artículo 2 de la Resolución Ministerial No 473-2017-MEM-DM, regula que "las medidas contenidas en el Plan de Manejo Ambiental y declaradas en los formatos del Aspecto Correctivo del IGAFOM, deben ser implementadas durante la vigencia del Proceso de Formalización Minera Integral”.

\subsubsection{Acreditación de propiedad o autorización de uso del terreno superficial}

La acreditación de propiedad o autorización de uso del terreno superficial que se encuentra sobre el área de la concesión minera es un requisito indispensable para completar satisfactoriamente el PFMI y así poder desarrollar actividad minera de manera legal.

Como se mencionó antes, el numeral 2 del párrafo 3.1 del artículo 3 del D.L. $\mathrm{N}^{\mathrm{o}}$ 1336 lo señala como un requisito para la culminación de proceso; la misma ley, en el artículo 11 regula la manera en que se debe acreditar el terreno superficial, el texto es el siguiente:

11.1 El minero informal inscrito en el REINFO puede presentar la declaración jurada con firma legalizada ante notario público, donde:

a) Indique que es propietario o que está autorizado por el (los) propietario(s) del $100 \%$ de las acciones y derechos del predio.

b) Indique que se encuentre desarrollando actividad minera de explotación sobre terreno eriazo del Estado.

11.2 La presentación de la documentación antes mencionada, según corresponda, se efectúa ante el Gobierno Regional competente, quien posteriormente realiza la verificación de lo declarado.

11.3 Lo señalado en el presente artículo, constituye merito suficiente para acreditar lo señalado en el numeral 2 del párrafo 3.1 del artículo 3 del presente Decreto Legislativo.

11.4 Mediante Decreto Supremo del Ministerio de Agricultura y Riego refrendado por el Ministerio de Energía y Minas y el Ministerio de Cultura, se establecen las 
reglas de acreditación de la autorización de uso de terreno superficial en aquellas zonas donde existan comunidades campesinas o nativas, o áreas con bosques que integren el patrimonio nacional forestal y de fauna silvestre circunscrito en la Amazonía. SERFOR es la entidad encargada de emitir la autorización de uso de terreno superficial en áreas comprendidas dentro de la Amazonia.

(Decreto Legislativo No 1336, 2017).

Se pueden dar tres supuestos distintos: acreditar la propiedad sobre el terreno superficial, acreditar el uso superficial o acreditar que se encuentra en terreno eriazo del Estado.

En primer lugar, según el artículo 18 se puede probar la propiedad del terreno superficial con uno de estos documentos:

Declaración Jurada con firma legalizada ante notario público donde indique que es propietario, conforme al inciso a) del párrafo 11.1 del artículo 11 del Decreto Legislativo $\mathrm{N}^{\mathrm{o}} 1336$.

Número de la partida registral y Oficina Registral donde conste inscrito el derecho de propiedad sobre el terreno superficial.

Copia legalizada del título de propiedad con fecha cierta que acredite su calidad de propietario.

(Decreto Supremo No 018-2017-EM).

En segundo lugar, el mismo artículo 18 indica como se puede acreditar el uso del terreno superficial:

Declaración jurada suscrita por el minero informal (o en caso de ser persona jurídica, debe ser suscrita por su representante, debiendo precisarse el número del asiento donde se encuentren inscritas las facultades de su representación), a través de la cual indique que está autorizado por el propietario del 100\% de las acciones y derechos del predio y su localización geográfica en el sistema de coordenadas UTM DATUM WGS-84. Las firmas del minero informal y del propietario del predio deben estar legalizadas ante notario público. 
Copia legalizada del documento de fecha cierta, mediante el cual el propietario del terreno superficial otorga al minero informal el uso del área donde desarrolla la actividad minera.

Número de la partida registral y Oficina Registral donde conste inscrito el documento mediante el cual el propietario del predio autoriza al minero informal a utilizar el (los) terreno(s) donde se ubica el desarrollo de las actividades mineras; o, en su defecto, el testimonio de escritura pública del contrato por medio del cual se autoriza dicho uso.

(Decreto Supremo No 018-2017-EM)

Por último, según el mencionado artículo 18, el minero informal puede acreditar que se encuentra en un terreno eriazo del Estado de la siguiente manera:

Declaración Jurada con firma legalizada del minero informal indicando que se encuentra en un terreno eriazo del Estado y señalando la localización geográfica en el sistema de coordenadas UTM DATUM WGS-84 respecto del área donde viene desarrollando la actividad minera de explotación.

Certificado negativo de búsqueda catastral.

(Decreto Supremo No 018-2017-EM)

\subsubsection{Acreditación de titularidad, contrato de cesión o contrato de explotación respecto de la concesión minera}

Un requisito indispensable para completar satisfactoriamente el proceso de formalización y conseguir la declaración de minero firmal: es la acreditación de titularidad, contrato de cesión o contrato de explotación respecto de la concesión minera. El D.L. No 1336 lo señala como tal en su artículo 3.

El artículo 162 del TUO de la LGM determina que: "Los contratos mineros se rigen por las reglas generales del derecho común, en todo lo que no se oponga a lo establecido en la presente Ley". Asimismo, el artículo 163 agrega que deben ser inscritos en el Registro Público de Minería (Decreto Supremo Nº14-92-EM). 
En relación al presente requisito, en primer lugar, la definición que le otorga el TUO de la LGM al contrato de cesión minera es el siguiente: "El concesionario podrá entregar su concesión minera, de beneficio, labor general o transporte minero a tercero, percibiendo una compensación. El cesionario se sustituye por este contrato en todos los derechos y obligaciones que tiene el cedente ${ }^{8}$.

En segundo lugar, el artículo 18 del Reglamento de la Ley $\mathrm{N}^{\circ} 27651$, define el contrato de explotación minera de la siguiente manera:

Por el acuerdo o contrato de explotación el titular de un derecho minero autoriza a personas naturales o jurídicas a desarrollar actividad minera artesanal para extraer minerales en una parte o en el área total de su concesión minera, a cambio de una contraprestación.

El acuerdo o contrato de explotación celebrado constituye un requisito alternativo a la tenencia de derechos mineros para acreditar la condición de Productor Minero Artesanal según lo previsto en el Artículo 91 del TUO.

(Decreto Supremo No 013-2002-EM).

El titular de una concesión minera puede celebrar uno o más acuerdos o contratos de explotación ${ }^{9}$ sobre su derecho minero, según indica el artículo 21 del mismo D.S. No 013-2002-EM.

Del D.S. No 018-2017-EM, como indica el numeral (ii) del párrafo 1.2 de su artículo 1, uno de sus objetos es establecer las formas de acreditación del presente requisito.

El artículo 20 señala que el minero informal inscrito en el REINFO puede acreditar la titularidad, contrato de cesión o contrato de explotación respecto de la concesión minera de la siguiente manera:

\footnotetext{
${ }^{8}$ Las partes del contrato de cesión minera son el concesionario o cedente, y el llamado, tercero o cesionario; las leyes no regulan un lapso mínimo ni máximo para su duración, pero sí debe tener un carácter temporal. Asimismo, el contrato debe encontrarse en Escritura Pública e inscrito en el Registro Público correspondientes para que surja efectos contra terceros. Lastres, E. (2009). Los contratos mineros. Círculo de Derecho Aministrativo, número (8), 11-23.

${ }^{9}$ Para que el contrato de explotación surta efectos frente a terceros debe estar inscrito en Registros Públicos según indica el artículo 106 del TUO. Asimismo, de suscribirse el contrato, el titular de la concesión minera quedará exento "de la responsabilidad solidaria respecto de las obligaciones ambientales, de seguridad y salud en el trabajo que asume el minero interesado en su formalización”, conforme al artículo 6 del D.L. egislativo $\mathrm{N}^{\mathrm{o}} 1105$.
} 
20.1 En caso de ser titular de la concesión minera, indicar el número de partida registral y Oficina Registral de la SUNARP donde conste inscrita la titularidad. 20.2 En caso de no ser titular de la concesión minera, indicar el número de partida registral y Oficina Registral de la SUNARP donde conste inscrito el contrato de cesión minera o contrato de explotación.

El título de concesión minera no autoriza por sí mismo a realizar las actividades mineras de exploración ni explotación. Para tal efecto, se requiere de las medidas administrativas o títulos habilitantes establecidos por la normativa vigente ${ }^{10}$ (Decreto Supremo Nº18-2017-EM, 2017).

\subsubsection{Autorización de inicio o reinicio de actividades mineras de explotación y/o beneficio de minerales, y/o título de concesión de beneficio}

El principal requisito para culminar satisfactoriamente el PFMI es la Autorización de inicio o reinicio de actividades mineras de explotación y/o beneficio de minerales, y/o título de concesión de beneficio, se encuentra regulado en el numeral 3.3 del artículo 3 del D.L. No 1336; la autoridad facultada para emitirlo es la La Dirección y/o Gerencia Regional de Energía y Minas.

Asimismo, uno de los objetos del Decreto Supremo No 018-2017-EM es establecer las formas en las que se debe acreditar el presente requisito, así lo indica el numeral (iii) del párrafo 1.2 del artículo 1.

Se necesita la autorización administrativa que emite la Dirección Regional de Energía y Minas para iniciar o reiniciar las actividades mineras, el artículo 29 señala lo siguiente:

La autorización antes referida consiste en la verificación del cumplimiento de los requisitos previstos en el Decreto Legislativo $\mathrm{N}^{\mathrm{o}} 1336$, siendo estos los siguientes:

a) Acreditación de Propiedad o autorización de uso del terreno superficial, de acuerdo al Título III del presente Decreto Supremo.

\footnotetext{
${ }^{10}$ Dichas medidas administrativas se encuentran mencionadas en el Capítulo III.
} 
b) Acreditación de Titularidad, contrato de cesión o contrato de explotación respecto de la concesión minera, de acuerdo al Título IV del presente Decreto Supremo.

c) Presentación de Declaración jurada de Inexistencia de restos arqueológicos, de acuerdo al párrafo 3.2 del artículo 3 del Decreto Legislativo $\mathrm{N}^{\mathrm{o}} 1336^{11}$.

d) Aprobación del IGAFOM o del IGAC.

e) Presentación del Expediente Técnico.

(Decreto Supremo No 018-2017-EM, 2017).

El Expediente Técnico contiene información, con carácter de declaración jurada, que se estructura según si es una sustancia metálica o no, de acuerdo a la naturaleza de la actividad; además, se debe verificar en el campo que las actividades que realice el minero informal hagan referencia a la misma área y derecho que declaró, conformes los artículos artículos 30, 31 y 32 del D.S. No 018-2017-EM.

Si se emitiera la autorización mencionada sin cumplir con verificar la veracidad de la información que presentó el minero informal, la autoridad competente debe declarar la nulidad según lo regulado en el TUO de la Ley del Procedimiento Administrativo General.

La evaluación y fiscalización la debe realizar la Dirección Regional de Energía y Minas, para establecer la competencia el artículo 33 determina los siguientes criterios:

33.1 Cuando la actividad minera se desarrolla en un derecho minero, es competente la Región donde se ubica el $100 \%$ de ese derecho;

33.2 Cuando la actividad minera se desarrolla en un determinado derecho minero ubicado en dos o más Regiones, es competente la Región donde se efectúa dicha actividad; o,

33.3 Cuando la actividad minera y el derecho minero se desarrolle y ubique respectivamente, en dos o más Regiones, es competente la Región en la que se efectúe el mayor porcentaje de la actividad minera.

11 Ya no se exige la presentación del CIRA, sino solo una Declaración Jurada que luego podrá ser fiscalizada. 
(Decreto Supremo Nº18-2017-EM, 2017).

El artículo 34 indica que la autorización que otorga la Dirección Regional de Energía y Minas de inicio o reinicio de actividades mineras debe contener la siguiente información:

- Nombre completo de la persona natural o jurídica.

- Número de RUC.

- Localización geográfica.

- Tipo de sustancia que explota y/o beneficia.

- Condición de pequeña minería o minería artesanal.

- Capacidad de producción.

- Reconocer al sujeto jurídico como Minero Formal.

(Decreto Supremo Nº18-2017-EM, 2017)

El PFMI culmina cuándo la Dirección Regional de Energía y Minas correspondiente, expide la resolución de Autorización de inicio o reinicio de actividades de explotación, beneficio de minerales y/o título de concesión de beneficio. Para que eso ocurra, primero debe verificar que se acrediten todos los requisitos del Decreto Legislativo $\mathrm{N}^{\mathrm{o}}$ 1336, con la emisión de la autorización señalada, se declara a la persona natural o jurídica como Minero Formal, según el artículo 35 del D.S. Nº 018-2017-EM.

\subsection{Delitos de minería ilegal}

Ante los problemas generados por la minería ilegal y la urgencia de combatirlos, el veintinueve de febrero de 2012 se publicó el D.L. No 1102 , Decreto Legislativo que incorporó al Código Penal los delitos de minería ilegal mediante los artículos 307-A, 307B, 307-C, 307-D, 307-E y 307-F; además, modificó otros artículos agregando lo referente a la minería ilegal, como el artículo 314-D.

El Capítulo I del Título XIII del Código Penal, que regula los delitos de contaminación, comienza con los delitos de contaminación del medio ambiente, el manejo de residuos sólidos y el tráfico ilegal de residuos peligrosos.

El delito de minería ilegal se encuentra en el artículo 307-A del Código Penal: 
El que realice actividad de exploración, extracción, explotación u otro acto similar de recursos minerales metálicos y no metálicos sin contar con la autorización de la entidad administrativa competente que cause o pueda causar perjuicio, alteración o daño al ambiente y sus componentes, la calidad ambiental o la salud ambiental, será reprimido con pena privativa de libertad no menor de cuatro ni mayor de ocho años y con cien a seiscientos días-multa.

La misma pena será aplicada al que realice actividad de exploración, extracción, explotación u otro acto similar de recursos minerales metálicos y no metálicos que se encuentre fuera del proceso de formalización, que cause o pueda causar perjuicio, alteración o daño al ambiente y sus componentes, la calidad ambiental o la salud ambiental.

Si el agente actuó por culpa, la pena será privativa de libertad, no mayor de tres o con prestación de servicios comunitarios de cuarenta a ochenta jornadas.

(Decreto Legislativo $\mathrm{N}^{\circ} 635,1991$ ).

La única Disposición Complementaria Final del Decreto Legislativo $\mathrm{N}^{\circ} 1351$, dispuso que se encuentran libres de la responsabilidad penal de cometer el delito de minería ilegal: quién se localiza inscrito en el REINFO y no logra conseguir "la autorización final de inicio o reinicio de operaciones mineras por culpa inexcusable o negligente del funcionario a cargo".

De regreso al delito de minería ilegal, las formas agravadas se encuentran en el artículo 307-B, cuyo texto es el siguiente:

La pena será no menor de ocho años ni mayor de diez años y con trescientos a mil días-multa, cuando el delito se comete en uno de los siguientes supuestos:

1. En zonas no permitidas.

2. En áreas naturales protegidas o en tierras de comunidades nativas.

4. Emplea instrumentos capaces de poner en peligro la vida, la salud o el patrimonio.

5. Si se afecta aguas destinadas al consumo humano.

6. Aprovecharse de la condición de funcionario público.

7. Emplear menores de edad.

(Decreto Legislativo $\mathrm{N}^{\circ}$ 635, 1991). 
Además, el Código Penal regula en el artículo 307-C el delito de financiamiento de la minería ilegal, con una "pena privativa de libertad no menor de cuatro años ni mayor de doce años y con cien a seiscientos días-multa"; en el artículo 307-D, el delito de obstaculización de la fiscalización administrativa, con una "pena privativa de la libertad no menor de cuatro años ni mayor de ocho años" para quien "obstaculiza o impide la actividad de evaluación, control y fiscalización de la autoridad administrativa relacionada con la minería ilegal”; y en el artículo 307-E, el delito de tráfico ilícito de insumos químicos y maquinarias destinados a minería ilegal, con una "pena privativa de libertad no menor de tres años ni mayor de seis años y con cien a seiscientos días-multa" D.L. $\mathrm{N}^{\circ}$ 635 (1991).

El sujeto que cometa cualquiera de los delitos antes mencionados quedará inhabilitado "para obtener, a nombre propio o a través de terceros, concesiones mineras, de labor general, de beneficio o transporte de minerales metálicos o no metálicos, así como para su comercialización, por un periodo igual al de la pena principal”, según el artículo 307-F del Código Penal.

El artículo 4 del D.L. N ${ }^{\circ}$ 1244, modificó el artículo 3 de la Ley contra el Crimen Organizado, y añadió el numeral 15 que incluyen los “delitos ambientales, en las modalidades delictivas tipificadas en los artículos 307-A, 307-B, 307-C, 307-D y 307-E , 310-A, 310-B y 310-C del Código Penal" como un delito cometido por una organización criminal.

El delito de usurpación protege a los concesionarios mineros contra las invasiones mineras que sufren por parte de los mineros informales dentro del terreno de su concesión mineras ya que esta última es un bien inmueble parte de su propiedad.

El artículo 202 del Código Penal, regula el delito de usurpación de la siguiente manera:

Será reprimido con pena privativa de libertad no menor de dos ni mayor de cinco años:

1. El que, para apropiarse de todo o en parte de un inmueble, destruye o altera los linderos del mismo. 
2. El que, con violencia, amenaza, engaño o abuso de confianza, despoja a otro, total o parcialmente, de la posesión o tenencia de un inmueble o del ejercicio de un derecho real.

3. El que, con violencia o amenaza, turba la posesión de un inmueble.

4. El que, ilegítimamente, ingresa a un inmueble, mediante actos ocultos, en ausencia del poseedor o con precauciones para asegurarse el desconocimiento de quienes tengan derecho a oponerse.

La violencia a la que se hace referencia en los numerales 2 y 3 se ejerce tanto sobre las personas como sobre los bienes (Decreto Legislativo $\mathrm{N}^{\circ} 635,1991$ ).

Las Fiscalías Especializadas en Materia Ambiental (FEMA) del Ministerio Público son las entidades competentes de investigar los delitos que se encuentran en el Título XIII del Código Penal, que incluye los ambientales, de minería ilegal y contra los recursos naturales. Trabajan de manera armoniosa con las demás instituciones públicas competentes y trabajan a cargo de un Fiscal Provincial que se especializa en el tema (Ministerio Público, 2018).

En caso que las FEMA acusen la comisión de los delitos ambientales y de minería ilegal, el Poder Judicial desarrollará los procesos judiciales y sancionará por medio de los Juzgados Ambientales; ambas entidades podrán contar con el soporte de la Dirección ejecutiva de protección del medio ambiente de la Policía Nacional del Perú (DIREJMA), en caso de ser necesario.

Otras entidades estatales a las cuales se puede recurrir en caso de presenciar actividad minera ilegal es la Dirección Regional de Energía y Minas competente, el MINEN y la OEFA.

\subsection{Legislación comparada}

A nivel mundial son muchos los países que destacan en cuánto a la magnitud e importancia de sus industrias mineras, siendo algunos de estos los siguientes: China, Australia, Estados Unidos, Canadá y Rusia. Sin embargo, en dichos países son las grandes empresas mineras las que desarrollan en su mayoría la actividad productiva minera y por ende, poseen una gran capacidad económica; situación que dista mucho de la realidad 
Peruana, dónde la pequeña minería, la minería artesanal y la minería ilegal ejercen un rol importante.

Es así que los países latinoamericanos se asemejan más al Perú en cuanto a los problemas sociales y ambientales que les genera la minería ilegal, además de que también son productores de minerales importantes; como por ejemplo: México, Argentina, Chile, Bolivia, Ecuador y Colombia. Es por ello, que la comparación entre legislaciones se va a centrar en estos últimos casos.

En los casos de México, Argentina, Chile, Bolivia, Ecuador y Colombia cuentan con una legislación penal que incluye los delitos contra el medio ambiente y la minería ilegal; sin embargo, casi ningún país posee una legislación que establezca la diferencia entre la minería ilegal y la minería informal, ni leyes que fomenten la formalización de la minera, ni mucho menos un proceso de formalización con pautas y requisitos establecidos, como sí ocurre en la Legislación Peruana.

En primer lugar, México determina en el artículo 19 que la concesión minera concede el derecho a los titulares a explorar y explotar los minerales, así como a disponer de ellos; y en caso de desearlo, la posibilidad de trasmitir su titularidad a un tercero (Ley Minera , 1992). La entidad componente para otorgar la concesión minera es la Subsecretaría de Minería, que forma parte de la Secretaria de Economía.

Con respecto a combatir la minería ilegal, el (Código Penal Federal, 1931) incluye los delitos contra el ambiente, los cuales imponen penas a quienes produzcan daños a los minerales, a los ecosistemas, al suelo o subsuelo y a la calidad del agua, mediante el desarrollo de actividades de producción, como señala el artículo 414; sin embargo, no regula expresamente el delito contra la minería ilegal. Por ende, México tampoco cuenta con una regulación sobre la minería informal ni la formalización minera.

Como segundo caso, en Argentina el Código de Minería, la Ley $N^{\circ} 1919$, determina en los artículos 2 y 3 que las minas de oro, plata, cobre, etc., pueden ser explotadas si se le otorga una concesión minera a un particular; solo en ese caso se le puede considerar una actividad legal. 
A su vez, el Código Penal de la Nación Argentina regula en artículo 174 que sufrirá prisión de dos a seis años: "el que maliciosamente afectare el normal desenvolvimiento de un establecimiento o explotación" minera, entre otros (Ley $\mathrm{N}^{\mathrm{o}}$ 11.179, 1984). Sin embargo, al igual que México, Argentina no legisla la diferenciación entre la minería ilegal e informal, ni la formalización minera.

En tercer lugar, Bolivia sí posee una legislación expresa en contra de la explotación ilegal de los recursos minerales, tanto en las leyes mineras como en la penales. La Ley de Minería y Metalurgia regula en el artículo 104 que: "El que realizare actividades de explotación de recursos minerales, sin contar con la autorización o derecho otorgado en el marco de la presente Ley, incurre en explotación ilegal" (Ley № 535 , 2014); ante lo cual, se deberán detener las actividades ilegales y comunicar al Ministerio Público.

Por otro lado, la Ley № 367 incorporó en el Código Penal Boliviano los delitos de avasallar un área minera, venta o compra ilegal de recursos minerales y en el artículo 232 señala: "El que realizare actividades de explotación de recursos minerales sin contar con autorización o derecho otorgado en el marco de la normativa vigente, será sancionado con privación de libertad de cuatro (4) a ocho (8) años" (Decreto Ley No 10.426, 1972).

En cuarto lugar, Chile determina en el primer artículo de su Código Minería que el derecho para la exploración y explotación de los minerales solo se obtiene a través de la obtención de una concesión minera, siendo la entidad competente para otorgarla el Ministerio de Minería.

En el año 2003 el Gobierno de Chile expidió el Decreto $N^{\circ} 76$ que aprobó la Política de la Pequeña y Mediana Minería con el objetivo de fomentar el correcto desenvolvimiento de dichas actividades mineras: facilitando financiamiento de parte del Estado, capacitaciones para los mineros y acceso a mercados internacionales. Sin embargo, Chile no posee una legislación que condene la minería ilegal, por más que en la práctica sí sufre sus efectos, aunque en una magnitud mucho menor en comparación con los demás países de Sudamérica. 
En materia ambiental, se incluye que los proyectos mineros, al ser susceptibles de producir daños al medio ambiente, están obligados a obtener una EIA; sin embargo, lo menciona solo en el artículo 10 y junto a otras actividades económicas (Ley $\mathrm{N}^{\mathrm{o}}$ 19.300, 1994).

En quinto lugar, Ecuador si bien no posee aún una legislación sobre la formalización minera como un proceso en sí, sus funcionarios y entidades públicas han expresado en numerosas ocasiones la diferencia entre la minería ilegal e informal, la necesidad de fomentar que toda actividad minera que se desarrolle en el país cumpla con los parámetros mineros y ambientales; y la urgencia de legislar la formalización minera para contrarrestar así los daños que genera la actividad minera no legal.

El artículo 31 la Ley De Minera determina que el Estado de Ecuador otorga concesiones a favor de los particulares, y que el título minero "confiere a su titular el derecho exclusivo a prospectar, explorar, explotar, beneficiar, fundir, refinar, comercializar y enajenar todas las sustancias minerales que puedan existir y obtenerse en el área de dicha concesión" (Ley $\left.N^{\circ} 45,2009\right)$. Es decir, que para la explotación minera se necesita de una concesión minera.

A su vez, en el artículo 57 regula las sanciones de la minería ilegal desde una perspectiva administrativa y determina que será sancionada "sin perjuicio de las aplicables en los ámbitos ambiental, tributario o penal, a las que hubiere lugar", además de decomisos y destrucciones de maquinarias e insumos que se utilicen para la minería ilegal (Ley $\mathrm{N}^{\circ} 45,2009$ ).

En cuanto a los delitos, el (Código Orgánico Integral Penal, 2014) en el artículo 260 regula lo siguiente:

La persona que sin autorización de la autoridad competente, extraiga, explote, explore, aproveche, transforme, transporte, comercialice o almacene recursos mineros, será sancionada con pena privativa de libertad de cinco a siete años. 
En caso de minería artesanal será sancionada con pena privativa de libertad de uno a tres años. Si producto de este ilícito se ocasionan daños al ambiente, será sancionada con pena privativa de libertad de siete a diez años.

Los funcionarios del Ministerio de Minería de Ecuador se han reunido con representantes de los mineros artesanales para escuchar sus necesidades y regular la formalización minera de la mejor manera posible; así como también han aceptado consejos de países con legislación más avanzada sobre el tema, entre los que se encuentra el Perú (Ministerio de Minería iniciará proceso de formalización a mineros artesanales, 2018) ${ }^{12}$. En febrero del presente año, anunciaron que se dará inicio a un proceso de formalización minera de una manera compleja, que abarque temas mineros, ambientales y sociales.

Por último, de todos los casos mencionados anteriormente, Colombia es el país de Sudamérica que cuenta con la mejor legislación minera en lo que respecta a la actividad formal e informal; sobre la formalización minera incluye los requisitos, entidades competentes y plazos a seguir. Si bien no llega al nivel de complejidad con el que el Perú supervisa esta actividad, si está varios pasos por delante de los demás países de la región.

El Código de Minas de Colombia determina en el artículo 14 que: "Únicamente se podrá constituir, declarar y probar el derecho a explorar y explotar minas de propiedad estatal, mediante el contrato de concesión minera, debidamente otorgado e inscrito en el Registro Minero Nacional". Dicho contrato podrá durar hasta treinta años como máximo, ante lo cual el titular podrá solicitar luego una prórroga por el mismo plazo (Ley Nº 685 , 2001).

En el año 2010, la Ley N 1382, que modificó el Código de Minas, reguló la legalización minera en el artículo 12:

\footnotetext{
${ }^{12}$ Recuperado de la página web de EcuadorInmediato, el Periódico instantáneo del Ecuador.
} 
Los explotadores, los grupos y asociaciones de minería tradicional que exploten minas de propiedad estatal sin titulo inscrito en el Registro Minero Nacional, deberán solicitar, en el termino improrrogable de dos (2) años contados a partir de la promulgación de la presente ley, que la mina o minas correspondientes le sean otorgadas en concesión llenando para el efecto todos los requisitos de fondo y de forma (Ley $\left.\mathrm{N}^{\circ} 1382,2010\right)$.

En materia penal, Ley $\mathrm{N}^{\circ} 599$ de 2000, es decir, el Código Penal Colombiano, regula los delitos con respecto al daño que se ocasionan a los recursos minerales o al medio ambiente.

De manera general, el Código Penal regula en el artículo 331 los daños a los recursos naturales con su agravante, es decir, que se vean afectados los ecosistemas protegidos; en el artículo 332, podemos encontrar el delito de contaminación ambiental hacia el aire, atmósfera, suelo, subsuelo y aguas; y en el artículo 332A, el delito de la contaminación ambiental causada por residuos sólidos peligrosos (Ley Nº 599, 2000).

El artículo 333 del Código Penal Colombiano regula la contaminación ambiental como causa de la explotación de yacimientos mineros, y señala que la persona que contamine o afecte los recursos naturales caerá en prisión de cinco a diez años más las respectivas multas.

El artículo 338 del Código Penal Colombiano determina lo siguiente:

El que sin permiso de autoridad competente o con incumplimiento de la normatividad existente explote, explore o extraiga yacimiento minero, o explote arena, material pétreo o de arrastre de los cauces y orillas de los ríos por medios capaces de causar graves daños a los recursos naturales o al medio ambiente, incurrirá en prisión de treinta y dos (32) a ciento cuarenta y cuatro (144) meses y multa de ciento treinta y tres punto treinta y tres (133.33) a cincuenta mil (50.000) salarios mínimos legales mensuales vigentes.

(Ley No 599, 2000). 
Colombia cuenta con una legislación sobre la formalización minera que evolucionó con el tiempo, al igual que la legislación Peruana. El Ministerio de Minas y Energía se divide en el Viceministerio de Minas y en el Viceministerio de Energía; el primero, a su vez, se divide en dos: en la Dirección de Minería Empresarial, que determina las políticas para las actividades mineras en concordancia con la normativa existente, y en la Dirección de Formalización Minera, que se va a explicar a continuación.

Las funciones de la anterior entidad mencionada se encuentran mencionadas en el artículo 13, algunas de las cuales son las siguientes:

- Planificar los reglamentos técnicos de las actividades conectadas con la formalización minera.

- Formulación de políticas para legalizar y desarrollar la minería tradicional.

- Arreglar con los demás Ministerios y entidades del Estado la disolución de los problemas de la formalización minera.

(Decreto $N^{\circ} 381,2012$ )

La Ley $N^{\circ} 1658$ del 15 de julio de 2013 dispuso regulaciones para reducir y acabar con el uso del mercurio en las actividades industriales, incluyendo en ellas a la minería; además, determinó por primera vez los instrumentos creados para promover la formalización minera: el subcontrato de Formalización Minera, la devolución de áreas y más beneficios.

En junio de 2015 se expidió el Plan Nacional de Desarrollo de Colombia, dónde el artículo 19 determinó que el Subcontrato de Formalización Minera es un mecanismo para explotar como pequeña minería; ante lo cual, luego de la aprobación del contrato se deberá inscribir en el Registro Minero Nacional (Ley No 1753, 2015).

De igual manera, el artículo 21 de la Ley $\mathrm{N}^{\circ} 1753$, ordena las clasificaciones de las actividades mineras, las cuales son las siguientes: la minería de subsistencia, la pequeña, la mediana y la gran minería. En el caso de Colombia, la formalización minera es aplicable a la pequeña minería; en cambio, en el Perú se aplica también a la artesanal. 
Por último, el 26 de mayo de 2015 se expidió el Decreto № 1073, más adelante modificado y complementado por el Decreto No 1949 del 28 de Noviembre de 2017; fue la primera norma jurídica que enfocó la Formalización Minera como un proceso con pasos, requisitos y parámetros ambientales que cumplir, además de la respectiva fiscalización para cada caso.

La primera sección del Decreto $\mathrm{N}^{\mathrm{o}} 1073$ abarca los aspectos técnicos $\mathrm{y}$ ambientales, como actuar en las áreas con títulos mineros o las zonas restringidas y las causales de rechazo. La segunda sección, modificada por el Decreto № 1949 de 2017 , incluye lo referente al contrato de Formalización Minera, como por ejemplo: su ámbito de aplicación, el contenido que debe incluir, la autorización ante la Autoridad Minera Nacional, la evaluación, aprobación, prórroga y causales que concluirían el subcontrato de Formalización Minera (Decreto $\left.\mathrm{N}^{\circ} 1073,2015\right)$.

La tercera sección del Decreto No 1073, incluida por el Decreto № 1949 de 2017, regula la devolución de áreas, la cual según el artículo 2.2.5.4.3.1. es: "La realizada por el titular minero como resultado de un proceso de mediación o por decisión directa de este, con el fin de contribuir a la formalización de la pequeña minería”. Y por último, para concluir con la formalización minera, se necesitan aplicar las guías ambientales y obtener la licencia ambiental respectiva (Decreto $\mathrm{N}^{\circ} 1073,2015$ ).

A manera de resumen, por más que los países mencionados sufren los efectos generados por la explotación de los recursos mineros fuera de los alcances de las obligaciones legales mineras y ambientales - los cuales afectan negativamente al medio ambiente, la recaudación tributaria de los Estados y la calidad de vida de la poblaciónno cuentan con una legislación minera que aclare la diferencia entre la minería ilegal y la informal; y por ende, tampoco tienen un proceso de formalización minera.

Si bien en materia penal sí regulan los delitos relacionados con la minería ilegal, al no permitir que las personas que incurren en dichas actividades puedan regularse e integrarse progresivamente para actuar conforme a ley, no se solucionará el problema de raíz, que a largo plazo, es la mejor opción. Por ende, es necesario que se regule la minera informal para diferenciarla de la minería ilegal; y que cada país establezca los pasos y 
requisitos hacia la formalización que considere necesarios y prácticos de acuerdo a sus respectivas realidades.

En el caso de Ecuador, las autoridades mineras tienen claro que la formalización minera es la meta a la cual deben aspirar para que los mineros artesanales - quiénes son los sujetos más propensos a incumplir la ley por la falta de oportunidades para satisfacer sus necesidades - puedan mejorar sus condiciones laborales, de salud, seguridad, así como para que disminuyan los efectos negativos al medio ambiente y a la recaudación tributaria del Estado. Y como han expresado, planean instaurar este cambio en la menor brevedad posible.

Colombia por su caso es el país de la región, a excepción de Perú, que cuenta con la legislación más avanzada en cuando a la formalización minera, debido a que lo enfoca como un proceso y además regula las diferencias entre la minería ilegal e informal, el contenido de los contratos entre los mineros que explotan los minerales y concesionarios mineros, los plazos, los requisitos y las obligaciones ambientales a cumplir; sin dejar de lado que crearon una Dirección especial inscrita al MINEM para que actúe de entidad competente.

La región más afectada por la minería ilegal en toda la Amazonía Sudamericana es Madre de Dios en Perú, y en Colombia dicha actividad se relaciona con el desarrollo del Narcotráfico, actividades que se apoyan y dificultan la reacción de las autoridades para combatirlas.

Ante estas dos realidades, es comprensible que ante la necesidad de frenar los daños generados por la explotación de minerales fuera de los alcances de la ley, los Estados de Perú y Colombia fueron los primeros en regular la formalización minera; aunque en un inicio los procesos tuvieran errores y se hayan ido perfeccionando con el paso del tiempo y sigan siendo aún susceptibles de modificaciones en un futuro.

A manera de conclusión, la legislación comparada dista mucho de la legislación minera que existe en el Perú, de manera general y de manera específica en lo que respecta a la formalización de la minería, la cual comenzó a regularse en el año 2002 con la Ley 
No 27651 y en el año 2012, el Decreto Legislativo No 1105 creó el primer proceso, que marcaba los pasos a seguir de una manera más compleja y ordenada.

La legislación peruana minera es la más avanzada de la región debido a que regula con leyes especiales los diferentes aspectos de la actividad minera, como por ejemplo: el uso sostenible de los recursos naturales, los diversas concesiones mineras con sus derechos y obligaciones, el régimen general de minería, la artesanal y pequeña minería, los Instrumentos de Gestión Ambiental, la Salud y Seguridad en la minería, los procedimientos mineros, el uso de los recursos hídricos, el CIRA y la formalización minera, etc.; además de contar con reglamentos que complementan las leyes que regulan los temas mencionados.

Con respecto al PFMI en el Perú, esta abarca lo siguiente: las disimilitudes entre la minería ilegal e informal - siendo la última susceptible de formalizarse -, los requisitos a acreditar sobre el terreno superficial, la titularidad o contratos de explotación de la concesión y el certificado de protección del medio ambiente; así como también: plazos, causales de extinción, entidades competentes - muchas de las cuales fueron creadas con ese objetivo - y los requisitos para inscribirse en el registro competente, el cual los acredita como mineros formales.

Además, en el ámbito penal, la mayoría de países de la región regulan los delitos contra el medio ambiente de manera general y en algunos casos ni cuentan con el delito de minería ilegal; en cambio, Perú regula los delitos de contaminación al medio ambiente, vertimiento y tráfico de residuos peligrosos, depredación de flora y fauna y la minería ilegal; además de otros delitos relacionados con el tema, como por ejemplo: el financiamiento, el tráfico de insumos y el uso de maquinarias para la minería ilegal. Por otro lado, de manera complementaria y necesaria a la regulación de estos delitos, el Estado Peruano creó Fiscalías y Juzgados Ambientales especializados para que actúen como entidades competentes en estos casos.

Por ende, si los países de Latinoamérica desean iniciar una lucha efectiva contra la minería ilegal, los temas que deberían legislar son: los delitos contra el medio ambiente, la diferencia entre la minería ilegal e informal, un proceso ordenado con pasos y plazos 
específicos para la formalización minera, fiscalización para los que logren formalizarse, capacitaciones para los funcionarios públicos y los mineros informales sobre la formalización, crear entidades administrativas especializadas para que sean competentes; y por último, aceptar que es un proceso en evolución que se puede modificar y mejorar si los resultados que se obtienen no son los deseados, siempre en beneficio de la realidad de cada país.

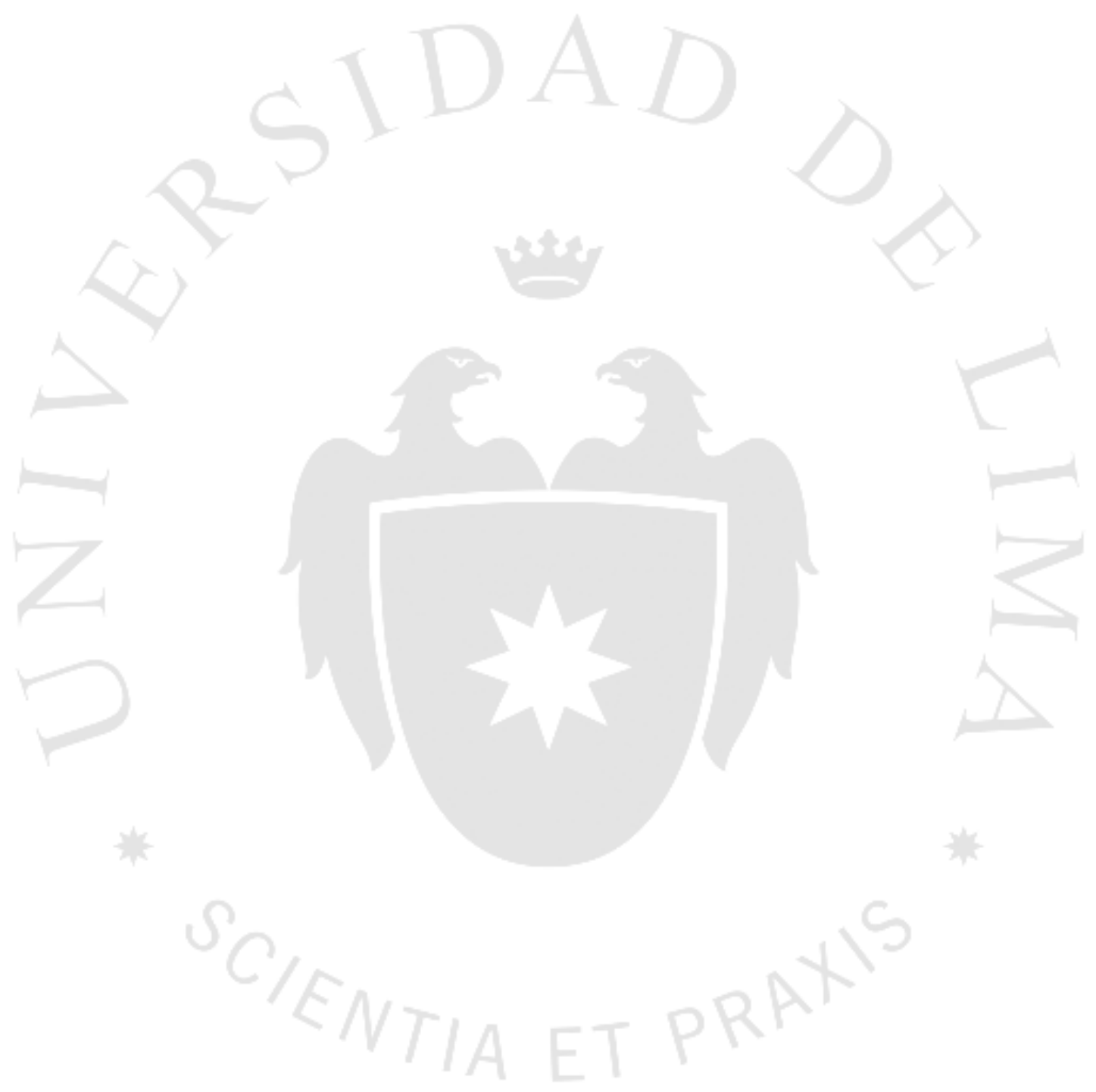




\section{CAPÍTULO V: LA VULNERACIÓN DE LOS DERECHOS DE LOS CONCESIONARIOS MINEROS}

\subsection{Análisis de cómo se desarrolla actividad minera en el régimen general en comparación con el Proceso de Formalización Minera Integral}

Para realizar una correcta comparación y un posterior análisis, primero serán expuestos brevemente los procedimientos administrativos necesarios para el ejercicio de actividad minera según las normas jurídicas de la materia, señalando las autoridades competentes y cómo se realizan dichos trámites, tanto para el régimen general como para el Proceso de Formalización Minera Integral, los mismos que de acreditar los requisitos obligatorios son declarados mineros formales.

Para realizar actividad minera se deben completar numerosos procesos administrativos y cumplir con los requisitos establecidos en el TUO de la LGM, su Reglamento y el de Procedimientos Mineros; siendo estos requisitos: la concesión minera, la propiedad o autorización de uso del terreno superficial, el IGA, el CIRA, el Derecho de uso de agua y la autorización para el inicio o reinicio de las actividades mineras.

En primer lugar, la concesión minera es el título habilitante que le permite al particular ejercer una actividad económica; existen diversos tipos: exploración, explotación, beneficio, labor general y transporte minero. Además, existen diferentes niveles de producción, como el régimen general, la pequeña minería y la minería artesanal.

La pequeña minería y la minería artesanal tienen su propia legislación especial con la Ley No 27651 y su Reglamento aprobado mediante D.S. No 013-2002-EM. Primero, los sujetos interesados deben acreditar la condición de Pequeño Productor Minero o la condición de Productor Minero Artesanal ante la DGM, siguiendo los 
requisitos del artículo 5 y el artículo 12, respectivamente, del Reglamento. Luego, los administrados podrán presentar ante el Gobierno Regional competente el petitorio de la concesión minera.

En el régimen general la autoridad competente es distinta, los administrados deben presentar "su petitorios de concesión minera ante cualquiera de las mesas de partes del Instituto Geológico, Minero y Metalúrgico - INGEMMET”, según el artículo 12 del Reglamento de Procedimientos Mineros.

Para el procedimiento ordinario de concesiones mineras, la autoridad competente ante la cual se debe presentar el petitorio es "cualquier Oficina del Registro Público de Minería, o la entidad que autorice dicho registro", según indica el artículo 118 del TUO de la LGM. Luego de las publicaciones respectivas, de no producirse oposición y producidos los dictámenes técnicos y legales favorables, el Jefe del Registro Público de Minería otorgará el título habilitante; a continuación, a solicitud del interesado se procede a la inscripción.

De acuerdo a lo que regula el artículo 129 del TUO de la LGM, la competencia para solicitar las concesiones de beneficio, labor general y transporte minero es de la Dirección General de Minería.

En segundo lugar, para desarrollar actividad minera legal se necesita la acreditación de propiedad o autorización de uso del terreno superficial; para ello, se debe presentar un documento que lo acredite por parte del cien porciento de las acciones y derechos del predio, según el artículo 35 del D.S. No 018-92-EM.

En tercer lugar, se encuentra el Instrumento de Gestión Ambiental, el cual se categoriza dependiendo el riesgo ambiental que genera un determinado proyecto. La Categoría I, la DIA, se requiere en los proyectos que no generan impactos negativos significativos; la Categoría II, el EIA-sd, engloba los que pueden generar impactos moderados; y la Categoría III, el EIA-d, incluye los que producen impactos ambientales negativos significativos. 
Respecto a quién es la autoridad competente para aprobar el IGA que corresponda, para la DIA es el Gobierno Regional competente, para el EIA-sd es el sector (MINEM) y para el EIA-d es el SENACE.

En cuarto lugar, para ejercer actividad minera legal se necesita del derecho de uso de agua, la autoridad competente para otorgarlo es la ANA, lo cual lleva a cabo mediante una resolución administrativa. Existen distintos derechos de uso de agua, el administrado determina cual es el que necesita de acuerdo a sus necesidades.

En quinto lugar, se necesita del CIRA, la autoridad competente ante la cual se debe presentar la solicitud es la Dirección de Certificaciones o la Dirección Desconcentrada de Cultura, según señala el artículo 55 del Decreto Supremo No 003 2014-MC.

Por último, todos los requisitos mencionados anteriormente no son suficientes para poder desarrollar actividad minera sino se obtiene la autorización para el inicio o reinicio de las actividades de exploración, desarrollo, preparación y explotación.

En contraste con lo desarrollado anteriormente sobre el régimen general, lo que viene a continuación es el proceso a seguir para lograr la inscripción en el REINFO, y posteriormente, los requisitos necesarios para finalizar correctamente la formalización Minera, lo cual también permite desarrollar actividad minera.

El primer paso es la inscripción en el REINFO, pueden formar parte: los mineros informales que contaban con una inscripción vigente en los registros anteriores, los titulares de concesiones mineras en áreas declaradas como zonas de exclusión minera y quiénes explotan minerales como pequeña minería y minería artesanal, siempre que estuvieran inscritas en la SUNAT, conforme regula el artículo 5 del D.S. No 018-2017EM.

La inscripción en el REINFO se realizó mediante la web de la SUNAT, en la sección “operaciones en línea”. No obstante, la entidad competente para administrar, 
fiscalizar y modificar el REINFO es la Dirección General de Formalización Minera del MINEM.

El siguiente paso es completar todos los requisitos del proceso de formalización señalados en el artículo 3 del D.L. No 1336 , proceso que tiene una vigencia de treinta y seis (36) meses ${ }^{13}$, para así lograr la declaración de minero formal.

Ante eso, el primero de los requisitos es la aprobación del IGAFOM o del IGAC, estas medidas son necesarias para la prevención, manejo y arreglo de los impactos negativos sobre el medio ambiente al realizar actividad minera de explotación.

La autoridad competente para evaluar y aprobar el IGAFOM es la Dirección Regional de Energía y Minas competente. Luego de la evaluación, la autoridad competente emite el acto administrativo que aprueba o desaprueba dicho instrumento, conforme señalan los artículos 4 y 13 del D.S. № 038-2017-EM. En el caso del IGAC, la autoridad competente para su trámite y aprobación es el Gobierno Regional competente.

El segundo requisito es la Acreditación de Titularidad, Contrato de Cesión o de Explotación sobre la concesión minera; de ser titular, dependiendo del caso, se debe indicar el número de la partida registral y Oficina Registral de la SUNARP, según el artículo 20 del D.S. No 018-2017-EM.

El tercer requisito es la Acreditación de Propiedad o Autorización de Uso del Terreno Superficial, se presenta ante el Gobierno Regional competente y el minero informal debe probar lo siguiente: qué es el propietario, qué está autorizado por él o los propietarios o indicar que se encuentra sobre terreno eriazo del estado, de acuerdo al artículo 11 Decreto Legislativo $\mathrm{N}^{\circ} 1336$.

\footnotetext{
${ }^{13}$ Los treinta seis meses se cuentan desde de la culminación del plazo de inscripción, el cual abarcó del 6 de febrero de 2017 al 1 de agosto del 2017.
} 
El cuarto y último requisito necesario para culminar el PFMI es la autorización de inicio o reinicio de las actividades mineras, la cual la emite la Dirección y/o Gerencia Regional de Energía y Minas. Es importante resaltar que el minero sujeto al proceso de formalización no esta obligado a esperar culminarlo para iniciar sus actividades, sino que puede hacerlo desde el momento que presentó su declaración de compromiso o se inscribió en el REINFO, según sea el caso. Ello a diferencia que los mineros sujetos al régimen general, que deberán esperar a tener todos los requisitos exigibles para iniciar sus actividades.

La autoridad competente debe verificar que los mineros informales hayan acreditado los tres requisitos mencionados previamente, además de cumplir con presentar la Declaración Jurada de Inexistencia de Restos Arqueológicos y un expediente técnico. Con la emisión de dicha autorización culmina la formalización minera y se declara la condición de minero formal.

Tabla 5.1

Requisitos para desarrollar actividad minera

\begin{tabular}{|c|c|}
\hline Régimen General & Proceso de Formalización Minera Integral \\
\hline La concesión minera & $\begin{array}{c}\text { Acreditación de Titularidad, Contrato de } \\
\text { Cesión o Contrato de Explotación respecto de la } \\
\text { concesión minera }\end{array}$ \\
\hline \multicolumn{2}{|c|}{ Acreditación de propiedad o autorización de uso del terreno superficial } \\
\hline $\begin{array}{l}\text { Instrumento de Gestión Ambiental: DIA, } \\
\text { EIA-sd o EIA-d }\end{array}$ & $\begin{array}{l}\text { Instrumento de Gestión Ambiental: IGAFOM } \\
\text { IGAC }\end{array}$ \\
\hline $\begin{array}{c}\text { Autorización para el inicio/reinicio de las } \\
\text { actividades de exploración, desarrollo, preparación } \\
\text { y explotación }\end{array}$ & \multirow{4}{*}{$\begin{array}{c}\text { Autorización de inicio/reinicio de actividades } \\
\text { mineras de explotación y/o beneficio de minerales } \\
\text { y/o título de concesión de beneficio }\end{array}$} \\
\hline Certificación de Inexistencia de Restos & \\
\hline Arqueológicos & \\
\hline to de uso de agua & \\
\hline
\end{tabular}

Fuente: Fuente: D. L. N 1336, D. S. Nº 014-92-EM y D. S. No 018-92-EM. Elaboración propia.

Como se puede apreciar con el presente análisis, el camino a seguir para un sujeto de derecho que desea realizar actividad minera de explotación, cumplimiento con todas las obligaciones legales, es de mayor complejidad y dificultad dentro del régimen general en comparación con el Proceso de Formalización Minera Integral. 
En lo referente a los organismos e instituciones públicas, los sujetos interesados deben completar procedimientos administrativos ante un mayor número de entidades dentro del régimen general para realizar actividad minera, algunos ejemplos son: el SENACE, la Dirección Desconcentrada de Cultura, la ANA, la Dirección General de Minería, INGEMMET o los Gobiernos Regionales. En cambio, debido a la exigencia de un menor número de requisitos y con la simplificación de otros, para la formalización minera se siguen procedimientos administrativos ante menos entidades, como la Dirección General de Formalización Minera del MINEM o la Dirección Regional de Energía y Minas correspondiente, ante la cual se acreditan varios requisitos.

Por otro lado, las personas naturales o jurídicas que realizan actividad minera deben cumplir con las obligaciones establecidas en el TUO de la LGM, como el pago del derecho de vigencia, la producción o inversión mínima, el pago de penalidades, cumplir con las normas de seguridad e higiene, la presentación de la Declaración Anual Consolidada, ser objetos de una fiscalización continua, entre otros. Los mineros informales pactan con estos titulares mineros durante el PFMI, deben cumplir con menos obligaciones y consiguen la formalización; muchas veces sin encontrarse preparados para hacerse cargo de estas actividades a largo plazo.

Dentro del régimen general normalmente los titulares necesitan obtener varias concesiones mineras para poder realizar actividad minera debido a qué abarcan todos los aspectos de esta compleja actividad; en cambio, las normas del Proceso de Formalización Minera Integral solo exigen la inscripción en el REINFO y acreditar, no obligatoriamente antes de empezar la actividad de explotación, la titularidad o un contrato de cesión o de explotación respecto de la concesión minera; lo cual no es garantía de que el minero informal vaya a concluir el proceso de formalización.

El contrato de cesión minera y el contrato de explotación minera se pueden suscribir tanto en el ámbito del régimen general como en el PFMI, la diferencia radica en que fuera del proceso el tercero no posee ningún derecho ni la facultad para realizar actividad minera alguna hasta que se suscriban los contratos mineros; en cambio, dentro del proceso mencionado, por más que todavía el minero informal no haya cumplido con 
acreditar dicho requisito, mientras cuente con la inscripción vigente en el REINFO posee la facultad para explotar los recursos minerales.

El PFMI simplifica en extremo un proceso normalmente largo y complejo, esta simplificación ocurrió a través de los años, desde el Decreto Legislativo $N^{\circ} 1105$ que incluía como requisitos la autorización de uso de aguas y el certificado de inexistencia de restos arqueológicos, hasta el vigente Decreto Legislativo $\mathrm{N}^{\circ} 1336$ donde solo se deben acreditar el Instrumento de Gestión Ambiental, la propiedad o autorización del terreno superficial, la titularidad o contrato de cesión o explotación sobre la concesión minera y la autorización de inicio o reinicio de actividades mineras de explotación o beneficio.

La simplificación tanto para la inscripción en el REINFO como para la acreditación de los requisitos, permite que muchos mineros informales se encuentran en la posición de perjudicar los derechos adquiridos por los concesionarios mineros, al aprovecharse de las facultades que les otorga la formalización y actuar de mala fe.

\subsection{Análisis sobre el Proceso de Formalización Minera Integral y la vulneración que permite sobre los derechos de los concesionarios mineros}

Luego de exponer y analizar la normativa vigente del proceso de formalización, además de sus antecedentes y su continua influencia, se afirma la hipótesis principal del presente trabajo de investigación: el PFMI permite que los mineros informales que no han acreditado los requisitos necesarios para culminarlo, tengan la posibilidad durante la vigencia del mismo, de explotar y comercializar recursos minerales sobre los que no poseen ningún derecho, vulnerando de esa manera los derechos de los titulares de las concesiones mineras.

El Proceso de Formalización Minera Integral puede abarcar diferentes situaciones: el desarrollo de actividad minera de explotación dentro del área de una concesión o dentro de un terreno eriazo del Estado. Específicamente, la hipótesis de este trabajo de investigación se centra en el primer supuesto, cuando el minero informal no es el titular de la concesión minera ni ha suscrito un contrato de cesión o contrato de 
explotación minera con el titular; de esta manera, el concesionario minero se encuentra en una posición de desventaja.

El artículo 2 y el artículo 70 de la Constitución Política del Perú de 1993 comprenden el derecho a la propiedad, ante lo cual, el Estado Peruano es el encargado de garantizar que sea respetado. Los titulares de las concesiones mineras lo pueden ver vulnerado como consecuencia del desarrollo del PFMI por parte de los mineros informales.

El artículo 10 del TUO de la LGM regula que: "La concesión minera le otorga a su titular un derecho real”, el cual le otorga el poder jurídico inmediato y absoluto para usar, disfrutar, disponer y reivindicar sobre el bien inmueble; además, ese derecho excluye a terceras personas de la posibilidad de hacer lo mismo, siendo así los mineros ilegales e informales los que no respetan el derecho de propiedad del concesionario minero en el caso de una invasión minera.

Por otro lado, el PFMI acepta que los mineros informales exploten los recursos minerales sin ser los titulares de la concesión minera dónde se encuentran, o sin haber suscrito un contrato minero con los respectivos titulares; cabe recordar que estos últimos son los legítimos propietarios de los minerales explotados; de esa manera se vulnera el derecho de propiedad de los concesionarios por parte de los mineros informales inscritos en el REINFO.

Además, como ocurre en el caso práctico que se desarrolla en el Anexo I, los mineros informales pueden invadir la concesiones mineras en contra de la voluntad de sus titulares y amenazar con la intención de continuar con dichas prácticas, para de esa manera, intentar forzar a los concesionarios mineros a pactar con ellos y continuar así con el proceso de formalización.

En segundo lugar, otro derecho fundamental que se puede ver afectado con el Proceso de Formalización Minera Integral es al debido proceso, regulado en el inciso 3 del artículo 2 y en el inciso 3 del artículo 139 de la Constitución Política. 
El Tribunal Constitucional en la (STC 04944-2011-PA/TC, 2012) establece lo siguiente sobre el debido proceso:

Es aplicable no solo a nivel judicial sino también en sede administrativa e incluso entre particulares. Supone el cumplimiento de todas las garantías, requisitos y normas de orden público que deben observarse en las instancias procesales de todos los procedimientos, incluidos los administrativos y conflictos entre privados, a fin de que las personas estén en condiciones de defender adecuadamente sus derechos ante cualquier acto que pueda afectarlos.

El Estado, a través de las entidades competentes en materia de minería, tiene la intención de promover la formalización minera, y lo ha demostrado en numerosas ocasiones con la simplificación y la eliminación de requisitos, así como con las constantes nuevas oportunidades que le otorgan a los mineros informales al fallar en sus intentos de culminar con los procesos de formalización minera.

En los casos como el que se expone en el Anexo I, las autoridades competentes pueden tomar conocimiento de los conflictos que surgen entre los mineros informales y los titulares mineros pero no intervienen ni excluyen a los mineros informales del REINFO, debido a que su prioridad es hacer todo lo posible para salvaguardar el desarrollo del proceso de formalización, cayendo así en actuaciones arbitrarias, sobre todo si es notorio que los derechos de los concesionarios mineros no están siendo respetados.

En tercer lugar, la Constitución Política (1993) en el artículo 59 regula: "El Estado estimula la creación de riqueza y garantiza la libertad de trabajo y la libertad de empresa, comercio e industria", y en el artículo 61 que "El Estado facilita y vigila la libre competencia".

El objeto social de las empresas mineras es la explotación minera y la posterior comercialización de los recursos minerales extraídos, actividades que se ven afectadas por el mal uso del proceso de formalización por parte de los mineros informales; ante eso, se generan pérdidas económicas tanto porque los concesionarios mineros no pueden explotar directamente los minerales como porque los explotan los minero informales y 
no les pagan una contraprestación por ello, además, imposibilita a los titulares mineros de competir libremente con otros agentes económicos.

Por último, el inciso 15 del artículo 2 de la Constitución Política de 1993 regula el derecho a trabajar libremente; y el inciso 14, el derecho a contratar con fines lícitos. El proceso de formalización permite que los mineros informales se encuentren en la posición ideal para imposibilitar a los concesionarios mineros a trabajar libremente, si admite el inicio de dicho proceso en las áreas de sus concesiones mineras sin haber contado previamente con su participación; los titulares ya no serían los únicos sujetos con la intención de realizar explotación minera en el área determinada, ante lo cual surgen los conflictos.

Además, los titulares mineros poseen la facultad de contratar y de suscribir contratos de cesión o explotación minera con las personas de su preferencia; sin embargo, los titulares no cuentan con las herramientas necesarias para evitar las invasiones mineras ni para rechazar el Proceso de Formalización Minera Integral desde un inicio, ante su negativa a pactar con los mineros informales. Lo anteriormente mencionado ocurre debido a la falta de presencia del Estado y su falta de reacción ante los problemas que se generan.

La inscripción en el REINFO permite a los mineros informales desarrollar actividad minera, quiénes se "comprometen a presentar los requisitos exigidos para la culminación del Proceso de Formalización Minera Integral" conforme el artículo 7 del D.S. $N^{\circ}$ 018-2017-EM; sin embargo, no se toma en cuenta la voluntad de los concesionarios mineros. Se puede dar el caso en que estos últimos aún no han manifestado su decisión de pactar con los mineros informales, así como tampoco es su intención de hacerlo en un futuro, eligiendo válidamente explotar los minerales de su concesión minera de manera directa.

El artículo 7 del D.S. No $018-2017-E M$ determina las consecuencias de la inscripción en el REINFO, los mineros informales deben: "Desarrollar actividad minera respetando los compromisos asumidos y los requisitos por los cuales fueron inscritos en 
el Registro", además de la obligación de presentar todos los requisitos que señala el D.L. $\mathrm{N}^{\mathrm{o}} 1336$ para culminar el PFMI.

La inscripción en el REINFO no significó un procedimiento de mayor complejidad para los mineros informales, en comparación con la facultad que otorga de realizar actividad minera de explotación.

En el caso de los mineros informales que se incorporaron por contar con una inscripción vigente en los registros anteriores, al ocurrir de manera automática no se verificó el estado en que se encuentran respecto al cumplimiento de los requisitos, y se les otorgó una segunda o tercera oportunidad sin analizar la razón por la cual no pudieron formalizarse en el plazo que les correspondía. Por otro lado, la inscripción ante la SUNAT la llevaron a cabo vía el portal web de la SUNAT, contando solo con una inscripción vigente en el RUC y si cumplían con desarrollar actividad minera a título personal en una única concesión minera.

Los requisitos anteriormente mencionados necesarios para la inscripción en el REINFO son menos rigurosos en comparación con los necesarios para completar el PFMI, y aún menos en relación a los solicitados en el régimen general; sin embargo, otorgan la misma facultad de realizar actividad minera de explotación.

La protección que le ofrece la formalización minera a los mineros informales durante su plazo de vigencia, permite que se encuentren en una situación ideal para actuar en contra de los concesionarios mineros si así lo desean, pueden explotar los recursos minerales en su propio beneficio, los cuales una vez que han sido extraídos del subsuelo, son propiedad del titular minero.

Luego de finalizado el plazo de inscripción - que abarcó del seis de febrero al primero de agosto de 2017- corre el plazo de vigencia de treinta y seis meses del PFMI, según el artículo 6 del D.L. No 1293. Los requisitos necesarios para culminar el proceso se pueden acreditar en cualquier momento dentro de la vigencia indicada; así como tampoco se deben presentar en un orden establecido, es decir, se encuentran en un mismo 
nivel de importancia. Es más, el numeral 3.4 del artículo 3 del D.L. № 1336 señala que los requisitos "pueden ser tramitados o acreditados de manera simultánea".

Tres años es un plazo coherente para acreditar los requisitos legales; sin embargo, en los casos dónde los titulares mineros no tienen la intención de pactar con los mineros informales ni en el presente ni en el futuro, no contar con la oportunidad para manifestar esa decisión desde el inicio e interrumpir así el desarrollo del Proceso de Formalización Minera Integral, es perjudicial para los titulares.

Por otro lado, como se expuso en la primera parte del presente capítulo, el número de requisitos que exigen las normas vigentes se han reducido en comparación con el primer proceso de formalización minera: ya no se debe presentar la autorización de uso de aguas ni el CIRA; además de eso, se simplificaron los requisitos restantes.

La normativa vigente no considera oportuno exigir que se acrediten los requisitos con la mayor brevedad posible, o crear pasos específicos con plazos más pequeños; a pesar de tener en cuenta que son varios los requisitos, los mineros informales no avanzan con los trámites desde un inicio y corren con ellos el riesgo de que el plazo de vigencia para el PFMI llegue a su fin sin haber alcanzado los objetivos. Ante esto, los mineros informales no sienten presión de actuar rápido y son conscientes de que en el peor de los casos de concluir el plazo de vigencia, lo más probable es que el Estado lo amplíe o cree otro y les otorgue una nueva oportunidad.

El Estado Peruano viene realizando la práctica ya considerada común de ampliar los plazos establecidos para la formalización minera, modificar las leyes referentes al tema y crear nuevos registros para la inscripción de los mineros informales, lo cual se detallará a continuación.

Para el proceso de formalización del D.L. Nº 1105 se estableció el plazo de sesenta días calendario para presentar la Declaración de Compromisos ante el Gobierno Regional competente, lo cual daba inicio al proceso y a su respectiva inscripción. El artículo 3 del D.L. $\mathrm{N}^{\mathrm{o}} 1105$ estableció un plazo de vigencia máximo de veinticuatro meses, es decir, hasta el diecinueve de abril de 2014. Meses después, el cinco de setiembre de 2012 se 
publicó la Ley No 29910 y mediante un único artículo, creó un nuevo plazo de sesenta días hábiles para presentar la Declaración de Compromisos.

Años después, el Estado Peruano consideró que era necesario fortalecer, fiscalizar y ampliar la vigencia de dicho proceso de formalización, razón por la cual se aprobó mediante el Decreto Supremo No 029-2014-PCM la Estrategia de Saneamiento de la Pequeña Minería y de la Minería Artesanal.

Pudieron integrarse al Registro de Saneamiento los mineros informales que contaban con el estatus de vigente en el registro anterior, y que además cumplieran con tener un RUC a cargo de la SUNAT; esta vez, la Estrategia de Saneamiento tenía como objetivo el año 2016 para la formalización de la minería ilegal.

Dos años después, mediante el D.L. N 1293, se declaró de interés nacional la reestructuración del proceso de formalización, lo cual derivó en la creación del Proceso de Formalización Minera Integral; con su única disposición complementaria transitoria se prorrogó la vigencia de la Estrategia de Saneamiento hasta el primero de agosto de 2017; la misma fecha que significó el final del plazo de inscripción del nuevo proceso ante el REINFO.

El Proceso de Formalización Minera Integral es el último de los procesos mencionados y el que aún se encuentra vigente; según el artículo 6 del D.L. No 1293 cuenta con una vigencia de treinta y seis meses, plazo que corre desde el primero de agosto de 2017, es decir, se encuentra vigente hasta agosto del 2020, a menos que el Estado decida ampliar el plazo de vigencia.

En síntesis de los expuesto anteriormente, a lo largo de la evolución del proceso de formalización minera se fueron simplificando los requisitos obligatorios, se ampliaron y crearon nuevos plazos para culminar la formalización, y se permitió la incorporación de los mineros informales inscritos en los registros anteriores en el actual REINFO.

Ante el último caso, en el REINFO se pueden encontrar sujetos que comenzaron el primer proceso de formalización, es decir, mineros informales que iniciaron el proceso 
de formalización en el año 2012 y que ahora cuentan con plazo hasta el año 2020 para culminarlo; otorgándoles así un total aproximado de ocho años cuándo la intención del primer proceso regulado por el D.L. № 1105 fue de dos años. Además, en esos casos los mineros informales también se vieron beneficiados por la simplificación y la reducción de requisitos, ya que solo deben cumplir con la normativa actual.

Otorgar diversas oportunidades a los mineros informales para que se formalicen genera que no dirijan todos sus esfuerzos a acreditar los requisitos obligatorios en la mayor brevedad posible, lo cual muchas veces culmina en que no les alcanza el plazo establecido, y el Estado al ver que el proceso de formalización minera no genera los resultados deseados se ve obligado a ampliar los plazos.

Otra oportunidad que genera el PFMI en los mineros informales es la siguiente: conocer la negativa de los concesionarios mineros de pactar con ellos o ante la imposibilidad de acreditar alguno de los otros requisitos, aprovechan para explotar y comercializar recursos minerales durante la vigencia de dicho proceso, porque son conscientes de que no serán capaces de concluirlo satisfactoriamente.

Con esto, no se cumple con ninguno de los objetivos: no se aplican las medidas de materia penal, civil o administrativo a los mineros informales que siguen sin realizar actividad minera conforme a las leyes, como tampoco se logra que consigan la formalización definitiva. El Estado Peruano se percibe como una entidad débil, sin la fuerza necesaria para formalizar la actividad minera ni para combatir la ilegal; lamentablemente las acciones realizadas tanto por el Ministerio Público como el Poder Judicial ante los delitos de minería ilegal, por medio de las Fiscalías y los Juzgados Ambientales, no han generado hasta el momento resultados positivos.

Debido a todo lo mencionado, mientras esté vigente la formalización minera como está regulada en la actualidad, los titulares de las concesiones mineras se encontrarán en una posición vulnerable frente a los mineros informales. Al ampliarse los plazos de vigencia se continúa permitiendo la explotación minera no legal por parte de los mineros informales al no contar con permiso de los titulares de las concesiones mineras, con lo 
cual pueden vulnerar los derechos de los últimos si explotan los recursos minerales en su propio beneficio.

Desde la posición de un titular minero, no es lo mismo permitir el desarrollo del proceso de formalización en terreno de tu concesión por un plazo inicial de dos años, que de un proceso con una duración de ocho años; bajo la posibilidad de que se vuelva a ampliar el plazo debido a qué depende de la voluntad y las necesidades del Estado.

Además de lo mencionado, los mineros informales pueden utilizar el Proceso de Formalización Minera Integral para presionar a los titulares mineros a pactar con ellos, sobre todo teniendo en cuenta qué la intención de las entidades del Estado es promover la formalización minera. En el peor de los casos, como ocurre en el caso que se menciona en el Anexo I, los mineros informales pueden presentar documentación falsa para lograr la inscripción en el REINFO, realizar invasiones mineras o amenazar a los titulares mineros para obligarlos a suscribir contratos de cesión o explotación mineras con ellos.

El Decreto Supremo Nº03-2013-EM, que estableció precisiones en el marco del D.L. N ${ }^{\circ} 1105$, creó pasos que debían completarse en plazos distintos más pequeños y en un determinado orden. En el artículo 4 determinó que el primer requisito, la acreditación de titularidad, contrato de cesión o explotación sobre la concesión minera debía realizarse hasta el cinco de septiembre de 2013; el segundo, la acreditación de propiedad o autorización de uso del terreno superficial, hasta el dieciséis de septiembre de 2013; el tercero, la autorización de uso de aguas, hasta el veinticinco de septiembre de 2013; y por último, la probación del IGAC, hasta el cinco de octubre de 2013.

Lo mencionado en el párrafo anterior ya no se aplica, ahora se encuentra vigente el Proceso de Formalización Minera Integral que no incluyó dicha modalidad. Aunque los requisitos a acreditarse de ambos procesos sean distintos, la idea de establecer un orden específico y otorgarle una fecha límite diferente para cumplir con cada uno de los requisitos mejoraría el proceso de formalización minera; permitiría que los mineros informales tramiten los requisitos progresivamente para completarlos a tiempo, y las entidades competentes podrían controlar y verificar el estado en que se encuentran los respectivos trámites. 
Los mineros informales acreditan el requisito referente a la concesión minera suscribiendo un contrato de cesión o de explotación minera con el titular correspondiente, respetando el derecho de contratar de este último. La duración de dichos contratos la deciden las partes, debiendo tener un plazo mínimo de tres años para poder obtener los incentivos económicos regulados en el Decreto Legislativo $\mathrm{N}^{\circ} 1336$; a diferencia de la concesión minera, que cuando cumple con todas las obligaciones legales es irrevocable.

Los mineros informales así culminen la formalización minera y sean declarados mineros formales van a seguir encontrándose en la misma situación, el concesionario minero se encuentra en la facultad de pactar más adelante con quién considere conveniente o decidir explotar su concesión minera directamente.

Además, se debe tener en cuenta que la concesión minera obliga a que se trabaje, en caso se creen conflictos entre los concesionarios mineros y los mineros informales, por tener intereses opuestos, se dificulta el cumplimiento de dicha obligación legal. Lo mismo perjudica a los mineros informales, ya que una de las causales de exclusión del REINFO es no desarrollar actividad minera; para evitar conflictos que dificulten la formalización minera, se debe obligar a la participación de los titulares desde un inicio, así solo progresan los procesos cuyas partes así lo desean.

No se puede negar que la finalidad de la formalización de las actividades de la pequeña minería y la minería artesanal es de suma importancia debido a la importancia que los recursos naturales sean aprovechados de manera sostenible, de reducir los impactos que dañan el medio ambiente y mejorar las condiciones laborales, de salud y de seguridad minera; no obstante, es igual de importante que se respeten los derechos obtenidos por los sujetos de derecho del sector privado, teniendo en consideración que la concesión minera es un bien inmueble, y por ende goza de protección.

Teniendo en cuenta los derechos obtenidos por los concesionarios mineros, las obligaciones que deben cumplir para mantenerlos, las exhaustivas fiscalizaciones a las que son sometidos y las sumas considerables de dinero que aportan a las arcas del Estado, resulta inaudito que el PFMI permita que se los perjudique. 
La formalización minera permite la vulneración de los derechos de los concesionarios mineros, depende que no ocurra de la buena fe de los mineros informales durante la vigencia del proceso; pero, ¿Qué tanto se puede confiar en sujetos que antes de inscribirse en el REINFO desarrollaron durante años actividad minera ilegal, o qué de derivarse de los registros anteriores, no fueron capaces de lograr la formalización en un plazo mayor del que se les otorga ahora?

Así como el Proceso de Formalización Minera Integral crea la posibilidad para que los mineros informales puedan continuar realizando actividad minera, durante la vigencia de los tres años, sin la participación de los titulares de las concesiones mineras, los propietarios de los terrenos superficiales se encuentran en la misma posición, aunque de ellos dependa pactar o no con los mineros informales. Sin embargo, la presente tesis se centra en el primer caso, en el mundo del derecho minero.

\subsection{Análisis sobre la facultad otorgada a los mineros informales para desarrollar} actividad minera de explotación

Una consecuencia de la inscripción en el REINFO para los mineros informales es la obligación de desarrollar actividad minera respetando los parámetros del proceso durante la vigencia del mismo, y la de presentar los requisitos para culminar correctamente el PFMI. En otras palabras, permite la explotación minera por parte de los mineros informales que cuentan con una inscripción en el REINFO.

Para analizar dicha facultad otorgada a los mineros informales, primero se debe tener presente quién es el propietario de los yacimientos mineros y quién de los recursos minerales extraídos, además de cuales son los derechos con los que cuentan y en base a eso, quién es el sujeto que posee la facultad legal para explotar y disponer de los minerales.

De acuerdo al artículo 66 de la de la Constitución Política (1993), "Los recursos naturales, renovables y no renovables, son patrimonio de la Nación”, además, el Estado determina las condiciones para que se utilicen y se otorguen a los particulares. 
Específicamente, "los recursos minerales pertenecen al Estado, cuya propiedad es inalienable e imprescriptible"; su aprovechamiento "se realiza a través de la actividad empresarial del Estado y de los particulares, mediante el régimen de concesiones", conforme indica el artículo II del Título Preliminar del D.S. Nº14-92-EM.

El artículo 4 indica que "los recursos naturales mantenidos en su fuente, sean estos renovables o no renovables, son Patrimonio de la Nación”, y que los frutos y productos de esos recursos, "son del dominio de los titulares de los derechos concedidos sobre ellos" (Ley $\mathrm{N}^{\circ}$ 26821, 1997).

Para complementar lo mencionado en el párrafo anterior, el Código Civil en el artículo 890 define que: "Son frutos los provechos renovables que produce un bien, sin que se altere ni disminuya su sustancia"; en cuánto a los productos, el artículo 894 del mismo cuerpo legal indica que son "los provechos no renovables que se extraen de un bien". En el caso de los recursos minerales, son considerados productos porque su explotación altera y disminuye el bien original, gracias a la intervención humana (Decreto Legislativo $\left.\mathrm{N}^{\circ} 295,1984\right)$.

El Estado mediante la emisión de un acto administrativo como lo es la concesión minera, le concede a una persona natural o jurídica el derecho de explorar y explotar los recursos minerales en las zonas que le fueron concedidas; lo que genera que los minerales explotados y extraídos a la superficie, así como sus productos, pasen a ser parte de su propiedad.

Los seres humanos necesitan de distintos bienes para satisfacer sus necesidades, y cuándo ese interés es reconocido por el sistema jurídico entonces surge un derecho subjetivo (Gonzales Barrón, 2018, págs. 72-73). Además, como Morales Hervias señala en "La propiedad en las situaciones jurídicas subjetivas ${ }^{14}$ ", el derecho real es una posición o situación jurídica que tutela en forma directa el interés de las personas para la obtención

${ }^{14}$ MORALES, R. M. (2012). La propiedad en las situaciones jurídicas subjetivas. En Estudios sobre la propiedad. (pp. 91 - 110). LIMA. Fondo Editorial de la PUCP. 
del disfrute individual o de las distintas utilidades sobre una cosa, pero tal posición coexiste en el orden social (Gonzales Barrón, 2018, pág. 73).

Además, en el ámbito del derecho minero, (Baldeón Ríos, 2016) señala que la concesión minera:

Es un derecho real porque implica facultades del titular de la concesión en relación con una cosa: el depósito mineral, el yacimiento mineral o la mina. Estos atributos facultan al titular el uso, disfrute y propiedad del recurso mineral concedido y extraído o por extraerse; asimismo, la concesión puede ser objeto de disposición, hipoteca y cesión, tal como precisa el mismo artículo 23 de la Ley de Aprovechamiento Sostenible de los Recursos Naturales (págs. 245-246).

Asimismo, el artículo 23 de la Ley N 26821, afirma que: "La concesión otorga a su titular el derecho de uso y disfrute del recurso natural concedido y, en consecuencia, la propiedad de los frutos y productos a extraerse", además de señalar que es irrevocable siempre que el titular cumpla con las leyes especiales, en este caso, las leyes mineras.

Sobre la propiedad, la Constitución Política (1993) señala en el artículo 70: “El derecho de propiedad es inviolable. El Estado lo garantiza. Se ejerce en armonía con el bien común y dentro de los límites de ley”. "La propiedad es el poder jurídico que permite usar, disfrutar, disponer y reivindicar un bien. Debe ejercerse en armonía con el interés social y dentro de los límites de la ley”, según el artículo 923 del Código Civil.

Las definiciones de (Arias-Schreiber Pezet, 2001) complementan los términos mencionado en el anterior artículo:

- El derecho de usar: en virtud del cual el propietario utiliza el bien de conformidad con su naturaleza o destino. Este atributo presupone el derecho de poseer pues sin ella no puede beneficiarse del bien (pág. 230).

- El derecho de gozar o disfrutar: por el cual el dueño obtiene para sí el aprovechamiento del bien, se trate de sus frutos como de sus productos e incluye su consumo, cuando el bien es consumible (pág. 230).

- El derecho de disponer: es el más caracterizado porque el uso y el goce son actos de administración por cuya virtud el dueño tiene la libertad de disposición tanto 
material como jurídica, consumiéndolos, afectándolos, desmembrándolos o desprendiéndose de ellos a título oneroso o gratuito (pág. 230).

- El derecho de reivindicar: mediante el cual el propietario reclama su propiedad y evita que se intrometa un tercero ajeno a ese derecho (págs. 230-231).

El Código Civil determina que bienes con clasificados como inmuebles, específicamente en el numeral 8 del artículo 885 se encuentran "las concesiones mineras obtenidas por particulares". El artículo 9 del TUO de la LGM determina lo mismo, además de agregar que "la concesión minera es un bien inmueble distinto del predio donde se encuentra ubicada".

Con todo lo expuesto anteriormente, se buscó demostrar que diversos cuerpos legales reconocen que el titular de la concesión minera es quién posee el derecho para explorar y explotar dicha concesión, y que es el propietario de los recursos minerales si estos son extraídos, así como de sus frutos y productos; lo cual le otorga la facultad jurídica de usar, disfrutar, disponer y revindicar sobre sus bienes. Además, la concesión minera es un bien inmueble parte de su propiedad, y de manera irrevocable siempre y cuando cumpla con todas las obligaciones legales.

Ante este panorama, el PFMI permite que se inicie el proceso dentro de los territorios de las concesiones mineras, con el objetivo de que sus titulares suscriban un contrato minero con los mineros informales para que puedan culminar el proceso de formalización y ser declarados mineros formales, siempre que acrediten los demás requisitos legales. La inscripción en el REINFO inicia el proceso de formalización y una de sus consecuencias es permitir que los mineros informales desarrollen actividad minera.

Nuestra crítica se centra en los casos donde el Proceso de Formalización Minera Integral se encuentra vigente pero los concesionarios mineros todavía no han pactado con los mineros informales. En estos casos, los titulares de las concesiones mineras son los sujetos con derecho a la exploración y explotación de los minerales concedidos, como indica el artículo 9 del TUO de la LGM; y cuentan con la facultad legal de usar, disfrutar, disponer y reivindicar sobre dichos minerales. 
En otras palabras, el titular puede explotar directamente los minerales que se encuentran en su concesión minera y disfrutar así directamente de los beneficios, o puede disponer de ellos y pactar con un tercero mediante un contrato de cesión o de explotación minera para que los exploten estos últimos a cambio de una compensación.

El Proceso de Formalización Minera Integral crea una vía nueva para la explotación minera, protegiendo a los informales que no son los titulares mineros y que tampoco han conseguido el permiso de estos últimos, quiénes son los legítimos propietarios. Los concesionarios mineros se encuentran expuestos durante tres años, y ante un mal uso por parte de los mineros informales de las oportunidades que genera el proceso de formalización, pueden ver vulnerados sus derechos.

La formalización minera es un proceso relativamente nuevo, y como ocurre con la aplicación de una nueva legislación, se van creando problemas cuando entra en contacto con la realidad y de ahí surge la necesidad de solucionarlos, razón por la cual el Estado Peruano ha modificado continuamente la legislación: eliminando y simplificando requisitos y creado nuevos proceso de formalización, con sus respectivos registros.

Debido a ello no se puede afirmar que la legislación actual del Proceso de Formalización Minera Integral sea la definitiva y no pueda ser modificada de encontrarse algún error; por ello, ante las conclusiones del presente proceso de investigación pueden surgir ideas para algunas modificaciones necesarias. 


\section{CONCLUSIONES}

- El artículo 66 de la Constitución Política del Perú regula que: "Los recursos naturales, renovables y no renovables, son patrimonio de la Nación. El Estado es soberano en su aprovechamiento"; además, el artículo 67 del mismo cuerpo legal señala que el Estado "promueve el uso sostenible de sus recursos naturales" (1993). Mediante el régimen de concesiones, los minerales son otorgados a los particulares.

- El TUO de la Ley General de Minería regula en el artículo 9 que: "La concesión minera otorga a su titular el derecho a la exploración y explotación de los recursos minerales concedidos"; además, en su artículo 10 señala que: "La concesión minera otorga a su titular un derecho real". Siendo los minerales extraídos propiedad de su titular, así como sus frutos y productos -lo cual incluye lo que determina el artículo 923 del Código Civil "La propiedad es el poder jurídico que permite usar, disfrutar, disponer y reivindicar un bien"-, los titulares mineros o con quiénes pacten son los únicos sujetos que pueden explotar los recursos minerales que les fueron concedidos.

- Para realizar actividad minera de explotación no basta con tener una concesión minera, se necesita además obtener permisos, licencias, y autorizaciones relacionadas con la práctica de dicha actividad; por ejemplo, el Instrumento de Gestión Ambiental, ser propietario del terreno superficial o contar con el permiso de la totalidad de los propietarios de dicho terreno, el CIRA, el Derecho de uso de agua y la autorización para el inicio o reinicio de las actividades de exploración, desarrollo, preparación y explotación.

- La diferencia entre la minería informal y la minería ilegal radica en que la segunda actividad se desarrolla en áreas en las que no está permitido su ejercicio. Solo forman parte del Proceso de Formalización Minera Integral los sujetos inscritos en el REINFO, que son Pequeños Productores Mineros o Productores Mineros Artesanales.

- Mediante el Proceso de Formalización Minera Integral se determinan y administran los requisitos, plazos y procedimientos a ejecutar para que el minero informal inscrito en el REINFO pueda cumplir con la legislación vigente en cuanto al desarrollo de actividad minera. 
- El Proceso de Formalización Minera Integral sitúa al titular de la concesión minera en una posición vulnerable debido a que le otorga al minero informal la posibilidad de explotar los minerales que se localizan dentro de la concesión minera del primero, sin haber acreditado previamente un contrato de cesión o de explotación respecto de dicha concesión.

- Los titulares de las concesiones mineras se encuentran en una situación de desventaja dentro del Proceso de Formalización Minera Integral frente a los mineros informales, debido a que no se exige su participación desde el inicio del mencionado proceso.

- Los derechos de los titulares mineros que se pueden ver vulnerados con el desarrollo del Proceso de Formalización Minera Integral son: la propiedad -tanto al derecho a excluir a terceros como a su propiedad sobre los minerales extraídos-, a trabajar libremente, y si las autoridades competentes actúan aribitrariamente para promover el proceso de formalización, al debido proceso; además, se ve afectada la capacidad del concesionario minero de obtener ganancias económicas y competir con otros agentes económicos.

- Cuándo un minero informal culmina el Proceso de Formalización Minera Integral y es declarado un minero formal, se considera que ejerce actividad minera en cumplimiento de la legislación vigente; pero para ello, completó un proceso más sencillo en comparación con el que deben seguir los sujetos interesados dentro del régimen general o en el ámbito de la Pequeña Minería y la Minería Artesanal, debido a que estos últimos deben obtener diversos tipos de concesiones mineras, completar un Instrumento de Gestión Ambiental más complejo, realizar trámites ante un mayor número de entidades del Estado y realizar una mayor inversión de tiempo y de dinero.

- El Proceso de Formalización Minera Integral creado por el Decreto Legislativo No 1293 , el más reciente y vigente proceso, es distinto al proceso creado por el Decreto Legislativo $N^{o} 1105$ en el año 2012. A través de los años, se promulgaron numerosos Decretos Legislativos y Decretos Supremos que eliminaron, simplificaron y modificaron requisitos, crearon nuevos registros para la inscripción de los mineros informales y establecieron nuevos plazos de vigencia.

- El artículo 6 del D.L. No 1293 determina que: "El Proceso de Formalización Minera Integral tiene una vigencia de treinta y seis (36) meses"; el artículo 3 del Decreto Legislativo del No 1293 señala que: "Los requisitos a que se refiere el presente artículo, pueden ser tramitados o acreditados de manera simultánea", y el artículo 7 del D.S. N ${ }^{\circ}$ 018-2017-EM regula el compromiso a presentar los requisitos exigidos como una 
consecuencia a la inscripción en el REINFO. No determinan un orden específico para la acreditación de los requisitos ni exigen que se inicien los trámites con la mayor cerelidad posible; ante eso, en muchos casos el plazo de vigencia no es suficiente para los mineros informales y no son capacez de concluir el proceso a tiempo.

- En el REINFO, con vigencia hasta agosto de 2020, se pueden encontrar mineros informales que iniciaron los trámites para formalizarse en el año 2012; las ampliaciones de los plazos de vigencia de los procesos de formalización minera y la inclusión de los mineros informales de lo anteriores registros a los nuevos, sitúa a los concesionarios mineros en una posición vulnerable por más tiempo del inicialmente planeado y del necesario. Además, los mineros informales no se esfuerzan al máximo en culminar el Proceso de Formalización Minera Integral debido a que son conscientes de que es probable que les otorguen más oportunidades.

- Una consecuencia de la inscripción en el REINFO para los mineros informales es que desarrollen actividad minera, siempre en respeto de los compromisos y los requisitos a acreditar, según el artículo 7 del D.S. No 018-2017-EM. Dicha inscripción fue posible para los sujetos que cumplieron con lo regulado en los artículos 5 y 6 del mismo cuerpo legal - contar con una inscripción vigente en los registros anteriores o cumplir con la Resolución de Superintendencia No 013-2017-SUNAT-, lo cual no significó un filtro adecuado en relación a la posibilidad otorgada de realizar explotación minera.

- En nuestra opinión, el Estado Peruano prioriza el avance de la formalización minería integral y llegar a la meta de sus objetivos sobre garantizar el respeto de los derechos adquiridos por los titulares de las concesiones mineras, aún conociendo la dificultad que supone obtener una concesión minera y mantenerla vigente. Dicho proceso se ha ido simplificando cada vez más para volverlo más accesible de completar en beneficio de los mineros informales, en relación inversamente proporcional a la exposición de los derechos de los concesionarios mineros. 


\section{RECOMENDACIONES}

A continuación, detallaremos las recomendaciones:

- Se recomienda que el Proceso de Formalización Minera Integral motive a los titulares mineros a pactar con los mineros informales inscritos en el REINFO, ampliando los plazos de los beneficios económicos que se encuentran regulados en los artículos 18, 19 y 20 del Decreto Legislativo $N^{\circ} 1336$, los llamados “incentivos económicos".

- Se recomienda que el MINEM realice capacitaciones en favor de los mineros informales inscritos en el REINFO sobre cómo tramitar y acreditar los requisitos exigidos, y ante qué entidades del Estado, para así ayudarlos a culminar satisfactoriamente el proceso de formalización.

- Teniendo en cuenta que completar la inscripción en el registro correspondiente no supuso un filtro adecuado, se recomienda que se aumente la rigurosidad de la fiscalización de los actos de los mineros informales durante el trascurso del proceso, así como también de la explotación minera que realicen una vez que son declarados mineros formales.

- Considerando que ante un mal uso del proceso de formalización por parte de los mineros informales y que mediante la explotación minera pueden vulnerar los derechos de los titulares mineros, se recomienda se cree la obligación legal de contar con la participación de estos últimos desde el inicio del Proceso de Formalización Minera Integral y establecer una fecha límite para ello.

- Para incluir la participación del concesionario minero en el Proceso de Formalización Minera Integral, se sugiere establecer un plazo máximo de noventa (90) días hábiles para que el titular minero acredite ante la autoridad competente la existencia de actividad minera informal dentro del área de su concesión, además de manifestar mediante documentos, de así desearlo, su intención de ejercer la actividad de explotación de manera directa. El Proceso de Formalización Minera Integral se dará por finalizado y se ordenará la exclusión del minero informal del REINFO. 
- Se recomienda establecer plazos específicos para la acreditación de cada requisito del Proceso de Formalización Minera Integral dentro del plazo de vigencia de tres años regulado en el artículo 6 del D.L. No 1293; se propone regular un orden determinado, con una fecha límite para cada requisito y la obligación de acreditar un requisito para iniciar el trámite del siguiente, bajo responsabilidad de caer en una causal de exclusión del REINFO; de esa manera, los mineros informales podrán cumplir progresivamente con acreditar los requisitos obligatorios y culminar el proceso dentro de su vigencia.

- El orden recomendado para acreditar los requisitos del artículo 3 del Decreto Legislativo $\mathrm{N}^{\mathrm{o}} 1336$, siendo necesario completar uno para pasar al siguiente, es el que se señala a continuación: primero, la Acreditación de Titularidad, Contrato de Cesión o Contrato de Explotación respecto de la concesión minera; segundo, la Acreditación de Propiedad o Autorización de Uso del Terreno Superficial; tercero, la aprobación del IGAFOM o del IGAC según corresponda; y por último, la Autorización de inicio o reinicio de actividades mineras de explotación y/o beneficio de minerales y/o título de concesión de beneficio, que incluye la Presentación de Declaración Jurada de Inexistencia de restos arqueológicos.

- Se propone la modificación del artículo 13 del Decreto Supremo No 018-2017EM que regula las causales de exclusión del REINFO con la inclusión de las siguientes como nuevas causales: primero, que el titular minero manifieste a la autoridad competente su intención de realizar directamente la explotación minera dentro del derecho minero declarado en el REINFO; y segundo, que los mineros informales no cumplan con acreditar los requisitos para culminar el proceso de formalización en el orden establecido en la anterior recomendación y en respeto de los plazos específicos que se recomienda otorgar a cada requisito.

- Considerando la opción que en un futuro se amplíe el plazo de vigencia del Proceso de Formalización Minera Integral o se cree un nuevo proceso de formalización minera con un registro que permita la inscripción de los sujetos inscritos en el REINFO, se recomienda que no afecten dichas medidas a los mineros informales que no completen previamente el requisito de acreditar la titularidad, un contrato de cesión o de explotación en relación a la concesión minera. 
- Se recomienda capacitar a las autoridades mineras competentes del Proceso de Formalización Minera para que detecten posibles vulneraciones de los derechos de los titulares mineros; de esta manera se impulsará el desarrollo del proceso en beneficio de los mineros informales pero sin dejar de velar por los derechos adquiridos previamente por los concesionarios mineros.

- Debido a que el proceso de formalización protege a los mineros informales durante la vigencia del mismo, se recomienda determinar qué de probarse que realizan explotación minera de mala fe, ante la certeza de que no podrán pactar con el titular de la concesión minera o habiendo recibido ya una respuesta negativa, se les aplique la pena del artículo 307-A del Código Penal, que regula el delito de minería ilegal.

- Se sugiere al Estado fortalecer la lucha contra la minería ilegal a través de las actuaciones de las FEMA del Ministerio Público y los Juzgados Ambientales del Poder Judicial - y en apoyo de la PNP - en investigar, acusar y sancionar a las personas naturales y personas jurídicas que incurran en la comisión de los delitos ambientales y de minería ilegal; de esa manera, se incentivará la formalización minera al no existir otra opción viable. 


\section{REFERENCIAS}

Arias-Schreiber, M. (2001). Exegesis del Código Civil Peruano de 1984 (3. a ed.). Lima: Gaceta Jurídica.

Baldeón, J. (2016). Tratado de derecho minero peruano (1. ${ }^{a}$ ed.). Lima: Jurista Editores E.I.R.L.

Chávez, J.A. (2010). Manual de derecho ambiental (1. ${ }^{\text {a }}$ ed.). Lima: El Saber.

Código Orgánico Integral Penal. (10 de febrero de 2014). Recuperado de: www.justicia.gob.ec

Código Penal Federal, Últimas reformas publicadas DOF 21-06-2018. (14 de agosto de 1931). Recuperado de: https://mexico.justia.com

Constitución Política del Perú (1993). Recuperado del sitio de internet del Sistema peruano de información jurídica: http://spij.minjus.gob.pe

Contreras, C. (9 de febrero de 2018). Minería ilegal: en marzo operará el primer Juzgado Ambiental del Perú en Madre de Dios. La República. Recuperado de https://larepublica.pe/sociedad/1181994-mineria-ilegal-en-marzo-operara-elprimer-juzgado-ambiental-del-peru-en-madre-de-dios

Cucho Mendoza, H. U. (1999). Manual del Derecho de Minería en el Perú. Lima: Cultural Cuzco S.A.

Gamarra Barrantes, C. (2009). La concesión minera. Lima: Tinco. S.A.

García Delgado, F. (16 de noviembre de 2016). Minería ilegal arrasó 12.500 hectáreas desde el 2012. El Comercio. Recuperado de https://elcomercio.pe/lima/mineriailegal-arraso-12-500-hectareas-2012-148662

García Montufar, G., Franciskovic Ingunza, M. (1999). Derecho minero común. Lima: Gráfica Horizonte S.A.

Gonzales Barrón, G. (2018). Teoría General de la Propiedad y del Derecho Real (1. ${ }^{\text {a }}$ ed.). Lima: Gaceta Jurídica.

Decreto No 381, Modifica la estructura del Ministerio de Minas y Energía. (16 de febrero de 2012). Recuperado de: www.anm.gov.co

Decreto No 1073, Expide el Decreto Único Reglamentario del Sector Administrativo de Minas y Energía. (26 de mayo de 2015). Recuperado de: www.minminas.gov.co 
Decreto de Urgencia Nº08-2018, Amplían plazo para el pago del Derecho de Vigencia y de Penalidad a que se refieren los artículos 39 y 40 del Texto Único Ordenado de la Ley General de Minería, aprobado por Decreto Supremo No 014-92-EM, correspondientes al año 2018. (29 de junio de 2018). Recuperado de: http://spij.minjus.gob.pe

Decreto Legislativo $N^{o}$ 295, Código Civil. (25 de julio de 1984). Recuperado de: http://spij.minjus.gob.pe

Decreto Legislativo $N^{\circ}$ 635, Código Penal. (08 de abril de 1991). Recuperado de: http://spij.minjus.gob.pe

Decreto Legislativo $\mathrm{N}^{\mathrm{o}} 1100$, Decreto Legislativo que regula la interdicción de la minería ilegal en toda la República y establece medidas complementarias. (18 de febrero de 2012). Recuperado de: http://spij.minjus.gob.pe

Decreto Legislativo $\mathrm{N}^{\circ} 1102$, Decreto Legislativo que incorpora al Código Penal los delitos de minería ilegal. (29 de febrero de 2012). Recuperado de: http://spij.minjus.gob.pe

Decreto Legislativo $N^{\circ} 1105$, Decreto Legislativo que establece disposiciones para el proceso de formalización de las actividades de pequeña minería y minería artesanal. (19 de abril de 2012). Recuperado de: http://spij.minjus.gob.pe

Decreto Legislativo $N^{\circ} 1293$, Decreto Legislativo que declara de interés nacional la formalización de las actividades de la pequeña minería y minería artesanal. (30 de diciembre de 2016). Recuperado de: http://spij.minjus.gob.pe

Decreto Legislativo $N^{\circ} 1336$, Decreto Legislativo que establece disposiciones para el Proceso de Formalización Minera Integral. (6 de enero de 2017). Recuperado de: http://spij.minjus.gob.pe

Decreto Legislativo $\mathrm{N}^{\circ}$ 1351, Decreto Legislativo que modifica el Código Penal a fin de fortalecer la seguridad ciudadana. (7 de enero de 2017). Recuperado de: http://spij.minjus.gob.pe

Decreto Ley $\mathrm{N}^{\mathrm{o}}$ 10.426, Código Penal. (23 de agosto de 1972). Recuperado de: http://www.silep.gob.bo

Decreto Supremo No 014-92-EM, Texto Único Ordenado de la Ley General de Minería. (04 de junio de 1992). Recuperado de: http://spij.minjus.gob.pe

Decreto Supremo No 018-92-EM, Reglamento de Procedimientos Mineros. (8 de septiembre de 1992). Recuperado de: http://spij.minjus.gob.pe 
Decreto Supremo No 03-94-EM, Reglamento de diversos Títulos del Texto Único Ordenado de la Ley General de Minería. (14 de enero de 1994). Recuperado de: http://spij.minjus.gob.pe

Decreto Supremo No 33-94-EM, Modifican el Reglamento de Procedimientos Mineros.

(9 de julio de 1994). Recuperado de: http://spij.minjus.gob.pe

Decreto Supremo $N^{\circ}$ 013-2002-EM, Reglamento de la Ley de Formalización y Promoción de la Pequeña Minería y la Minería Artesanal. (21 de abril de 2002). Recuperado de: http://spij.minjus.gob.pe

Decreto Supremo No 084-2007-EM, Regulan el Sistema de Derechos Mineros y Catastro - SIDEMCAT y modifican normas reglamentarias del procedimiento minero para adecuarlas al proceso de regionalización. (20 de diciembre de 2007). Recuperado de: http://spij.minjus.gob.pe

Decreto Supremo No 059-2008-EM, Modifican el Reglamento de Procedimientos Mineros de la Ley General de Minería. (20 de noviembre de 2008). Recuperado de: http://spij.minjus.gob.pe

Decreto Supremo No 019-2009-MINAM, Reglamento de la Ley No 27446, Ley del Sistema Nacional de Evaluación de Impacto Ambiental. (25 de septiembre de 2009). Recuperado de: http://spij.minjus.gob.pe

Decreto Supremo No 001-2010-AG, Reglamento de la Ley No 29338, Ley de Recursos Hídricos. (24 de marzo de 2010). Recuperado de: http://spij.minjus.gob.pe

Decreto Supremo No 004-2012-MINAM, Aprueban Disposiciones Complementarias para el Instrumento de Gestión Ambiental Correctivo (IGAC), para la Formalización de Actividades de Pequeña Minería y Minería Artesanal en curso. (6 de septiembre de 2012). Recuperado de: http://spij.minjus.gob.pe

Decreto Supremo No 043-2012-EM, Establecen disposiciones complementarias a Decretos Legislativos $\mathrm{N}^{\circ} 1100$ y No 1105 e incorporan modificaciones al marco normativo minero. (30 de octubre de 2012). Recuperado de: http://spij.minjus.gob.pe

Decreto Supremo No 003-2013-EM, Establecen precisiones para la formalización minera a nivel nacional. (6 de febrero de 2013). Recuperado de: http://spij.minjus.gob.pe Decreto Supremo No 003-2013-MC, Aprueba el Procedimiento Simplificado para el Otorgamiento del Certificado de Inexistencia de Restos Arqueológicos (PROSIC) 
en el marco del Decreto Legislativo No 1105. (7 de marzo de 2013). Recuperado de: http://spij.minjus.gob.pe

Decreto Supremo No 054-2013-PCM, Aprueban disposiciones especiales para ejecución de procedimientos administrativos. (16 de mayo de 2013). Recuperado de: http://spij.minjus.gob.pe

Decreto Supremo N 029-2014-PCM, Aprueban Estrategia de Saneamiento de la Pequeña Minería y de la Minería Artesanal. (19 de abril de 2014). Recuperado de: http://spij.minjus.gob.pe

Decreto Supremo N ${ }^{\circ}$ 003-2014-MC, Reglamento de Intervenciones Arqueológicas. (4 de octubre de 2014). Recuperado de: http://spij.minjus.gob.pe

Decreto Supremo No 040-2014-EM, Reglamento de Protección y Gestión Ambiental para las Actividades de Explotación, Beneficio, Labor General, Transporte y Almacenamiento Minero. (12 de noviembre de 2014). Recuperado de: http://spij.minjus.gob.pe

Decreto Supremo No 005-2014-MC, Modifican los artículos 6, 8, 9, 10 y 13 del Decreto Supremo No 003-2013-MC que aprueba el Procedimiento Simplificado para el Otorgamiento del Certificado de Inexistencia de Restos Arqueológicos (PROSIC) en el marco del Decreto Legislativo $N^{\circ}$ 1105. (27 de diciembre de 2014). Recuperado de: http://spij.minjus.gob.pe

Decreto Supremo No 024-2016-EM, Reglamento de Seguridad y Salud Ocupacional en Minería. (28 de julio de 2016). Recuperado de: http://spij.minjus.gob.pe

Decreto Supremo No 018-2017-EM, Establecen disposiciones complementarias para la simplificación de requisitos y la obtención de incentivos económicos en el marco del Proceso de Formalización Minera Integral. (1 de junio de 2017). Recuperado de: http://spij.minjus.gob.pe

Decreto Supremo $\mathrm{N}^{\mathrm{o}}$ 037-2017-EM, Modifican el Reglamento de Procedimientos Mineros aprobado por Decreto Supremo N 018-92-EM. (31 de octubre de 2017). Recuperado de: http://spij.minjus.gob.pe

Decreto Supremo No 038-2017-EM, Establecen Disposiciones Reglamentarias para el Instrumento de Gestión Ambiental para la Formalización de Actividades de Pequeña Minería y Minería Artesanal. (1 de noviembre de 2017). Recuperado de: http://spij.minjus.gob.pe 
Decreto Supremo No 042-2017-EM, Reglamento de Protección Ambiental para las Actividades de Exploración Minera. (22 de diciembre de 2017). Recuperado de: http://spij.minjus.gob.pe

Forno Castro, X. (2009). El Título Minero como Acto Administrativo Habilitante. Revista de Derecho Administrativo, (8), 47-62.

Ipenza, C., Delgado, D. (diciembre de 2012). El Proceso de Formalización de la minería ilegal e informal. Revista Jurídica del Perú, Número(142), 61-70.

Ley Minera, Última reforma publicada DOF 26-06-2006. (26 de junio de 1992). Recuperado de: https://www.gob.mx/se/

Ley $\mathrm{N}^{\mathrm{o}}$ 45, Ley De Minera. (29 de enero de 2009). Recuperado de: http://www.competencias.gob.ec

Ley $\mathrm{N}^{\circ}$ 535, Ley de Minería y Metalurgia. (19 de mayo de 2014). Recuperado de: http://www.mineria.gob.bo

Ley $\mathrm{N}^{\mathrm{o}}$ 599, Código Penal. (24 de julio de 2000). Recuperado de: http://www.secretariasenado.gov.co

Ley $\mathrm{N}^{\mathrm{o}}$ 685, Código de Minas. (15 de agosto de 2001). Recuperado de: Www.minminas.gov.co

Ley $N^{\circ}$ 1382, Por el cual se modifica la Ley No 685 de 2001 Código de Minas. (9 de febrero de 2010). Recuperado de: www.anm.gov.co

Ley $N^{\circ}$ 1753, expide el Plan Nacional de Desarrollo 2014-2018. (9 de junio de 2015). Recuperado de: www.presidencia.gov.co

Ley No 11.179, Código Penal de la Nación Argentina. (21 de diciembre de 1984). Recuperado de: http://www.saij.gob.ar

Ley N $N^{\circ}$ 19.300, Ley sobre Bases Generales del Medio Ambiente. (09 de marzo de 1994). Recuperado de: www.leychile.cl

Ley $\mathrm{N}^{\circ} 26505$, Ley de la inversión privada en el desarrollo de las actividades económicas en las tierras del territorio nacional y de las comunidades campesinas y nativas. (18 de julio de 1995). Recuperado de: http://spij.minjus.gob.pe

Ley $\mathrm{N}^{\circ} 26821$, Ley Orgánica para el aprovechamiento sostenible de los recursos naturales (25 de junio de 1997). Recuperado de: http://spij.minjus.gob.pe

Ley $N^{o}$ 27446, Ley del Sistema Nacional de Evaluación del Impacto Ambiental. (23 de abril de 2001). Recuperado: http://spij.minjus.gob.pe 


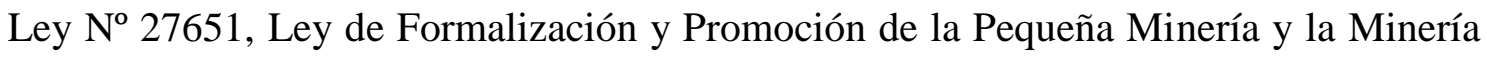
Artesanal (24 de enero de 2002). Recuperado de: http://spij.minjus.gob.pe

Ley No 28296, Ley General del Patrimonio Cultural de la Nación. (22 julio de 2004). Recuperado de: http://spij.minjus.gob.pe

Ley $N^{o}$ 28611, Ley General del Ambiente. (15 de octubre de 2005). Recuperado de: http://spij.minjus.gob.pe

Ley No 29338, Ley de Recursos Hídricos. (31 de marzo de 2009). Recuperado de: http://spij.minjus.gob.pe

Ley $\mathrm{N}^{\mathrm{o}} 30506$, Ley que delega en el Poder Ejecutivo la facultad de legislar en materia de reactivación económica y formalización, seguridad ciudadana, lucha contra la corrupción, agua y saneamiento y reorganización de Petroperú S.A. (9 de octubre de 2016). Recuperado de: http://spij.minjus.gob.pe

Lira Ovalle, S. (1998). Curso de derecho de minería: incluye prontuario con escritos y contratos de uso frecuente. Recuperado de: https://books.google.com.pe/books?id=AD23cvRmOysC\&dq=sistema+res+nulli us\&hl=es\&source $=$ gbs_navlinks_s

Ministerio de Agricultura y Riego (s.f.) Recursos naturales. Recuperado de: http://minagri.gob.pe/portal/marco-legal/58-sector-agrario/sector-agrario/287recursos-naturales

Ministerio de Minería iniciará proceso de formalización a mineros artesanales [editorial]. (21 de mayo de 2018). EcuadorInmediato. Recuperado de: http://www.ecuadorinmediato.com

Pothier, R.J. (1978). Tratado de las Obligaciones. Buenos Aires: Heliasta S.R.L.

Resolución de Superintendencia No 013-2017-SUNAT, Establecen forma de proporcionar información para el Registro Integral de Formalización Minera. (25 de enero de 2007). Recuperado de: http://spij.minjus.gob.pe

Resolución Jefatural № 007-2015-ANA, Aprueban Reglamento de Procedimientos Administrativos para el Otorgamiento de Derechos de Uso de Agua y de Autorización de Ejecución de Obras en Fuentes Naturales de Agua. (10 de enero de 2015). Recuperado de: http://spij.minjus.gob.pe

Resolución Ministerial No 289-2018-MEM/DM, Autorizan emisión de carné de identificación del minero en vías de formalización inscrito en el Registro Integral 
de Formalización Minera. (27 de julio de 2018). Recuperado de: http://spij.minjus.gob.pe

The Global Initiative Against Transnational Organized Crime. (2016). El Crimen Organizado y la Minería Ilegal de Oro en América Latina. Recuperado de: http://globalinitiative.net/organized-crime-and-illegally-mined-gold-in-latinamerica/

Torres, H., Velarde, R. (2013). Comentarios a la legislación para combatir la minería ilegal: antecedentes y perspectivas. Advocatus, Número(28), 423-437.

Torres, V. (2007). Minería artesanal y a gran escala en el Perú: el caso del oro (1. ${ }^{a}$ ed.). Lima: Ediciones Nova Print S.A.C. 


\section{BIBLIOGRAFÍA}

De La Puente Brunke, L. (2005). Legislación Ambiental en la Minería Peruana. Lima: Inst. de Estudios Energético Mineros.

Decreto $\mathrm{N}^{\circ} 76$, Aprueba Reglamento para aplicación de la ley no 20.235. (20 de junio de 2008). Recuperado de: http://www.minmineria.cl

Decreto $N^{\circ} 480$, Reglamenta las condiciones y requisitos para la celebración y ejecución de los subcontratos de formalización minera. (6 de marzo de 2014). Recuperado de: www.anm.gov.co

Decreto Legislativo $\mathrm{N}^{\mathrm{0}}$ 1101, Decreto Legislativo que establece medidas para el fortalecimiento de la fiscalización ambiental como mecanismo de lucha contra la minería ilegal. (29 de febrero de 2012). Recuperado de: http://spij.minjus.gob.pe

Decreto Legislativo $N^{\circ} 1106$, Decreto Legislativo de lucha eficaz contra el lavado de activos y otros delitos relacionados a la minería ilegal y crimen organizado. (19 de abril de 2012). Recuperado de: http://spij.minjus.gob.pe

Decreto Supremo No 021-2008-AG, Reglamento del Decreto Legislativo No 1081 que crea el Sistema Nacional de Recursos Hídricos. (25 de setiembre de 2008). Recuperado de: http://spij.minjus.gob.pe

Decreto Supremo Nº 075-2012-PCM, Crean Comisión Multisectorial Permanente con el objeto de realizar el seguimiento de las acciones del Gobierno frente a la minería ilegal y el desarrollo del proceso de formalización. (17 de julio de 2012). Recuperado de: http://spij.minjus.gob.pe

Decreto Supremo No 032-2013-EM, Fortalecen proceso de formalización de la pequeña minería y minería artesanal al amparo de lo dispuesto por el Decreto Legislativo $\mathrm{N}^{\mathrm{o}}$ 1105. (24 de agosto de 2013). Recuperado de: http://spij.minjus.gob.pe

Decreto Supremo 001-2015-EM, Aprueban disposiciones para procedimientos mineros que impulsen proyectos de inversión. (06 de enero de 2015). Recuperado de: http://spij.minjus.gob.pe

Galiano Gallardo, E. (2016). El Proceso de Formalización de las Actividades de pequeña minería y minería artesanal en Lima Metropolitana a partir del Decreto 
Legislativo $N^{\circ} 1105$ (Tesis para optar el grado de Magíster en Derecho de la Empresa con mención en Gestión Empresarial). Pontificia Universidad Católica del Perú.

Grandez, P. (noviembre de 2013). El Proceso de Formalización de la Pequeña Minería y la Minería Artesanal y sus implicancias en la interdicción de la minería ilegal. Revista Jurídica del Perú, número(153), 99-107.

Guerra Peñaloza, J., Guerra Sato, A.N. (1996). Elementos del derecho minero. Lima: Editorial Rhodas.

Ley $\mathrm{N}^{\circ} 1658$, Establecen disposiciones para la comercialización y el uso de mercurio en las diferentes actividades industriales del país, se fijan requisitos e incentivos para su reducción y eliminación y se dictan otras disposiciones. (15 de julio de 2013). Recuperado de: www.anm.gov.co

Ley $\mathrm{N}^{\circ}$ 1919, Código de Minería. (25 noviembre de 1886). Recuperado de: www.argentina.gob.ar

Ley $\mathrm{N}^{\mathrm{o}}$ 18248, Código de Minería. (14 de octubre de 1983). Recuperado de: http://www.minmineria.gob.cl

Ley $\mathrm{N}^{\circ} 29785$, Ley del derecho a la consulta previa a los pueblos indígenas u originarios, reconocido en el Convenio 169 de la Organización Internacional del Trabajo (OIT). (07 de setiembre de 2011). Recuperado de: http://spij.minjus.gob.pe

Ley $N^{\circ}$ 29968, Ley de creación del Servicio Nacional de Certificación Ambiental para las Inversiones Sostenibles (SENACE). (20 de diciembre de 2012). Recuperado de: http://spij.minjus.gob.pe

López Santos, D. (2009). Derecho minero. Lima: Ediciones Jurídicas.

Mendoza, P. (enero de 2016). Los delitos de minería ilegal y conexos: aspectos sustantivos y procesales. Gaceta Penal y Procesal Penal, Tomo(79), 307-339.

Resolución Ministerial No 473-2017-MEM-DM, Aprueban Formatos con el contenido detallado del Aspecto Correctivo y Preventivo del IGAFOM, y el Catálogo de Medidas Ambientales. (17 de noviembre de 2017). Recuperado de: http://spij.minjus.gob.pe

Resolución Suprema No 340-2013-PCM, Crean Comisión Multisectorial encargada de elaborar la propuesta de Estrategia de Saneamiento de la Pequeña Minería y de la Minería Artesanal. (22 de octubre de 2013). Recuperado de: http://spij.minjus.gob.pe 


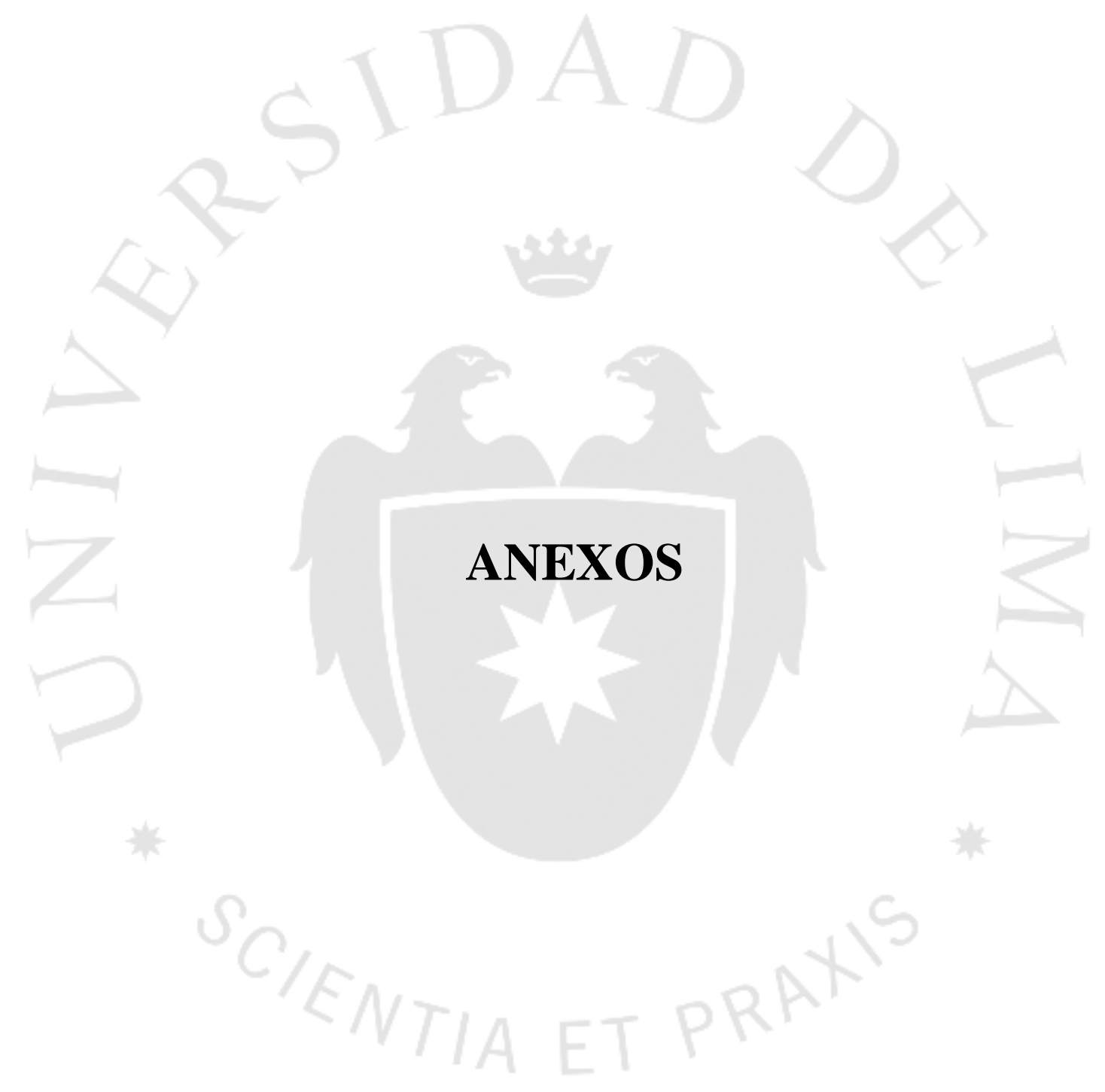




\section{ANEXO 1: CASO PRÁCTICO}

En el presente anexo se va a exponer el resumen de un caso donde el titular de una concesión minera viene teniendo problemas con los mineros informales inscritos en el Registro Integral de Formalización Minera. Se exponen los antecedentes, los hechos, la fundamentación jurídica presentada por la empresa minera y los derechos constitucionales inherentes a la concesión minera de su titular que han sido vulnerados. Como se va a poder apreciar, el Proceso de Formalización Minera Integral crea la situación ideal para que los mineros informales actúen de acuerdo a sus propios intereses.

\section{MATERIA: ACCIÓN DE AMPARO}

Al Señor Juez Constitucional de Lima

Demandante: Rossana Xxxxxx, Gerente General de la empresa minera XXXXX Demandado: Ministerio de Energía y Minas

Domiciliado en Av. De las Artes Sur N²60, San Borja.

\section{PETITORIO}

1.1. PRETENCIÓN PRINCIPAL: solicita se ordene el cese de la vulneración a los derechos constitucionales: a la PROPIEDAD, al DEBIDO PROCESO, a la LIBERTAD DE EMPRESA, al TRABAJO de la empresa XXXXXXXX XXXXXX S.A., y se repongan las cosas al estado anterior a la violación de sus derechos fundamentales.

1.2. PRETENSIÓN ACCESORIA: solicita que el Juzgado declare INAPICABLE para la empresa el Proceso de Formalización Minera Integral contenido en los Decretos Legislativos No 1336, No 1293 y el Decreto Supremo No 018-2017-EM, por ser normas legales inconstitucionales, para ese efecto solicitan se aplique el control difuso.

\section{FUNDAMENTOS DE HECHO}




\subsection{ANTECEDENTES}

A. Empiezan con los artículos referentes a los recursos minerales incluidos en la Constitución Política del Perú de 1993 y en el TUO de la Ley General de Minería, así como los relacionados a las actividades mineras, los mismos artículos que han sido incluidos en el trabajo de investigación.

B. El TUO de la Ley General de Minería establece las condiciones para el aprovechamiento de los recursos minerales depositados en el suelo y subsuelo del territorio nacional, la misma que se debe realizar exclusivamente mediante el sistema de concesiones.

C. En el presente caso, la empresa minera presentó un cuadro donde enumera las concesiones mineras de las que es titular, los nombres, el código único y el número de la Partida Registral. Dicho cuadro no ha sido copiado en el presente anexo por privacidad.

D. El primer párrafo del artículo 9 del TUO norma que "La concesión minera otorga a su titular el derecho a la exploración y explotación de los recursos minerales concedidos, que se encuentren dentro de un sólido de profundidad indefinida, limitado por planos verticales correspondientes a los lados de un cuadrado, rectángulo o poligonal cerrada, cuyos vértices están referidos a coordenadas Universal Transversal Mercator (UTM)”.

E. Al tener la empresa la condición de titular de las concesiones mineras antes mencionadas, está en condiciones de ejercer la actividad minera de explotación, que es definida por el artículo 8 del TUO como "la actividad de extracción de los minerales contenidos en un yacimiento".

F. Los minerales extraídos de concesiones mineras válidamente otorgadas y vigentes son de propiedad del titular minero, ejerciendo sobre los mismos los derechos inherentes a la propiedad como usar, disponer, disfrutar y reivindicar.

G. El artículo 4 del TUO de la Ley General de Minería norma que "Los productos minerales comprados a personas autorizadas para disponer de ellos, no son reivindicables. La compra hecha a persona no autorizada, sujeta al comprador a la responsabilidad correspondiente. El comprador está obligado a verificar el origen de las sustancias minerales".

H. La empresa es titular de las concesiones mineras detalladas, las mismas que fueron obtenidas previo cumplimiento del procedimiento ordinario normado en el 
TUO de la Ley General de Minería. Sobre los minerales contenidos en la concesión por aplicación de la Ley $\mathrm{N}^{\circ} 26821$ son los únicos propietarios, pudiendo disponer de los mismos según sus intereses.

\subsection{HECHOS}

A. La empresa tomó conocimiento de que los mineros informales iniciaron el Proceso de Formalización Minera Integral y presentaron información falsa ante la Autoridad Minera competente, indicando que realizan actividad minera de explotación dentro de sus concesiones mineras con autorización de parte de la empresa, hecho negado por esta última.

B. Se debe tener presente que la Unidad Económica Administrativa se constituyó mediante Resolución Directoral en el año 1988 con seis (6) concesiones mineras. Posteriormente, en el año 2011 mediante Resolución de Presidencia de INGEMMET se aprobó la inclusión de cinco (5) concesiones mineras más, dejando en un total de once (11) las concesiones mineras que conforman la UEA, propiedad todas de la empresa minera.

C. El artículo 83 del Decreto Supremo $\mathrm{N}^{\circ}$ 003-94-EM norma que "La Unidad Económica Administrativa (UEA) debe conformarse con concesiones mineras de un mismo titular de actividades mineras, incluidas las concesiones mineras cesionadas acreditadas con la respectiva constancia de inscripción del contrato de cesión en el Registro Público de Minería”.

D. La empresa mediante un escrito de fecha de presentación de Noviembre de 2017; un segundo escrito, de Enero de 2018; y un tercero, de Febrero de 2018, solicitó ante la Dirección General de Formalización Minera la ANULACIÓN del Registro Integral de Formalización MINERA (REINFO) de la totalidad de los mineros informales que declararon realizar actividad de explotación minera en sus concesiones mineras.

E. Se debe tener presente que por excepción el Decreto Supremo $\mathrm{N}^{\circ}$ 018-2017-EM permitió a personas que realizaban actividad minera ingresar al proceso de formalización minera previa acreditación de una serie de requisitos entre los que se encuentran "desarrollar actividad minera con una antigüedad no menor de 05 años". 
F. El artículo 3 del Decreto Legislativo $\mathrm{N}^{\circ} 1336$ determina los requisitos con los que deben cumplir los mineros informales para culminar satisfactoriamente el Proceso de Formalización Minera Integral, entre los que se encuentran la acreditación de titularidad, suscripción de contrato de cesión o contrato de explotación respecto de la concesión minera.

G. Los mineros informales presentaron documentos alegando la existencia de un contrato verbal con el representante de la empresa (el demandante) que les otorga la facultad de explotar los recursos minerales y les permite continuar con el Proceso de Formalización Minera Integral.

H. La empresa comunicó repetidas veces a la Dirección de Formalización Minera que no tiene la intención de suscribir acuerdo alguno con los mineros informales, manifestando expresamente que es su intención, ahora y en un futuro, realizar actividad minera de explotación de manera directa.

I. Los mineros informales alegan un contrato verbal entre el representante de la empresa (el demandante) y ellos, con el que fueron autorizados a ingresar y trabajar en los terrenos de las mencionadas concesiones mineras a cambio de un supuesto pago de regalías. La posición de la empresa es que presentaron documentos con información falsa de manera maliciosa e intencionada.

J. Los mineros informales no deberían contar con una inscripción vigente en el Registro Integral de Formalización Minera al no cumplir los requisitos exigidos en el Decreto Supremo $N^{\circ}$ 018-2017-EM, ante lo cual no deberían ser considerados como tal, sino mineros ilegales, bajo responsabilidad penal por la comisión de los delitos de minería ilegal.

\section{DERECHOS VULNERADOS}

\subsection{DERECHO A LA PROPIEDAD}

A. Este derecho esta consagrado en el articulo 70 de la Constitución Política del Estado, señala que: "el derecho de propiedad es inviolable. El Estado lo garantiza. Se ejerce en armonía con el bien común y dentro de los límites de ley. A nadie puede privarse de su propiedad sino, exclusivamente por causa de seguridad nacional o necesidad publica declarada por ley y previo pago en efectivo de indemnización justipreciada que incluya compensación por el eventual perjuicio”. 
Asimismo, el artículo 73 de la Constitución Política establece que los bienes de dominio público son inalienables e imprescriptibles, los bienes de uso público pueden ser concedidos a particulares conforme a ley, para su aprovechamiento económico. Además, el artículo 923 del Código Civil señala que: "la propiedad es el poder jurídico que permite usar, disfrutar, disponer y reivindicar un bien".

B. La empresa alega que el Ministerio de Energía y Minas a través de la Dirección General de Formalización Minera, en conjunto con el Gobierno Regional competente, a través de su Dirección Regional de Minería, están vulnerando los derechos de propiedad sobre las concesiones mineras antes mencionadas. Los mineros informales hacen mal uso del Decreto Legislativo $\mathrm{N}^{\circ} 1336$ al pretender continuar con el Proceso de Formalización Minera Integral sin la autorización del titular de la concesión minera, mediante la explotación de minerales de propiedad del titular y sabiendo que no es posible culminar dicho proceso sin acreditar ese requisito.

C. La empresa le solicita al Juzgado que haciendo uso del control difuso declare inaplicable y para este caso las normas jurídicas sobre el Proceso de Formalización Minera Integral, debido que no pueden ser válidos, legales ni constitucionales normas que afectan el derecho de propiedad. Es entendible su aplicación en terrenos eriazos del Estado pero no que impongan el proceso en terrenos que ya han sido concesionados a particulares.

D. La empresa asegura que los documentos contienen información falsa, que los mineros informales se quieren apropiar de los terrenos de las concesiones mineras y de toneladas de minerales ya explotados para así comercializarlos. Además, que perturban su posesión al ingresar repetidas veces sin consentimiento y con amenazas de hacerlo de nuevo, debido a que se encuentran respaldados por el proceso de formalización.

E. La empresa alega que a pesar de sus denuncias, las autoridades regionales y ministeriales (demandados) se prestan al juego de los demandados, actúan como cómplices y en vez de garantizar la vigencia plena de las concesiones mineras, dan trámite de forma irregular a los procesos administrativos de formalización minera, lo cual termina en la vulneración de su derecho a la propiedad.

\subsection{DERECHO AL DEBIDO PROCESO}


A. Este derecho se encuentra en el artículo 139 inciso 3 de la Constitución Política del Perú (1993): “Son principios y derechos de la función jurisdiccional: la observancia del debido proceso y la tutela jurisdiccional. Ninguna persona puede ser desviada de la jurisdicción predeterminada por la ley, ni sometida a procedimiento distinto de los previamente establecidos, ni juzgada por órganos jurisdiccionales de excepción ni por comisiones especiales creadas al efecto, cualquiera sea su denominación".

B. El Tribunal Constitucional ha establecido en (STC 04944-2011-PA/TC, 2012) que el derecho al debido proceso previsto por el artículo 139.3 de la Constitución Política del Perú: "Es aplicable no solo a nivel judicial sino también en sede administrativa e incluso entre particulares. Supone el cumplimiento de todas las garantías, requisitos y normas de orden público que deben observarse en las instancias procesales de todos los procedimientos, incluidos los administrativos y conflictos entre privados, a fin de que las personas estén en condiciones de defender adecuadamente sus derechos ante cualquier acto que pueda afectarlos".

C. Al tratar los antecedentes de los fundamentos de hecho se han podido evidenciar distintas vulneraciones al debido proceso que se dan en el Proceso de Formalización Minera Integral, evidenciando una actuación arbitraria e inconstitucional de la Dirección General de Formalización Minera del Ministerio de Energía y Minas y de la Dirección Regional de Minería del Gobierno Regional competente, que pretenden obligar al titular a que participe de dicho proceso de formalización.

D. La empresa alega que hay evidencia documental que en los años anteriores, específicamente desde el año 2011, ellos eran los únicos realizando actividad minera de explotación, lo cual es de conocimiento de las autoridades mineras, en ese caso, también sabían que los mineros informales no pueden suscribirse al REINFO sin completar el requisito que exige una antigüedad de 5 años mínimo de actividad minera, y aun así permitieron su inscripción en el Registro Integral de Formalización Minera.

\subsection{DERECHO A LA LIBERTAD DE EMPRESA}

A. Este derecho está regulado en el artículo 59 de la Constitución Política del Perú: "El Estado estimula la creación de riqueza y garantiza la libertad de trabajo y la 
libertad de empresa, comercio e industria. El ejercicio de estas libertades no debe ser lesivo a la moral, ni a la salud, ni a la seguridad públicas. El Estado brinda oportunidades de superación a los sectores que sufren cualquier desigualdad; en tal sentido, promueve las pequeñas empresas en todas sus modalidades”.

B. Al respecto, el Tribunal Constitucional ha precisado que: “...En primer lugar, la libertad de creación de empresa y de acceso al mercado significa libertad para emprender actividades económicas, en el sentido de libre fundación de empresas y concurrencia al mercado. En segundo término, la libertad de organización contiene la libre elección del objeto, nombre, domicilio, tipo de empresa o de sociedad mercantil, facultades a los administradores, políticas de precios, créditos y seguros, contratación de personal y política publicitaria, entre otros. En tercer lugar, también comprende la libertad de competencia. Y en último término, la libertad de disponer el cierre o cesación de las actividades de la misma cuando se considere oportuno (STC 0001-2005-PI/TC).

C. El objeto social de la empresa es la explotación y comercialización de recursos minerales, actividades que se ven afectadas con la actuación de los mineros informales del Proceso de Formalización Minera Integral, al ingresar y pretender realizar actividad minera dentro de las concesiones mineras en contra de la voluntad del titular.

D. Adicionalmente, estos hechos los ponen en desventaja respecto de otros agentes económicos y les dificulta competir con otras empresas mineras.

\subsection{DERECHO A LA LIBERTAD DE TRABAJO}

A. La Constitución Política del Perú de 1993 regula este derecho en el artículo 2 inciso 15: "Derechos fundamentales de la persona: Toda persona tiene derecho: 15. A trabajar libremente, con sujeción a ley.

B. El Tribunal Constitucional se ha pronunciado en torno a este derecho precisando: “... Que el derecho a la libertad de trabajo puede ser entendido como facultad de ejercer toda actividad que tenga como finalidad el sustento vital de la persona, siempre que ésta realice una labor racionalmente aceptada por la moral y salud pública y con el permiso del ente llamado por la ley a ejercer el control correspondiente (STC 2450-2007-PA/TC). 
C. La empresa alega que le es imposible trabajar libremente si de manera constante sufre invasiones mineras por parte de los mineros informales inscritos en el Registro Integral de Formalización Minera, además de amenazas constantes con tomar los recursos minerales a la fuerza.

D. Adicionalmente, alegan no poder trabajar libremente si la entidad demandada pretende desconocer sus derechos fundamentales, al aceptar el ingreso de dichos sujetos al Proceso de Formalización Minera Integral y permitir el desarrollo del mismo, sobre todo luego de las reiteradas manifestaciones por parte de la empresa minera de oponerse a la suscripción de un contrato de cesión o contrato de explotación minera con los mineros informales, como exige el requisito.

\section{CONTROL JUDICIAL DE LA CONSTITUCIONALIDAD DE LAS LEYES}

A. El control, revisión o examen de la constitucionalidad de las leyes consiste en comprobar si todas las leyes que integran el sistema jurídico son conformes a la constitución.

B. Todo juez es competente para INAPLICAR normas jurídicas en un caso concreto, la totalidad o parte de una ley. Lo que resuelva el Juez Constitucional solo tiene efectos interpartes.

\section{FUNDAMENTACIÓN JURÍDICA}

La pretensión se encuentra amparada en lo previsto en el Artículo 200 Inciso 2 de la Constitución Política del Estado y lo dispuesto en los artículos I, II, VI y VII del Título Preliminar y artículos 1, 2, 37, 42, 44, 45, 51 y los siguientes del Código Procesal Constitucional, artículos II y VI del Título Preliminar y artículos 923 y siguientes del Código Civil.

\section{INEXISTENCIA DE OTRAS VÍAS PROCEDIMENTALES IGUALMENTE SATISFACTORIAS AL AMPARO}

A. En el inciso 2 del artículo 5 del Código Procesal Constitucional se establece la improcedencia de la demanda de amparo cuando exista otra vía específica e igualmente satisfactoria. Para ello, se exige un análisis centrado en el caso concreto, 
B. El demandante alega que se encuentran ante un caso de tutela de urgencia en la medida que desde hace un mes se están produciendo las invasiones y amenazas de permanencia en los campamentos mineros, y que hace quince días fueron citados en la Dirección General de Formalización Minera del Ministerio de Energía y Minas para hacerles saber que se encuentra en trámite el Proceso de Formalización Minera Integral en el área de su concesión minera; lo que configura una amenaza cierta e inminente a los derechos constitucionales cuya tutela vienen invocando y también una clara vulneración de sus derechos. En este sentido, resulta necesario y urgente acudir a la vía del amparo pues es esa la vía idónea para restablecer los derechos constitucionales vulnerados.

C. Se obliga al magistrado a realizar un cuidadoso análisis: averiguar como requisito para admitir una acción de amparo, si los procedimientos regulares (sean judiciales o administrativos), resultan idóneos, suficientes, aptos o eficaces para el caso en concreto.

D. De interponerse un recurso de casación aproximadamente se tendría que esperar dos años y seis meses adicionales hasta la resolución final. En total, el promedio de duración de un proceso contencioso-administrativo, en todas sus etapas, es de cinco años y siete meses. Debido a que que la empresa considera no contar con tanto tiempo para proteger sus derechos, realiza una acción de amparo.

\section{AGOTAMIENTO DE LA VÍA PREVIA}

A. El amparo solo procede cuando se hayan agotado las vías previas, según lo establecido en el artículo 45 del Código Procesal Constitucional: "El amparo solo procede cuando se hayan agotado las vías previas. En caso de duda sobre el agotamiento de la vía previa se preferirá dar trámite a la demanda de amparo”.

B. En el presente caso, no se requiere del agotamiento de ninguna vía previa.

\section{PLAZO PARA LA INTERPOSICIÓN DEL AMPARO}

Los hecho mencionados ocurrieron en marzo de 2018 y la demanda de amparo fue presentada en mayo del presente año, razón por la cual se respetó el plazo de interposición de la demanda regulado en el artículo 44 del Código Procesal Constitucional.

\section{MEDIOS PROBATORIOS}


La empresa presentó como medios probatorios los siguientes documentos:
A. Títulos de concesión minera de sus diecisiete (17) derechos mineros.
B. Constancias de inscripción SUNARP de los 17 derechos mineros.
C. La Resolución de Aprobación del Estudio de Impacto Ambiental.
D. La resolución de aprobación del Plan de Cierre.
E. Formación de la Unidad Económica Administrativa. 
ANEXO 2: AUTO ADMISORIO

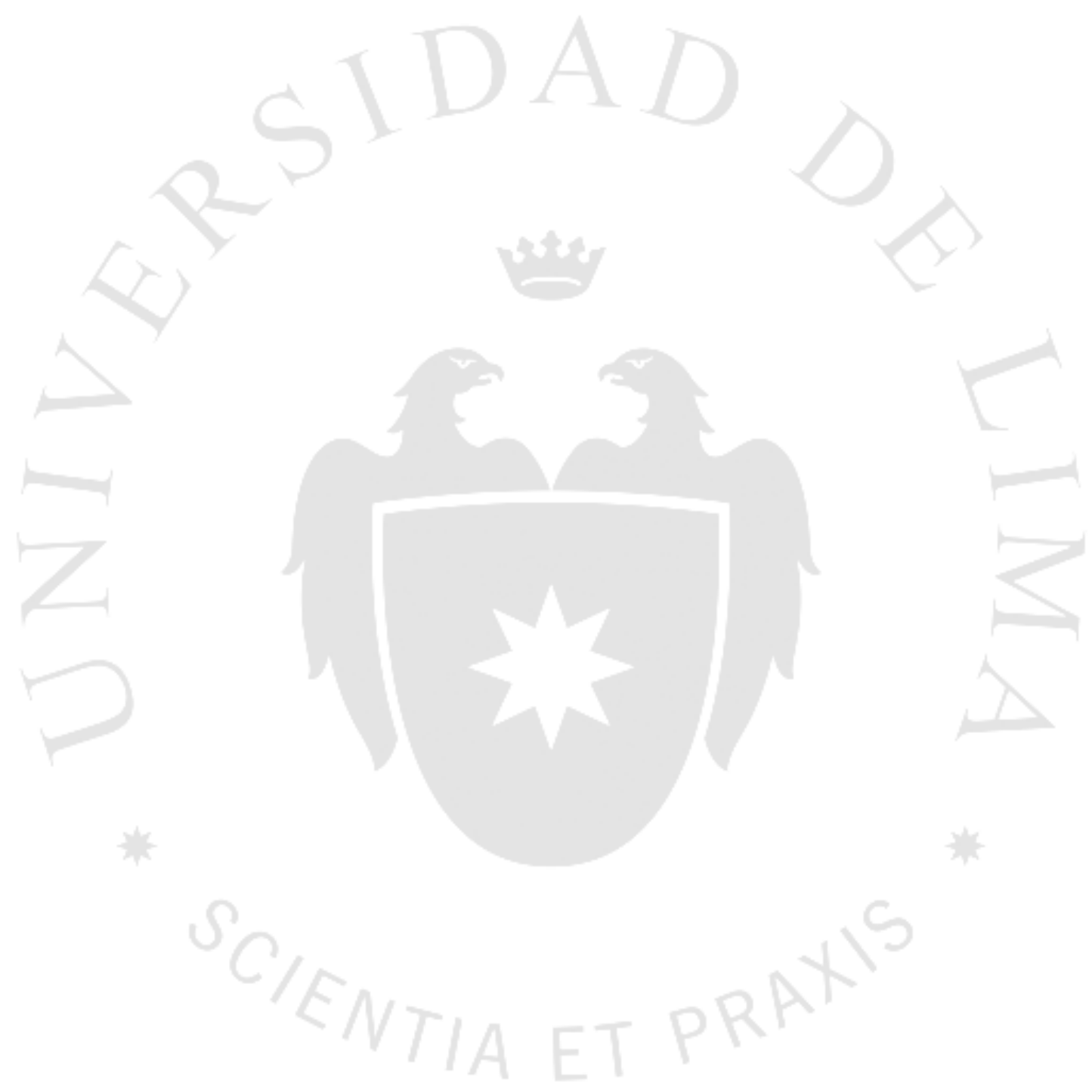




\section{EXPEDIENTE MATERIA \\ JUEZ \\ ESPECIALISTA \\ DEMANDADO \\ DEMANDANTE}
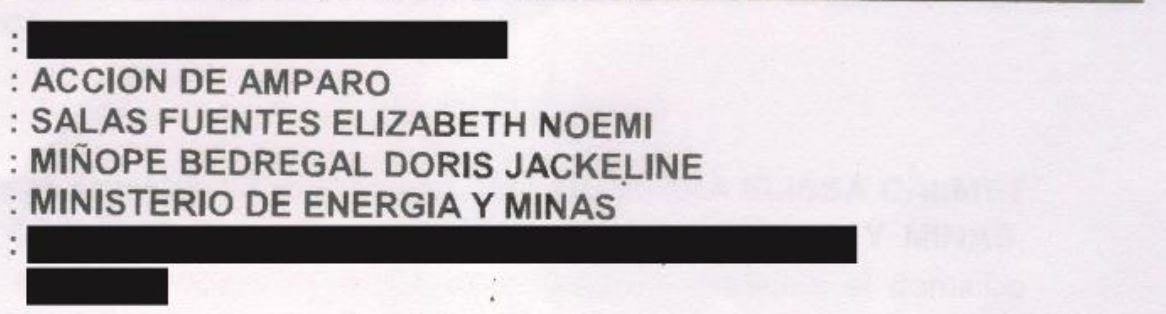

\section{AUTO ADMISORIO}

\section{RESOLUCIÓN NÚMERO UNO}

Lima, 10 de julio del 2018.-

AUTOS Y VISTOS: Con el escrito de demanda presentado con fecha 30 de mayo de 2018, recepcionado por este Despacho el 05 de junio de 2018; calificada en la fecha debido a la gran cantidad de demandas ingresadas a esta Judicatura; y CONSIDERANDO:

PRIMERO: Toda demanda para su admisión debe cumplir con los requisitos previstos en el artículo $42^{\circ}$ del Código Procesal Constitucion al, y en aplicación de lo dispuesto en el articulo IX del Título Preliminar de la misma norma se deben tener en cuenta los articulos $424^{\circ}$ y $425^{\circ}$ del Código Procesal Civil, ap robado por Resolución Ministerial N010-93-JUS, además de no hallarse incursa en ning una de las causales de improcedencia prevista en el artículo 5 del Código Procesal Constitucional y ello es así toda vez que, dada la naturaleza residual y urgente del proceso de amparo, la calificación de las demandas de este tipo tienen una tratamiento diferente a las demandas que se plantean en otras vias, como lo son los procesos en lo contencioso administrativo, la vía civil o comercial, y ello es así porque lo que no se quiere, es la desnaturalización del proceso, por tanto se debe tomar en cuenta lo dispuesto en el articulo $47^{\circ}$ del Código Procesal Consțitucional, en el que se contempla la posibilidad de rechazar liminalmente la demanda en caso se incurriera en cualquiera de las 10 causales previstas en el artículo $5^{\circ}$ del mismo códi go.

\footnotetext{
SEGUNDO: la empresa interpone demanda de amparo contra el Ministerio de

en representación de Energia y Minas, solicitando como pretensión principal se ordene al cese de la vulneración de los derechos constitucionales a la propiedad, al debido proceso, a la libertad de empresa, al trabajo de la empresa y como pretensión accesoria solicita la inaplicación del proceso de formalización minera contenido en los Decretos Legislativos $\mathrm{N}^{\circ} 1105, \mathrm{~N}^{\circ} 1336$ y $\mathrm{N}^{\circ} 1293$, Decreto Su premo $\mathrm{N}^{\circ}$ 018-2017 - EM, aplicándose el control difuso.
}

TERCERO: La recurrente manifiesta que la vulneración a los derechos constitucionales contra la empresa de la cual es accionista y Gerente General, han ocurrido desde el 20 de marzo de 2018 hasta la fecha, porque la autoridad minera les quiere imponer un proceso de formalización minera para favorecer a los mineros informales e ilegales, al pretender ejecutar procesos de formalización minera, por lo que considera que la resolución materia de la presente acción constitucional estaría vulnerando sus derechos constitucionales antes alegados; por lo que al advertiré un aparente acto que implica vulneración de derechos constitucionales la presente demanda deberá ser admitida a trámite. 
Que estando lo expuesto y estando que la presente demanda cumple con los requisitos señalados en los artículos $424^{\circ}$ y $425^{\circ} \mathrm{d}$ el Código Procesal Civil, norma aplicable en atención a lo dispuesto en el Artículo IX del Título Preliminar del Código Procesal Constitucional.

\section{SE RESUELVE:}

1. ADMITIR a trámite la demanda interpuesta por doña Por- ofrecidos los medios probatorios respectivos. Téngase presente el domicilio real, procesal y casilla electrónica.

2. CORRÁSE traslado de la demanda y de los anexos adjuntos al Procurador Publico del Ministerio de Energia y Minas, por el plazo de cinco días.

3. Al Primer Otrosi: Téngase presente los documentos que adjuntan; Al Sequndo Otrosí: Téngase por delegadas las facultades de representación favor de los letrados que se indica conforme a la norma invocada. Al Tercer Otrosi: Téngase presente. Notifíquese- 


\section{ANEXO 3: PROPUESTA NORMATIVA}

Bajo los criterios mencionados anteriormente en las recomendaciones tres, cuatro y cinco, se propone que se modifique la normativa actual y se introduzcan los siguientes artículos:

\section{Artículo 1: Pasos para la culminación del Proceso de Formalización Minera Integral}

Los requisitos para culminar el Proceso de Formalización Minera Integral que señala el el artículo 3 del Decreto Legislativo No 1336, se encuentran sujetos al cumplimiento de los siguientes plazos:

1. Los mineros informales que cuentan con una inscripción vigente del Registro Integral de Formalización Minera deberán cumplir con presentar la Acreditación de Titularidad, Contrato de Cesión o Contrato de Explotación respecto de la concesión minera, hasta el 8 de octubre de 2019.

2. Completado el paso anterior, los sujetos de formalización deberán cumplir con la Acreditación de Propiedad o Autorización de Uso del Terreno Superficial hasta el 7 de diciembre de 2019.

3. Completado el paso anterior, los sujetos de formalización deberán cumplir con presentar la aprobación del Instrumento de Gestión Ambiental para la Formalización de Actividades de Pequeña Minería y Minería Artesanal o del Instrumento de Gestión Ambiental Correctivo cuando corresponda, hasta el 8 de marzo de 2020.

Los sujetos de formalización deberán conseguir la Autorización de inicio/reinicio de actividades mineras de explotación y/o beneficio de minerales y/o título de concesión de beneficio, que incluye la presentación de la Declaración Jurada de Inexistencia de Restos Arqueológicos, emitida por la Dirección Regional de Energía y Minas correspondiente, o la que haga sus veces, conforme al artículo 29 del Decreto Supremo No 018-2017-EM y en respeto de la vigencia que señala el artículo 6 del Decreto Legislativo $\mathrm{N}^{\circ} 1293$; con su emisión concluye el Proceso de Formalización Minera Integral.

Los mencionados requisitos pueden ser tramitados simultáneamente pero deben acreditarse obligatoriamente según los pasos, el orden y los plazos establecidos en el 
presenten artículo, bajo responsabilidad de incurrir en una causal de exclusión del Registro Integral de Formalización Minera.

\section{Artículo 2: Oposición por parte del titular de la concesión minera}

El titular de una concesión minera, cuando sea ese el mismo derecho declarado por el minero informal para lograr la inscripción en el Registro Integral de Formalización Minera, y como consecuencia, desarrolle actividad de explotación dentro del marco del Proceso de Formalización Minera Integral, contará con un plazo máximo de noventa (90) días hábiles contados desde la fecha de entrada en vigencia de la presente norma, para que en caso sea su voluntad, manifestar ante la autoridad competente mediante un documento su intención de ejercer la explotación minera de manera directa.

Con la mencionada manifestación, el minero informal inscrito en el Registro Integral de Formalización Minera incurrirá en una causal de exclusión del REINFO; además, se dará por finalizado el Proceso de Formalización Minera Integral con respecto al minero informal o los mineros informales involucrados. 


\section{ANEXO 4: EL OTRO SENDERO}

El presente anexo describe brevemente el libro "El Otro Sendero: Una respuesta económica a la violencia" de Hernando de Soto, las conclusiones del autor y su relación con el Proceso de Formalización Minera Integral.

\section{Actividades informales}

El presente libro se centra en las actividades informales que se expandieron gracias a las migraciones de millones de personas del campo a la ciudad; estas personas se tuvieron que adaptar a una nueva realidad y sus acciones terminaron afectando a toda la sociedad.

Debido a las necesidades de las personas, los migrantes utilizan medios ilegales para satisfacer objetivos legales, como construir una casa, prestar un servicio o desarrollar una industria (pág. 42).

La primera actividad es la vivienda informal, en esta las personas han adquirido, habilitado y/o edificado sus vecindarios al margen o en contra de las disposiciones estatales, constituyendo de esa manera asentamientos informales (pág. 47).

El proceso de invasión comienza cuando un grupo de personas con el mismo interés se unen para planificar la invasión de un terreno del Estado o de un privado (pág. 50). Para que sea exitosa se debe crear, demarcar y repartir el asentamiento, así como designar funciones y asignar responsabilidades (pág. 52). Esta actividad tiene un carácter temporal, los informales esperan que alguna vez el gobierno les otorgue la propiedad definitivita (pág. 53).

La segunda actividad es el comercio informal, dentro de la cual existen dos modalidades: el comercio ambulatorio y los mercados informales, la segunda es la siguiente etapa del mismo fenómeno. A su vez, el comercio ambulatorio también se divide en dos: el comerciante que deambula por las calles y ofrece productos o servicios en una pequeña escala, y el comerciante que se encuentra en un lugar fijo en la vía pública y desde ahí vende productos o presta servicios (pág. 92). 
La tercera actividad es el transporte informal, que surgió por la necesidad de conectar a los barrios populares con el resto de la ciudad (pág. 127).

El transportista informal invade una ruta, el cual no es un bien físico como el terreno o la calle, sino un bien intangible, a determinar de acuerdo con la circulación y los deseos de viaje de la población (pág. 129). La realización de una invasión exitosa permite a los informales explotar las rutas antes que el estado les confiera reconocimiento alguno: relación jurídica extralegal (pág. 131).

\section{Costos de la formalidad}

Desde un punto de vista económico, hay dos momentos esenciales para que las personas evalúan su potencial relación con la formalidad: el acceso a la actividad y la permanencia dentro de la misma (pág. 166).

El primero, el costo de acceso, es en el que se incurre para completar las regulaciones gubernamentales, ante lo cual las personas con mayor capacidad económica pueden superarlos más fácilmente (pág. 181).

El segundo, el costo de permanencia, se prolonga durante el desenvolvimiento de la actividad económica, ante lo cual el ciudadano se encuentra en la obligación de cumplir con las leyes de la materia para conservar la legalidad (pág. 183).

\section{Costos de la informalidad}

En primer lugar, los costos de ilegalidad, abarcan los esfuerzos que realizan las empresas informales para evitar la sanción de las autoridades. Sanciones por no obtener licencias, no pagar impuestos o no obtener las autorizaciones legales; además de verse obligados a operar en dimensiones reducidas para no ser detectados y la imposibilidad de usar publicidad (pág. 187).

En segundo lugar, los costos de no tener una buena ley son los que sufren los informales por no contar con un derecho que les garantice y facilite la eficiencia de sus actividades económicas, es decir, una buena ley (pág. 192).

\section{Consecuencias de los costos de la formalidad para la economía peruana}

Los costos derivados de las actividades formales e informales tienen además otros efectos negativos sobre la economía en general, como son: la baja productividad, la disminución 
de la inversión, la ineficiente recaudación del sistema tributario, el aumento de las tarifas de los servicios públicos y limitaciones del progreso tecnológico (pág. 209).

Debido a que las leyes peruanas sofocan las actividades económicas, un gran número de personas ha optado por la informalidad (pág. 219).

\section{La buena ley}

No basta que una buena ley sea neutra y no induzca a las personas a ser informal, sino que debe hacer dos cosas; en primer lugar, proporcionar incentivos para aprovechar las oportunidades económicas y sociales que tiene el país; y segundo, facilitar la interdependencia entre hombres y recursos (pág. 219).

La buena ley garantiza el derecho de propiedad, el respeto por los contratos y la responsabilidad extracontractual, lo cual reduce la incertidumbre en las personas y los incentiva a invertir en actividades económicas a largo plazo (pág. 217). Aumentando así la formalidad en relación indirectamente proporcional a la informalidad.

\section{La tradición redistributiva}

La tradición redistributiva se entiende por utilizar el Derecho y formular leyes como un instrumento para repartir riquezas entre las esferas que tienen el poder económico y no con la intención de beneficiar a toda la población, ni de mejorar la accesibilidad a las actividades económicas.

Por ello, el Derecho va cambiando de acuerdo cambian las personas que se encuentran en dicha posición de poder, de ahí la falta de uniformidad y estabilidad en las leyes, y el aumento de la corrupción (pág. 227).

La presión para distribuir y redistribuir los recursos de la sociedad a través de la producción del Derecho ha ocasionado que las normas legales se hayan vuelto cada vez más engorrosas y complejas, convirtiéndose en la causa fundamental de la informalidad (pág. 230).

\section{El paralelo Mercantilista}

El mercantilismo Europeo significaba una economía políticamente administrada. La burocracia creía porque la razón de ser del Estado Mercantilista era distribuir riquezas de acuerdo a sus intereses fiscales y políticos, y así favorecer, desalentar o prohibir distintos tipos de actividades y agentes económicos (pág. 243). 
El sistema Europeo mercantilista y el sistema de Derecho redistributivo del Estado peruano comparten semejanzas: producción autoritaria de leyes, reglamentación engorrosa, aumento de los costos de transacción y acceso difícil a las actividades formales por parte de los ciudadanos sin poder o dinero (págs. 244-245).

Contrario al restringido acceso al mercado con el que cuentan las economías mercantilistas, se encuentra la economía de mercado, donde cualquier persona puede entrar al mercado, producir, distribuir o tramitar por cuenta propia y sin recurrir a terceros (pág. 246).

Los países Europeos que redujeron sus costos de transacción y sus normativas excesivas, además de la promulgación de la buena ley, lograron transitar hacia sistemas de mercado con un mínimo de violencia y un máximo de bienestar (pág. 158).

\section{Conclusiones del autor}

- Las instituciones legales se encuentran en crisis como resultado de la pérdida gradual de vigencia social frente a las incursiones de la informalidad en todos los ámbitos de la vida diaria (pág. 267).

- Los gobiernos Peruanos son "intransitivos", es decir, no mantienen una continuidad con los objetivos y proyectos nacionales debido a que siguen la tradición mercantilista de redistribuir riquezas entre las esferas de poder (pág. 269).

- Los individuos al no tener un acceso ordenado a la actividad productiva ni la protección de sus derechos individuales y de propiedad ante terceros, se rebelan contra la institucionalidad que las discrimina; en el mejor de los casos con la actividad informal, y en el peor con la criminalidad y la subversión (pág. 270).

- El progreso no resulta exclusivamente de la acción del Estado, por ende, la idea de que la voluntad de los gobernantes siempre se va a plasmar en la realidad conocida como "el voluntarismo centralista”, es una ilusión (pág. 273).

- El voluntarismo centralista fracasa en las sociedades modernas con economías de millones de personas; por ende, se deben abandonar las malas leyes del mercantilismo con las que se pretende gobernar cada cosa, cada transacción, cada propiedad; y sustituirlas, más bien, por instituciones legales eficientes que incentiven los fines deseados (pág. 274). 
- El objetivo es una economía de mercado moderna, para llegar ahí se deben cambiar las instituciones legales para así abaratar los costos de producir. Dar acceso a todos los ciudadanos para que integren la actividad económica, social y compitan en igualdad de condiciones sin importar su: origen, color, sexo, profesión u orientación política (pág. 280).

- La gran fuerza de un sistema de economía de mercado es que confía en la capacidad de trabajo y el ingenio del pueblo (pág. 280).

- Se deberían integrar a los formales e informales en un sistema económico-legal único. La integración significa hacer dos cosas: quitarle las restricciones improductivas al sistema legal e incorporar a todos bajo una nueva formalidad (pág. 283).

- Se deben simplificar las normas jurídicas, es decir, adoptar medidas que optimicen el funcionamiento de las instituciones legales existentes para que las partes duplicadas e inútiles de las normas existentes sean reducidas o eliminadas (pág. 283). La simplificación requiere que previamente se identifique el tipo de legislación que está causando daño (pág. 284).

- La simplificación implica reducir la burocracia, en lugar de cumplir con requisitos previos (ex ante) para realizar una acción, serán mas bien controlados después (ex post) para saber si están cumpliendo con la ley (pág. 284).

- Para que las autoridades se encuentren en contacto inmediato con la realidad y así puedan solucionar problemas, se deben traspasar las responsabilidades legislativas y administrativas del Gobierno Central a los Gobiernos Regionales y Locales, esto se entiende como descentralización (pág. 285).

- Es importante la desregulación, se entiende como el incremento de las responsabilidades y oportunidades de los particulares en ciertas áreas y la reducción del Estado en las mismas actividades (pág. 286).

- La mejor manera de producir normas jurídicas es cerciorarse de que sean necesarias y que sus beneficios excedan a sus costos potenciales, para lo cual habría que someterlo a consulta popular de la siguiente manera: que las autoridades publiquen sus proyectos de ley, y luego, en base a ellos recojan opiniones, sugerencias y objeciones de la población (pág. 289). 


\section{9. "El otro Sendero" y el Proceso de Formalización Minera Integral}

- Tanto el transporte, la vivienda y el comercio informal, como la minería ilegal e informal debilitan la influencia de las entidades del Estado y generan pérdidas económicas para el país debido a una menor recaudación tributaria.

- Las actividades informales que se mencionan en el presente libro generan violencia e inseguridad en la ciudad, debido a que los informales no cuentan con un derecho que proteja sus intereses económicos y su propiedad; asimismo, la minería ilegal e informal impactan negativamente en las comunidades dentro de sus zonas de influencia, promueve la trata de personas para la explotación sexual, el trabajo infantil e informal, y que no se respeten las condiciones de salud y seguridad minera.

- La actividad minera que se encuentra fuera del alcance de la legislación vigente se divide en dos: en primer lugar, la minería informal se desarrolla en zonas no prohibidas y dentro del Proceso de Formalización Minera Integral; y en segundo lugar, la minería ilegal se desarrolla en zonas prohibidas, o de no ser ese el caso, si no cumple con las exigencias administrativas, ambientales y sociales o en uso de equipo y maquinaria prohibida, como indica el artículo 2 del Decreto Legislativo $\mathrm{N}^{\mathrm{o}} 1105$.

- El libro hace referencia a los migrantes del campo a la ciudad, que ante la necesidad de satisfacer sus necesidades recurren al ejercicio de las actividades económicas informales, llamadas así porque operan fuera de la legislación vigente. En cambio, la minera informal se realiza en su mayoría en las zonas alejadas del país, donde el Estado tiene poca presencia y en busca de los grandes beneficios económicos que genera.

- El transporte informal, la construcción de viviendas informales y el comercio informal son actividades que realizan las personas en su día a día, que les proporcionan ganancias inmediatas para satisfacer sus necesidades básicas. En cambio, la minería ilegal e informal generan ganancias millonarias, sobre todo para los líderes de dicha actividad.

- La contaminación que genera al medio ambiente es de mayor consideración en la actividad minera ilegal e informal que en las actividades informales de vivienda, transporte o comercio, debido a los métodos que se utilizan para la explotación 
de minerales y los residuos mineros que se desechan, los cuales contienen una gran cantidad de químicos altamente tóxicos.

- Para el ejercicio de las actividades de transporte, vivienda y comercio, el tiempo que toma realizar los procedimientos administrativos para actuar bajo los parámetros de la ley - plazo que puede abarcar años- es excesivo en comparación a las posibilidades y necesidades de las personas. En cambio, los esfuerzos necesarios para desarrollar actividad minera legal son razonables debido al cuidado que se requiere para la explotación de recursos minerales, que antes de ser otorgados a los privados mediante el régimen de concesiones son Patrimonio de la Nación, y debido a los efectos que produce en el medio ambiente y las comunidades.

\section{Conclusiones}

- Entender el porqué de la informalidad en el Perú ayuda crear soluciones que cambien la realidad actual, en beneficio de los informales y del mismo Estado; sin embargo, no se puede justificar. Ayudar a los informales tiene un límite: donde comienza el respeto por los derechos de otras personas, como en este caso los titulares de las concesiones mineras.

- La complejidad de las normas jurídicas para lograr ejercer actividad minera formal no justifica la rebelión, ni la informalidad con la práctica de la minera informal, ni mucho menos la criminalidad con el desarrollo de la minería ilegal. Estas actividades no solo afectan los derechos del Estado por la incorrecta explotación de sus recursos minerales en terrenos eriazos; sino que al desarrollarse dentro de concesiones mineras otorgadas a privados, también los derechos correctamente adquiridos por sus titulares.

- La incapacidad del Estado para proteger el derecho de propiedad de los concesionarios mineros genera incertidumbre, como señala el autor Hernando de Soto, ese es el peor escenario posible para una actividad económica pues genera la disminución de las inversiones.

- Las normas referentes al proceso de formalización minera han sido simplificadas con el paso de los años hasta llegar al actual Proceso de Formalización Minera Integral, como recomienda el autor en beneficio de los informales; sin embargo, los titulares de las concesiones mineras se encuentran en una posición aún más 
perjudicial que antes. Además, se debe tener en cuenta que sin importar la simplificación del mencionado proceso, sin la voluntad del titular de la concesión minera de pactar con los mineros informales, el proceso no puede culminar satisfactoriamente.

- El autor recomienda pasar del cumplimiento de requisitos previos a la aprobación automática sometido a una fiscalización posterior, en el Proceso de Formalización Minera Integral se permite la explotación minera a los informales inscritos en el REINFO, bajo la promesa de acreditar los requisitos luego y así culminar el proceso. Sin embargo, si el propietario de los recursos minerales explotados es el titular de la concesión minera, su participación debería exigirse obligatoriamente desde el inicio; sobre todo teniendo en cuenta que de ver vulnerados sus derechos es muy complicado que reciban una indemnización.

- El desarrollo de actividad minera requiere de la obtención de varias licencias, autorizaciones, permisos y concesiones, para lo cual se deben completar procesos administrativos ante diversas entidades del Estado, dependiendo de la competencia de cada una una. Esto se debe a que el ejercicio de esta actividad incluye la explotación de recursos minerales - que antes eran parte del Patrimonio de la Nación-, el uso de otros recursos naturales como el agua, la contaminación del medio ambiente y la influencia en el desarrollo de las comunidades que se encuentran en su zona de influencia. Simplificar la normativa actual que regula la obtención de los requisitos obligatorios sería perjudicial para el correcto desarrollo de la actividad minera.

- El Estado no debe permitir bajo ninguna circunstancia que se vean vulnerados los derechos correctamente obtenidos por los titulares de las concesiones mineras, teniendo en cuenta que además de cumplir con la legislación minera vigente para obtenerlas, deben completar/continuamente una serie de obligaciones para mantener las concesiones mineras vigentes. Por ello, se debe tener especial cuidado con el desarrollo del Proceso de Formalización Minera cuando el titular de la concesión minera no sea el minero informal inscrito en el REINFO.

- Es un caso diferente cuando la zona en que se que se ejecuta el Proceso de Formalización Minera es un terreno eriazo del Estado, ahí se debe facilitar la culminación del mismo para que los recursos minerales dejen de ser explotados sin generar beneficios económicos al Estado, quien es el propietario. 